76

\title{
Cell cycle S-phase arrest drives cell extrusion
}

7

(1)

1

2

\section{Vivek K. Dwivedi $^{\alpha}$, Carlos Pardo-Pastor $^{\dagger}$, Rita Droste ${ }^{\alpha}$, Daniel P.}

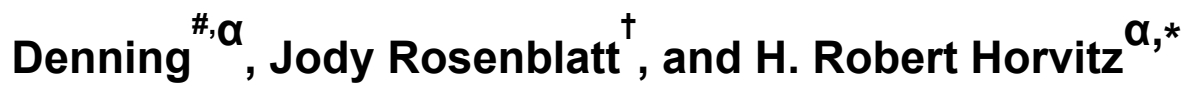

$\alpha_{\text {Howard Hughes Medical Institute, Department of Biology, Massachusetts }}$

Institute of Technology, Cambridge, MA 02139, USA

${ }^{\dagger}$ Randall Division of Cell and Molecular Biophysics, King’s College London, London SE1 1UL, UK

\#Novartis Institutes for BioMedical Research, Cambridge, MA 02139

*Correspondence: horvitz@mit.edu 


\section{SUMMARY}

30 Cell extrusion is a process of cell elimination in which a cell is squeezed

31 out from its tissue of origin. Extrusion occurs in organisms as diverse as

32 sponges, nematodes, insects, fish and mammals. Defective extrusion is linked to

33 many epithelial disorders, including cancer. Despite broad occurrence, cell-

34 intrinsic triggers of extrusion conserved across phyla are generally unknown. We

35 combined genome-wide genetic screens with live-imaging studies of $C$. elegans

36 embryos and mammalian epithelial cultures and found that S-phase arrest

37 induced extrusion in both. Cells extruded from C. elegans embryos exhibited S-

38 phase arrest, and RNAi treatments that specifically prevent S-phase entry or

39 arrest blocked cell extrusion. Pharmacological induction of S-phase arrest was

40 sufficient to promote cell extrusion from a canine epithelial monolayer. Thus, we

41 have discovered an evolutionarily conserved cell-cycle-dependent trigger of cell

42 extrusion. We suggest that S-phase-arrest induced cell extrusion plays a key role

43 in physiology and disease.

44

45 


\section{INTRODUCTION}

47 During development and homeostasis, cells are eliminated by a variety of

48 mechanisms. One such mechanism is cell extrusion, in which a cell is expelled

49 from a layer of cells while the continuity of the layer is maintained. Cell extrusion

50 has been observed in and studied using a wide variety of organisms, including

51 the sponge $H$. caerulea, $C$. elegans, $D$. melanogaster, zebrafish and mammals,

52 suggesting that cell extrusion is an evolutionarily conserved mechanism of

53 eliminating unnecessary or harmful cells (De Goeij et al., 2009; reviewed by

54 Gudipaty and Rosenblatt, 2017 and Ohsawa et al., 2018). Vertebrate epithelial

55 tissues use cell extrusion as the primary mode of cell elimination ( $\mathrm{Gu}$ and

56 Rosenblatt, 2012; Günther and Seyfert, 2018). Cell extrusion plays a key role in

57 epithelial defense mechanisms that remove oncogene-transformed cells from

58 epithelial layers (reviewed by Kajita and Fujita, 2015). Excessive cell extrusion

59 can produce epithelial layer breaches, like those observed in asthma and

60 Crohn's disease (Gudipaty and Rosenblatt, 2017). Decreased cell extrusion

61 leads to the formation of epithelial cell masses and confers resistance to cell

62 death (Eisenhoffer et al., 2012; Gu et al., 2015). Intestinal polyps, which can

63 develop into colon cancers, lack clearly identifiable cell extrusions (Eisenhoffer et

64 al., 2012), suggesting that extrusion might be important for the prevention of

65 polyps and intestinal cancers. Disruption and subversion of the cell-extrusion

66 process likely promotes tumor growth and metastasis in pancreatic, lung and

67 colon cancer (Gu et al., 2015). 
While several mechanisms of cell extrusion have been described for

69 Drosophila and vertebrates, these mechanisms have focused on the cell-cell

70 interactions and cellular contexts, such as crowding, topological defects, cell

71 competition, etc., that induce cell extrusion (reviewed by Fadul and Rosenblatt,

72 2018, Ohsawa et al., 2018). A cell-intrinsic trigger that can induce extrusion in

73 organisms of different phyla has not been identified.

74 C. elegans is an excellent organism for the study of evolutionarily

75 conserved mechanisms of cell elimination. The discovery of a conserved set of

76 genes regulating caspase-mediated apoptosis in $C$. elegans has been

77 fundamental to the understanding of programmed cell death in metazoa

78 (reviewed by Fuchs and Steller, 2011). Cell extrusion can eliminate cells fated for

79 death in C. elegans (Denning et al., 2012). Embryos with mutations in the

80 caspase-mediated apoptosis pathway, e.g. loss-of-function mutants of the

81 caspase gene ced-3, eliminate by extrusion a subset of cells that are otherwise

82 eliminated by caspase-mediated apoptosis and engulfment in wild-type embryos.

83 Denning et al. (2012) determined that the PAR-4 - PIG-1 (mammalian homologs

84 LKB1 - MELK) kinase cascade is required for cell extrusion by $C$. elegans ced-

85 3(If) embryos. However, LKB1 (mammalian homolog of PAR-4) was found to

86 prevent extrusion from mouse embryos (Krawchuk et al., 2015), indicating that

87 LKB1/PAR-4 is likely not a driver but a regulator of cell extrusion in nematodes

88 and mammals. No "caspase-equivalent" cell-intrinsic driver of cell extrusion is 89 known. 
90 To seek a conserved cell-intrinsic driver of extrusion, we first

91 comprehensively identified genes and pathways that control cell extrusion by $C$.

92 elegans and then tested the corresponding pathways for a role in mammalian cell

93 extrusion. Briefly, we performed a genome-wide RNAi screen for defective cell

94 extrusion by $C$. elegans and used confocal microscopy to analyze the effect of

95 RNAi against the identified genes on the cell extrusion process. From this

96 analysis, we found that cell extrusion by $C$. elegans requires cell-autonomous cell

97 cycle entry and subsequent S-phase arrest and that circumventing S-phase

98 arrest blocks extrusion. We then tested and confirmed that pharmacological

99 induction of S-phase arrest with hydroxyurea (HU) (Timson, 1975; Bianchi et al.,

100 1983) promotes cell extrusion of mammalian epithelial cells. We conclude that S-

101 phase arrest is a conserved cell-intrinsic trigger of cell extrusion in C. elegans

102 and mammals.

\section{RESULTS}

104 Genome-wide RNAi screen identified cell-cycle genes as candidate

105 regulators of cell extrusion

106 In wild-type C. elegans embryos, 131 cells are eliminated by caspase-

107 mediated apoptosis and engulfment. By contrast, in C. elegans ced-3 caspase

108 mutants, a few of the cells that would normally undergo programmed cell death

109 instead are extruded from the developing embryo (Denning et al., 2012). Of the

110 approximately six cells extruded from ced-3(If) embryos, the cell ABplpappap is

111 most frequently extruded (Denning et al., 2012 and unpublished). If extrusion

112 fails to occur, ABplpappap (or descendants of ABplpappap) survive(s) and 
113 differentiate(s) into one (or two) supernumerary excretory cell(s), producing

114 mutant animals with the two (or three)-excretory-cell (Tex) phenotype; by

115 contrast both wild-type and ced-3(If) animals have one excretory cell (Denning et

116 al., 2012; Figure 1A). Mutations that reduce ABplpappap extrusion and produce

117 the Tex phenotype also reduce the extrusion of other cells (Denning et al., 2012),

118 making the Tex phenotype a convenient marker for defective cell extrusion.

119 We performed a genome-wide RNAi screen for the Tex phenotype in ced-

$1203($ If $)$ animals expressing the GFP excretory-cell reporter $P_{p g p-12:: 4 x N L S:: G F P}$

121 (Figure 1B; Denning et al., 2012). We screened 11,511 RNAi clones (targeting

122 about $55 \%$ of the $\sim 20,000$ C. elegans genes by feeding (Rual et al., 2004)) and

123 found 30 clones targeting 27 unique genes that consistently produced a Tex

124 phenotype. Three RNAi clones identified genes previously reported to function in

125 cell extrusion, grp-1, arf-1.2 and arf-3 (Denning et al., 2012), confirming that this

126 RNAi screen could identify cell extrusion mutants. Unexpectedly, 10 of the RNAi

127 clones targeted genes that control cell-cycle progression (Figure 1C), suggesting

128 a possible role for the cell cycle in controlling cell extrusion.

129 We then tested a nearly complete set of $C$. elegans cell cycle genes for

130 functional roles in cell extrusion (van den Heuvel, 2005) using an RNAi library of

13161 publically available and, when necessary, newly generated clones with each

132 clone targeting a unique gene (Kamath et al., 2003; Rual et al., 2004; Materials

133 and Methods). We found that RNAi against four additional cell cycle genes

134 produced a Tex phenotype (Figure 1C, Supplemental Table 1). 
135 Most of the 14 cell-cycle genes we identified are well-characterized

136 regulators of S-phase entry and progression. These genes include cdc-25.2,

137 which encodes a homolog of the CDK-activating phosphatase CDC25 (Lee et al.,

138 2016); $c d k-1$ and $c d k-2$, which encode homologs of CDK1 and CDK2,

139 respectively (Boxem, 2006); cye-1 and cya-1, which encode homologs of S-

140 phase cyclins E and A, respectively (Fay and Han, 2000; Kreutzer et al., 1995);

141 and $p s f-1, p s f-2$ and $p s f-3$, which encode homologs of pre-replicative and

142 replicative complex components PSF1, PSF2 and PSF3, respectively (Ossareh-

143 Nazari et al., 2016; Figure 1C). All of these cell cycle genes with S-phase

144 function are required for $C$. elegans viability. However, it is unlikely that a general

145 reduction in embryonic fitness causes the Tex phenotype, as RNAi against

146 essential genes involved in other phases of the cell cycle (e.g., metaphase-to-

147 anaphase transition genes mat-1, mat-2, etc. (reviewed by Yeong, 2004)) or

148 those involved in transcription (e.g., cdk-7 and cdk-9 (Wallenfang and Seydoux,

149 2002; Bowman et al., 2013)) did not produce the Tex phenotype despite

150 producing extensive lethality (Supplemental Table 1). Furthermore, as with RNAi

151 targeting pig-1 or other genes generally required for cell extrusion (Denning et

152 al., 2012), RNAi against 13 of the 14 identified cell cycle genes produced the Tex

153 phenotype in ced-3(If) mutants but not in wild-type animals (Supplemental Table

154 2). Altogether, we found that defects in S-phase entry and progression are

155 specifically associated with a synthetic ced-3-dependent Tex phenotype,

156 suggesting a role for these cell-cycle genes in promoting cell extrusion.

\section{S-phase entry genes function to promote cell extrusion}


158 Whereas defects in the extrusion of ABplpappap cause the Tex

159 phenotype, it is possible that the supernumerary excretory cell(s) of some

160 mutants could arise from other cell lineages. To directly determine whether

161 genes functioning in S-phase entry are important for cell extrusion, we used time-

162 lapse confocal microscopy to monitor the extrusion of ABplpappap from ced-3(If)

163 embryos deficient in cye-1 or cdk-2. To assess extrusion events, we imaged live

164 embryos with ABplpappap in focus over a 50-minute period ending at the

165 completion of ventral enclosure, when epidermal cells meet at the ventral midline

166 following a dorsolateral migration; ventral enclosure coincides with the cell

167 extrusion that occurs in ced-3(If) embryos (Denning et al., 2012). For clarity, we

168 refer below to embryos from ced-3(If) parents treated with RNAi against a gene,

169 say gene-x, as "gene-x(RNAi) embryos" and to embryos from ced-3(If) parents

170 treated with RNAi against the empty vector as "control embryos."

171 In control embryos, cells neighboring ABplpappap on the ventral surface

172 gradually disappeared from view until ABplpappap was left completely isolated

173 (Figure 2A, Movie 1), indicating that ABplpappap had been extruded from the

174 embryo. By comparison, in cye-1(RNAi) embryos (Figure 2B, Movie 2) or cdk-

175 2(RNAi) embryos (Figure 2C, Movie 3), ABplpappap was surrounded by cells

176 throughout the imaging period and hence remained within the embryo, failing to

177 detach. Using dorso-ventral confocal sections from the live embryo imaging, we

178 reconstructed sagittal views of the embryos during ventral enclosure. These

179 views confirmed that ABplpappap was extruded ventrally from 10 of 11 control

180 embryos (Figure 2D, Supplemental Figure 1), whereas ABplpappap failed to 
181 detach and was incorporated into the body of cye-1(RNAi) embryos (11 of 11

182 embryos; Figure 2E, Supplemental Figure 2) or cdk-2(RNAi) embryos (10 of 11

183 embryos; Figure 2F, Supplemental Figure 3). These findings demonstrate that

184 the S-phase entry genes cye-1 and cdk-2 are required for ABplpappap extrusion

185 in ced-3 embryos.

186 Entry into S phase is required for and precedes cell extrusion

187 Since genes that promote S-phase entry are required for ABplpappap

188 extrusion, we tested if cells that undergo extrusion enter $\mathrm{S}$ phase. We used a

189 previously characterized reporter transgene that expresses a truncated human

190 DNA Helicase B (tDHB)-GFP fusion protein optimized for expression in $C$.

191 elegans and that changes its intracellular location in response to CDK1 and

192 CDK2 activity (van Rijnberk et al., 2017; Spencer et al., 2013). tDHB-GFP is

193 enriched in the nuclei of quiescent or post-mitotic cells, whereas it exhibits an

194 increasing cytoplasmic bias as cells progress from S-phase through mitosis

195 (Figure 3A; Spencer et al., 2013). In control embryos, tDHB-GFP was mostly

196 absent from the ABplpappap nucleus (10 of 10 embryos) both before ventral

197 enclosure (Figure 3B) and as it was extruded (Figure 3E), indicating that

198 ABplpappap entered S phase prior to its extrusion during the period of ventral

199 enclosure. Cells extruded from other sites of the embryo also displayed low

200 levels of nuclear tDHB-GFP (Figures 3I-L). By contrast, in cye-1(RNAi) embryos

201 (Figures 3C, 3F) or cdk-2(RNAi) embryos (Figures 3D, 3G) the ABplpappap

202 nucleus scored positive for the tDHB-GFP fusion protein during the period 203 around ventral enclosure (10 of 10 embryos each for each RNAi treatment), 
204 suggesting that RNAi against these genes prevented both the entry of

205 ABplpappap into S-phase and its extrusion. Quantification of the nuclear-to-

206 cytoplasmic ratio of tDHB-GFP fluorescence intensity in ABplpappap in control,

207 cye-1(RNAi) and cdk-2(RNAi) embryos at varying stages with respect to ventral

208 enclosure confirmed these observations (Figure $3 \mathrm{H}$ ). Some cells were still

209 extruded in cye-1(RNAi) and cdk-2(RNAi) embryos, likely reflecting incomplete

210 inhibition of gene function by RNAi. Consistently, such cells displayed low levels

211 of nuclear tDHB-GFP, indicating that those cells entered the cell cycle

212 (Supplemental Figure 4). Thus, cell-cycle entry appears to be a functionally

213 critical step in the process of cell extrusion.

214 To define more precisely the cell-cycle phase that facilitates cell extrusion,

215 we used a second reporter transgene (GFP::PCN-1), which expresses an N-

216 terminal translational fusion of GFP to the $C$. elegans homolog of the DNA 217 replication processivity factor PCNA (Brauchle et al., 2003). PCNA in mammalian

218 cells and early C. elegans embryonic cells exhibits a punctate, sub-nuclear 219 localization only during S-phase (Figure 4A; Brauchle et al., 2003; Zerjatke et al., 220 2017). The localization pattern of GFP::PCN-1 in cell cycles of cells close to

221 ABplpappap on the embryonic ventral surface matched that described for early 222 embryonic cells and contrasted with the continuous accumulation of GFP::PCN-1

223 observed during the C. elegans germline cell cycle (Supplemental Figure 5;

224 Movie 4; Brauchle et al., 2003; Kocsisova et al., 2018). We found that in control

225 embryos GFP::PCN-1 was localized in bright sub-nuclear foci in ABplpappap

226 immediately prior to the initiation of ventral enclosure, indicating that this cell was 
227 in S phase (5 of 5 embryos) (Figure 4B). By contrast, ABplpappap showed a

228 diffuse nuclear localization of GFP::PCN-1 in cye-1(RNAi) (Figure 4C, 4F) and

229 cdk-2(RNAi) (Figure 4D, 4G) embryos, both before (5 of 5 embryos each) and

230 after ventral enclosure (5 of 5 embryos each), indicating a failure to enter the cell

231 cycle. We conclude that cells to be extruded must enter $\mathrm{S}$ phase for extrusion to

232 occur and that blocking S-phase entry prevents cell extrusion.

233 Extruding cells exhibit an arrested $\mathbf{S}$ phase and experience replication

234 stress

235 Given that cells required cell-cycle entry for extrusion, we examined the

236 extent of cell-cycle progression in these cells as they were extruded. In control

237 embryos, we found that GFP::PCN-1 was localized in bright sub-nuclear foci in

238 ABplpappap both before (5 of 5 embryos) and after extrusion ( 5 of 5 embryos)

239 (Figure 4B, 4E), indicating that ABplpappap entered but did not exit S phase. We

240 observed no significant changes of GFP::PCN-1 localization in ABplpappap up to

241 and after its extrusion over a period of 35 min (Figure $4 \mathrm{H}$ ), indicating that it

242 remained arrested in S phase. A second unidentified extruding cell showed a

243 similarly unchanging GFP::PCN-1 localization pattern (Figure 4H). To determine

244 if the S-phase arrest observed in ABplpappap and the other extruding cell is a

245 general feature of cell extrusion, we examined other extruded cells in the

246 embryo. Nearly all cells extruded by ced-3(If) embryos displayed bright sub-

247 nuclear foci of GFP::PCN-1, consistent with an arrested S phase in these cells

248 (Figures 4H-J). 
Arrest of DNA replication during $S$ phase can occur as a result of

250 replication stress, which can arise for many different reasons (reviewed by

251 Zeman and Cimprich, 2014). Replication stress triggers the replication stress

252 response, which stabilizes stalled replication forks, halts cell-cycle progression

253 and prevents further firing of replication origins (reviewed by Zeman and

254 Cimprich, 2014). As cells undergoing extrusion are arrested in S-phase, we

255 asked if triggering the replication stress response was important for extrusion.

256 Core components of the replication stress response pathway in C. elegans and

257 other metazoans include ATR, Chk1, Rad17, Rad9, Rad1, Hus1, Replication

258 Protein A, TopBP1, Timeless, Tipin and Claspin proteins (Stevens et al., 2016;

259 Yazinski and Zou, 2016). RNAi against 7 of the 11 C. elegans genes encoding

260 these core components of the replication-stress checkpoint (atl-1, chk-1, hpr-9,

261 mus-101, tim-1, tipn-1 and clsp-1) produced a Tex phenotype in ced-3(If) animals

262 (Figure 1C, Figure 4L), indicating an involvement of replication stress response in

263 cell extrusion. These findings suggest that the replication stresses underlying the

264 S-phase arrest in extruding cells trigger the replication stress response, which

265 promotes cell extrusion.

266 Bypassing S-phase arrest and completing the cell cycle prevents cell 267 extrusion

268 After determining that S-phase arrest is a key feature of cell extrusion, we 269 asked whether the previously identified C. elegans cell extrusion regulators pig-1 270 (homolog of the mammalian kinase gene MELK) and grp-1 (homolog of the 271 mammalian ARF GEF gene CYTH3) (Denning et al., 2012) also play a role in 
272 producing this S-phase arrest. We monitored the fate of ABplpappap in pig-

273 1(RNAi) embryos by time-lapse confocal microscopy. Strikingly, we found that

274 instead of undergoing S-phase arrest, ABplpappap completed the cell cycle and

275 divided before ventral enclosure in these embryos (Figure 5A; Movie 5). By

276 examining virtual lateral sections, we found that instead of undergoing extrusion,

277 as in the case of control embryos (Figure 5B), ABplpappap in pig-1(RNAi)

278 embryos divided to generate daughters that were not extruded (5 of 6 embryos)

279 (Figure 5C). The same fate of ABplpappap was observed in grp-1(RNAi)

280 embryos (5 of 5 embryos) (Figure 5D). These findings indicate that in addition to

281 the genes cye-1 and cdk-2, the genes pig-1 and grp-1 are required to produce

282 the S-phase arrest that precedes cell extrusion.

283 Next, we investigated why ABplpappap completed the cell cycle in pig-

$2841(R N A i)$ and grp-1(RNAi) embryos. In several cell lineages, such as the $Q$

285 neuroblast cell lineage, the genes pig-1 and grp-1 are required for unequal cell

286 divisions that generate apoptotic cells (Cordes et al., 2006; Teuliere et al., 2014).

287 Consistent with their function in controlling unequal cell division, RNAi against

288 each of the genes pig-1 and grp-1 perturbed the ratio of ABplpappap's size to

289 that of its sister and generated an abnormally large ABplpappap (Figures 5E,F;

290 Supplemental Figures 6A,D,E). These findings indicated that unequal cell

291 division plays an important role in producing the S-phase arrest that precedes

292 cell extrusion. However, despite the requirement for cye-1 and cdk-2 to produce

293 this S-phase arrest (Figures 3B, 4B), RNAi against cye-1 or cdk-2 did not affect

294 unequal cell division. Neither the size of ABplpappap relative to that of its sister 
295 nor the absolute size of ABplpappap showed a difference among cye-1(RNAi),

296 cdk-2(RNAi) and control embryos (Figures 5G,H; Supplemental Figure 6A,B,C).

297 Together, our data indicate that genes required for cell extrusion function to

298 produce the S-phase arrest preceding extrusion either by promoting S-phase

299 entry (via cye-1 and cdk-2) or by preventing cell-cycle completion (via pig-1 and 300 grp-1).

$301 \quad$ Another difference consistent with the distinct ways by which the cell-cycle

302 genes and unequal-cell-division genes promote cell extrusion was observed in

303 the Tex phenotype caused by RNAi against these genes. Some pig-1(RNAi) and

304 grp-1(RNAi) animals with the Tex phenotype displayed two supernumerary

305 excretory cells (Figure 5I), presumably because both daughters of ABplpappap

306 adopted the excretory-cell in these animals. By contrast, cye-1(RNAi) and cdk-

307 2(RNAi) animals with the Tex phenotype displayed only one supernumerary

308 excretory cell (Figure 5I), presumably because ABplpappap did not enter and

309 then complete the cell cycle but rather differentiated directly into an excretory

310 cell.

311 In short, these findings indicate that the unifying feature of all genes

312 required for cell extrusion is that they function to produce the S-phase arrest

313 observed in cells to be extruded, supporting the conclusion that S-phase arrest is

314 a key requirement of cell extrusion. Either preventing cell-cycle entry or

315 bypassing the S-phase arrest to complete cell division prevented cell extrusion in

316 developing C. elegans embryos. 


\section{S-phase arrest drives cell extrusion from mammalian epithelial cultures}

319 Since S-phase arrest is the central feature of cell extrusion by C. elegans

320 embryo, we asked if S-phase arrest also induces mammalian cell extrusion. We

321 used a monolayer of Madin-Darby Canine Kidney (MDCK) cells as a model of

322 mammalian epithelia and hydroxyurea (HU) as a chemical agent for inducing S-

323 phase arrest. MDCK cells are a simple epithelial system for studies of

324 mammalian cell extrusion in culture (reviewed by Ohsawa et al., 2018). HU

325 causes S-phase arrest by inhibiting the enzyme ribonucleotide reductase and

326 depleting deoxyribonucleotides during DNA replication, resulting in stalled DNA

327 replication forks (Timson, 1975; Bianchi et al., 1983). We treated MDCK

328 monolayers with either $2 \mathrm{mM} \mathrm{HU}$ or vehicle (negative control) for up to $24 \mathrm{~h}$ and

329 obtained time-lapse micrographs of the monolayers from this period to assess

330 cell extrusion. Strikingly, cells extruded apically from the MDCK monolayer into

331 the culture medium were three to four times higher in number after HU treatment

332 when compared to the number of cells extruded apically after vehicle treatment

333 (Figure 6A, 6B; Movie 6,7). Next we used MDCK-Fucci cells to determine the cell

334 cycle phase distribution of HU- and vehicle-treated extruded cells (Streichan et

335 al., 2014). MDCK-Fucci cells produce a fluorescent signal that varies with the

336 phase of the cell cycle (G0/G1-Red, S/G2/M-Green; Sakaue-Sawano et al.,

337 2008). As expected, most of the HU-treated extruded cells displayed a green

338 fluorescent signal (Figure 6C), indicating that they were in a cell cycle phase

339 subsequent to the onset of DNA replication. We noted that stochastically

340 extruded cells (from vehicle treatment) mostly exhibited red fluorescence 
341 indicative of the G0 or G1 phase (Figure 6D), consistent with the phase of cells

342 that are naturally extruded from post-mitotic zones, such as the tips of intestinal

343 villi (Carroll et al., 2018; Eisenhoffer et al., 2012).

344 Since HU is known to increase the rate of apoptosis (Timson, 1975), and

345 agents that promote apoptosis increase the rate of cell extrusion (Andrade and

346 Rosenblatt, 2011), we examined the role of apoptosis in HU-induced cell

347 extrusion. Surprisingly, the fraction of extruded MDCK cells that were apoptotic

348 was not increased by HU treatment (Figure 6D), indicating that HU-induced cell

349 extrusion is not a consequence of an increase in the rate of apoptosis. In

350 addition, we reseeded the extruded MDCK cells in fresh media to measure their

351 viability following $\mathrm{HU}$ treatment. We found that the number of viable adherent

352 cells at 2 hours post reseeding was proportional to the number of extrusions for

353 both the HU- and vehicle-treated groups (Figure 6E). Additionally, the number of

354 HU-treated cells doubled at 24 hours post reseeding when compared to 2 hours

355 post reseeding (Figure 6E). Thus, cells extruded by HU treatment were not only

356 viable but also able to resume and complete the cell cycle.

357 Taken together, the above findings indicate that S-phase arrest drives the

358 extrusion of cells from mammalian epithelia and establish that cell extrusion

359 caused by S-phase arrest is an evolutionarily conserved phenomenon.

\section{DISCUSSION}

361 Here we report that cell cycle S-phase arrest is a cell-intrinsic trigger of

362 cell extrusion and can induce the extrusion of cells of organisms from two

363 divergent branches of the phylogenetic tree - nematodes and mammals. Using 
364 RNAi screens and transgenic cell-cycle reporters, we determined in developing

365 C. elegans embryos that perturbations that prevented S-phase arrest blocked cell

366 extrusion. As summarized in Figure 7A, cells destined for extrusion from ced-3(If)

367 embryos are always the smaller daughters of unequal cell divisions. These

368 smaller daughter cells enter $S$ phase of the cell cycle and undergo S-phase

369 arrest, likely because of a deficiency in the energetic and metabolic resources

370 required for DNA synthesis (e.g., nucleotides, replication proteins, etc.). Thus,

371 either bypassing S-phase arrest (by perturbing the process of unequal cell

372 division) and hence completing cell division or preventing S-phase arrest (by

373 blocking cell-cycle entry) prevents cell extrusion in C. elegans embryos.

374 To test the generality of our findings, we used mammalian epithelia

375 treated with HU and showed that S-phase arrest is sufficient to promote cell

376 extrusion. Thus, cell extrusion triggered by S-phase arrest is an evolutionarily

377 conserved mechanism of cell elimination. These observations also demonstrate

378 that cells can be extruded from mitotically active mammalian epithelial tissues.

379 Previous studies of mammalian cell extrusion focused on extrusion from post-

380 mitotic tissues (Rosenblatt et al., 2001; Eisenhoffer et al., 2012; Gudipaty et al.,

381 2017; Saw et al., 2017; Kocgozlu et al., 2016) or oncogene-driven extrusion from

382 growth-suppressing epithelial environments (Anton et al., 2018; Hogan et al.,

383 2009; Kajita et al., 2010; Leung and Brugge, 2012; Slattum et al., 2014; Wu et 384 al., 2014).

385 Our mechanistic model for the evolutionarily conserved process by which

386 S-phase arrest promotes cell extrusion is presented in Figure 7B. In this model, a 
387 mitotically active cell destined for extrusion (i) enters the cell cycle, (ii) arrests in

388 S phase, (iii) loses cell adhesion (see below), and (iv) is extruded as a result of

389 reduced adhesion and forces generated by external morphological or

390 physiological processes.

391 Why are S-phase arrested cells susceptible to extrusion?

392 We observed previously that cells extruded by $C$. elegans embryos do not

393 express the classical E-cadherin HMR-1 and other cell-adhesion molecules

394 (Denning et al., 2012). The absence of such adhesion molecules likely allows

395 cells to be squeezed out of the embryo by morphological forces generated by

396 migrating hypodermal cells and neighboring neuroblasts during ventral enclosure

397 (Chisholm and Hardin, 2005; Wernike et al., 2016). Consistent with this view, the

398 loss of E-cadherin-mediated adhesion caused by cleavage of the extracellular

399 part of a cell's E-cadherin molecules is sufficient to drive cell extrusion from an

400 MDCK monolayer (Grieve and Rabouille, 2014). We speculate that a signaling

401 pathway initiated by S-phase arrest downregulates the expression of cell

402 adhesion molecules in cells destined for extrusion. Indeed, in HeLa cell cultures,

403 cell adhesion increases during S phase via the activity of the cell-cycle regulator

404 CDK1 and decreases later in the cell cycle upon inhibition of CDK1 by Wee1

405 (Jones et al., 2018). Interestingly, activation of the replication stress response,

406 which is required for cell extrusion in C. elegans (Figure 1C, 4L), blocks CDK1

407 activity (Jin et al., 2003; Mailand et al., 2002; Xiao et al., 2003). Furthermore, HU-

408 mediated S-phase arrest also inactivates CDK1 in MDCK cells (Anton et al.,

409 2018). We therefore propose that a reduction in CDK1 activity following S-phase 
410 arrest decreases cell adhesion, thereby facilitating the extrusion of cells

411 subjected to external forces from cellular neighbors.

412 Extrusion of S-phase arrested cells is likely tumor-suppressive

413 Replication forks under prolonged S-phase arrest can collapse and

414 produce DNA damage, genomic rearrangements and ploidy defects, all of which

415 are associated with oncogenesis (reviewed by Gaillard et al., 2015). The human

416 genes that promote replication stress and S-phase arrest are frequently

417 amplified, overexpressed or activated by mutations in tumors (Otto and Sicinski,

418 2017). Cells in such tumors experience persistent replication stress that can lead

419 to S-phase arrest (Gaillard et al., 2015). Hence, tumor cells and cells with

420 oncogenic potential might well be eliminated via cell extrusion, in which case the

421 extrusion of cells arrested in S phase would be tumor-suppressive. We propose

422 that cell extrusion driven by S-phase arrest is a checkpoint mechanism that

423 functions to eliminate cells at all stages of the oncogenic transformation process,

424 ranging from precancerous cells in S-phase arrest to tumor cells in a malignant

425 tumor.

426 Subversion of cell extrusion driven by S-phase arrest might contribute to

\section{7 metastasis}

428 Inactivation of either $\mathrm{S} \mathrm{P}_{2}$ or the tumor suppressor APC or expression of

429 oncogenic K-Ras changes the direction of cell extrusion from apical, which favors

430 cell elimination by extrusion into the lumen, to basal, which favors dissemination

431 of extruded cells to surrounding tissue (Gu et al., 2015; Marshall et al., 2011;

432 Slattum et al., 2014). Mutations in these genes are hallmarks of metastatic 
433 tumors. While cell extrusion caused by S-phase arrest likely can suppress tumor

434 development, the same mechanism of cell extrusion might paradoxically promote

435 cancer metastasis if the extrusion direction changes from apical to basal. We

436 observed that cells subjected to HU-mediated extrusion failed to die (Figure 6D)

437 and instead were capable of reentering the cell cycle and proliferating (Figure

438 6E). Thus, basal extrusion of cells arrested in S-phase might facilitate metastasis

439 by disseminating live tumor cells arrested in S phase to other tissues and organs.

440 We propose that mutations in genes, such as $\mathrm{S}_{1} \mathrm{P}_{2}, \mathrm{APC}$ and $\mathrm{K}-\mathrm{Ras}$, promote

441 metastasis by facilitating the basal extrusion and spread of tumor cells arrested

442 in S phase.

443 In summary, we have discovered a novel conserved mechanism that links

444 a cell-cycle vulnerability to the process of cell extrusion. We suggest that cell

445 extrusion mediated by S-phase arrest is a mechanism of cell elimination common

446 to all metazoa. These findings have implications for the field of cancer biology, as

447 cell extrusion caused by S-phase arrest likely regulates both the survival and 448 spread of tumor cells. 


\section{ACKNOWLEDGMENTS}

451 We thank S. van den Heuvel for providing strains; the CGC, which is funded by

452 NIH Office of Research Infrastructure Programs (P40 OD010440), for providing

453 some strains; N. An and T. Ljungars for strain management; S. Luo, S.R. Sando,

454 A. Doi, and A. Corrionero and other members of the Horvitz laboratory for helpful

455 discussions, and D. Ghosh, C.L. Pender, J.N. Kong, M.G. Vander Heiden, P.W.

456 Reddien, R.O. Hynes for suggestions regarding the manuscript. V.K.D. was a

457 Howard Hughes Medical Institute International Student Research fellow. C.P.P.

458 is the recipient of a Human Frontiers Science Program postdoctoral fellowship

459 (LT000654/2019-L). J.R. and C.P.P. were funded by King's College London

460 startup funds. H.R.H. is the David H. Koch Professor of Biology at MIT and an

461 Investigator at the Howard Hughes Medical Institute.

\section{AUTHOR CONTRIBUTIONS}

463 H.R.H. supervised the project. V.K.D. and H.R.H. conceptualized the project.

464 V.K.D. and H.R.H. designed the experiments that used C. elegans. V.K.D. and 465 R.D. performed the experiments that used C. elegans. V.K.D., R.D. and D.P.D. 466 generated reagents. C.P. and J.R. designed the experiments that used 467 mammalian cells. C.P. performed the experiments that used mammalian cells. 468 V.K.D., D.P.D. and H.R.H. wrote the original manuscript draft. All authors 469 contributed to data analysis, interpretation, and reviewing and editing of the 470 manuscript.

\section{Declaration of Interests}

472 The authors declare no competing interests. 


\section{Figure 1}

A

\section{Wild type}

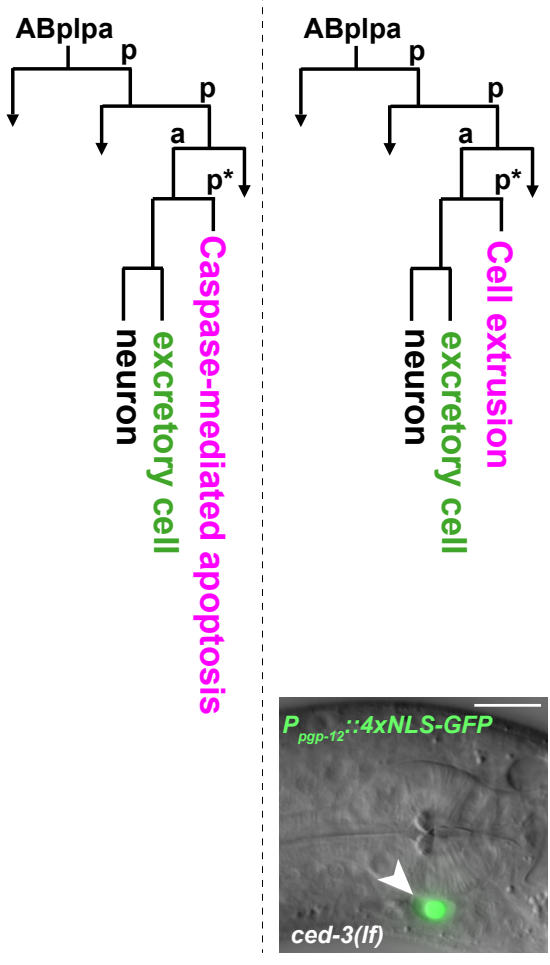

ced-3(If) + extrusion defect

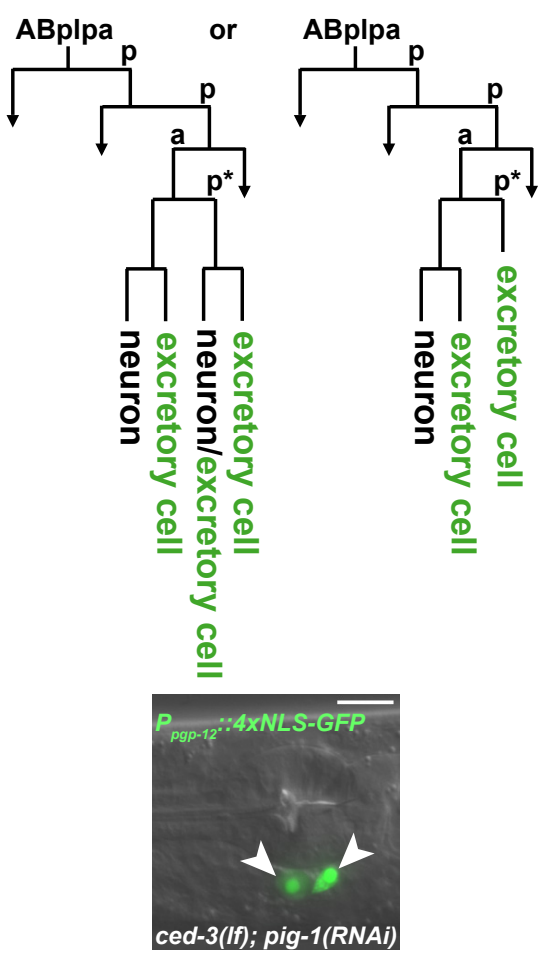

B

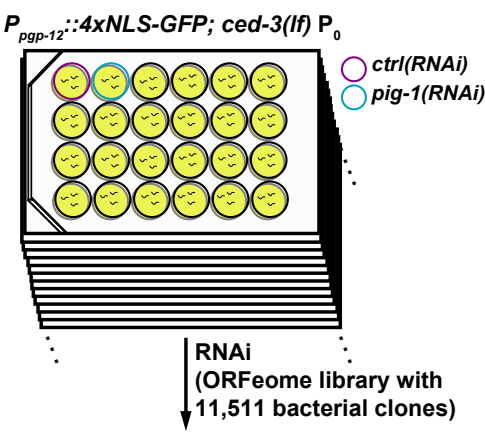

$P_{\text {pgp-12: }}:: 4 \times N L S-G F P ;$ ced-3(If) $\mathrm{F}_{1}$

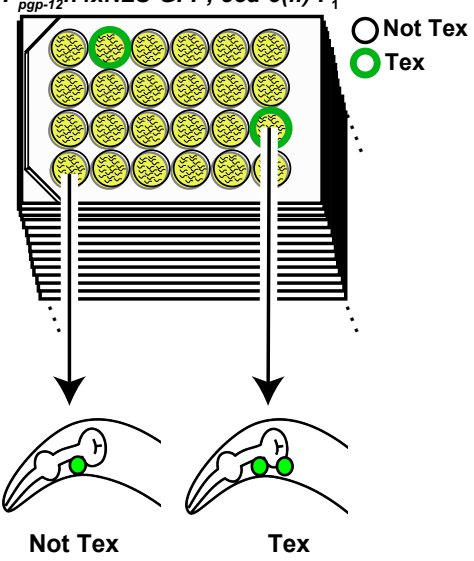

11,481 RNAi clones 30 RNAi clones

C

\section{Cell cycle genes with a candidate role in cell extrusion based on RNAi-induced Tex phenotype}

\begin{tabular}{|c|c|c|c|c|}
\hline $\begin{array}{l}\text { RNAi target } \\
\text { gene }\end{array}$ & $\% \operatorname{Tex}(n)$ & $\begin{array}{l}\text { Mammalian } \\
\text { homolog }\end{array}$ & G1/S Role & Role/Function in cell cycle \\
\hline Control & $1(107)$ & - & - & - \\
\hline$c d c-25.2^{\ddagger}$ & 21(159) & CDC25 & Yes & $\begin{array}{l}\text { Protein phosphatase that removes inhibitory phosphorylations } \\
\text { from cyclin dependent kinases (CDKs) } 1 \text { and } 2\end{array}$ \\
\hline cya-1 $1^{\ddagger}$ & $12(363)$ & Cyclin A & Yes & $\begin{array}{l}\text { Protein that binds to } C D K 2 \text { to regulate } S \text {-phase progression } \\
\text { and to } C D K 1 \text { to regulate progression through } G 2 \text { and } M \text { phases }\end{array}$ \\
\hline cye- $1^{\ddagger}$ & $87(165)$ & Cyclin E & Yes & $\begin{array}{l}\text { Protein that binds to CDK2 to regulate transition from } \\
\text { G1 to } S \text { phase of the cell cycle }\end{array}$ \\
\hline$c d k-1^{\ddagger}$ & $15(61)$ & CDK1 & Yes & $\begin{array}{l}\text { CDK that can bind to multiple cyclin proteins to phosphorylate } \\
\text { targets for the positive regulation of cell cycle progression }\end{array}$ \\
\hline$c d k-2$ & 65 (181) & CDK2 & Yes & $\begin{array}{l}\text { CDK that binds to Cyclins } E \text { and } A \text { to promote } S \text {-phase entry } \\
\text { and progression, respectively }\end{array}$ \\
\hline $\begin{array}{l}\text { psf-1 } \\
\text { psf-2 } \\
\text { psf-3 }\end{array}$ & $\begin{array}{l}36(116) \\
39(156) \\
50(105)\end{array}$ & GINS Complex & Yes & $\begin{array}{l}\text { Proteins that function as components of a complex that is } \\
\text { involved in DNA replication origin firing and replication progression }\end{array}$ \\
\hline $\begin{array}{l}\operatorname{csn}-1^{\ddagger} \\
\operatorname{csn}-4^{\ddagger} \\
\operatorname{csn}-5^{\ddagger}\end{array}$ & $\begin{array}{l}43(132) \\
47(141) \\
39(145)\end{array}$ & $\begin{array}{c}\text { COP9 } \\
\text { Signalosome }\end{array}$ & Maybe & $\begin{array}{l}\text { Proteins that function as components of a complex that is required } \\
\text { for the function of SCF E3 ligases that regulate the cell cycle }\end{array}$ \\
\hline $\begin{array}{l}\text { atl-1 } \\
\text { chk-1 }\end{array}$ & $\begin{array}{l}9(444) \\
9(220)\end{array}$ & $\begin{array}{l}\text { ATR } \\
\text { Chk1 }\end{array}$ & Yes & Proteins that function in the replication stress checkpoint response \\
\hline
\end{tabular}


473 Figure 1 A Genome-wide RNAi screen for genes required for cell extrusion

\section{4 identifies multiple cell-cycle genes}

475 (A) Lineage diagrams show the fate of the cell ABplpappap (marked with an *) in 476 embryos that are wild-type, embryos with a ced-3(If) mutation and embryos with 477 a ced-3(If) mutation and a defect in cell extrusion. A micrograph of the 478 pharyngeal region showing excretory cell(s), which express nuclear GFP and are 479 marked with white arrowhead(s), is shown for a representative ced-3(If) animal 480 and a ced-3(If) + extrusion defect (ced-3(If); pig-1(RNAi)) animal below the 481 corresponding cell-lineage diagrams. Scale bar, $10 \mu \mathrm{m}$.

482 (B) Schematic representation of the genome-wide RNAi screen for the Tex 483 phenotype.

484 (C) RNAi clone targets with a function in the cell cycle identified from the 485 genome-wide or candidate-based RNAi screens for the Tex phenotype and the 486 corresponding penetrance of the Tex phenotype. The mammalian homologs of 487 these genes and their functions in mammals are shown. G1/S Role indicates 488 whether an identified RNAi target has a role in G1, G1-to-S phase transition or S489 phase progression in mammals. $¥$, genes identified from the genome-wide RNAi 490 screen; other genes were identified from a candidate RNAi screen of cell cycle 491 genes for the Tex phenotype (Supplemental Table 1). 
bioRxiv preprint doi: https://doi.org/10.1101/839845; this version posted November 13, 2019. The copyright holder for this preprint (which was not certified by peer review) is the author/funder, who has granted bioRxiv a license to display the preprint in perpetuity. It is made available under aCC-BY-NC-ND 4.0 International license.

Figure 2

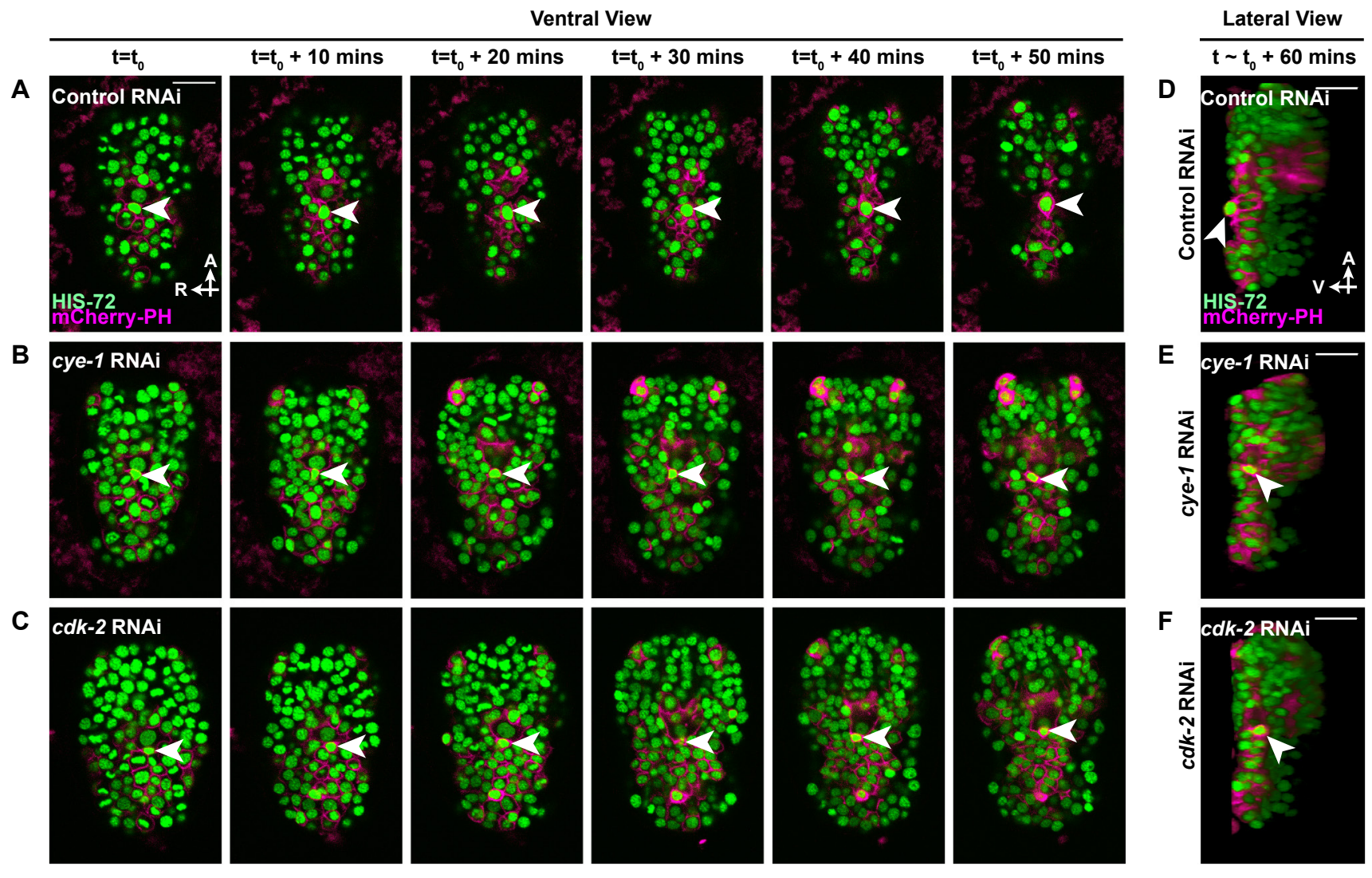


493 Figure 2 Cell extrusion of ABplpappap requires the function of the cell-

\section{4 cycle genes cye-1 and cdk-2}

495 (A-C) Micrographs of the ventral surface obtained at 10-min intervals over a 496 period of 50 min using time-lapse confocal microscopy show the location of 497 ABplpappap (arrowhead) on the ventral surface with respect to other embryonic 498 cells in (A) control, (B) cye-1(RNAi), and (C) cdk-2(RNAi) embryos. The embryos 499 shown carried the transgenes st/s10026 and nls632. A, anterior; R, right. Scale 500 bar, $10 \mu \mathrm{m}$.

501 (D-F) Virtual lateral sections through the ABplpappap cell in ced-3(If) embryos 502 show the relative location of ABplpappap (arrowhead) in (D) control, (E) cye503 1(RNAi), and (F) cdk-2(RNAi) embryos. Embryos shown in (D), (E) and (F) are 504 the same as those in (A), (B) and (C), respectively. A, anterior; $V$, ventral. Scale 505 bar, $10 \mu \mathrm{m}$. 
bioRxiv preprint doi: https://doi.org/10.1101/839845; this version posted November 13, 2019. The copyright holder for this preprint (which was not certified by peer review) is the author/funder, who has granted bioRxiv a license to display the preprint in perpetuity. It is made available Figure 3

tDHB-GFP Localization

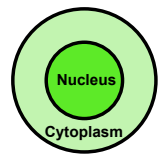

Quiescent/post-mitotic cell

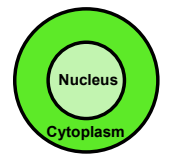

Proliferating cell

Before ventral enclosure
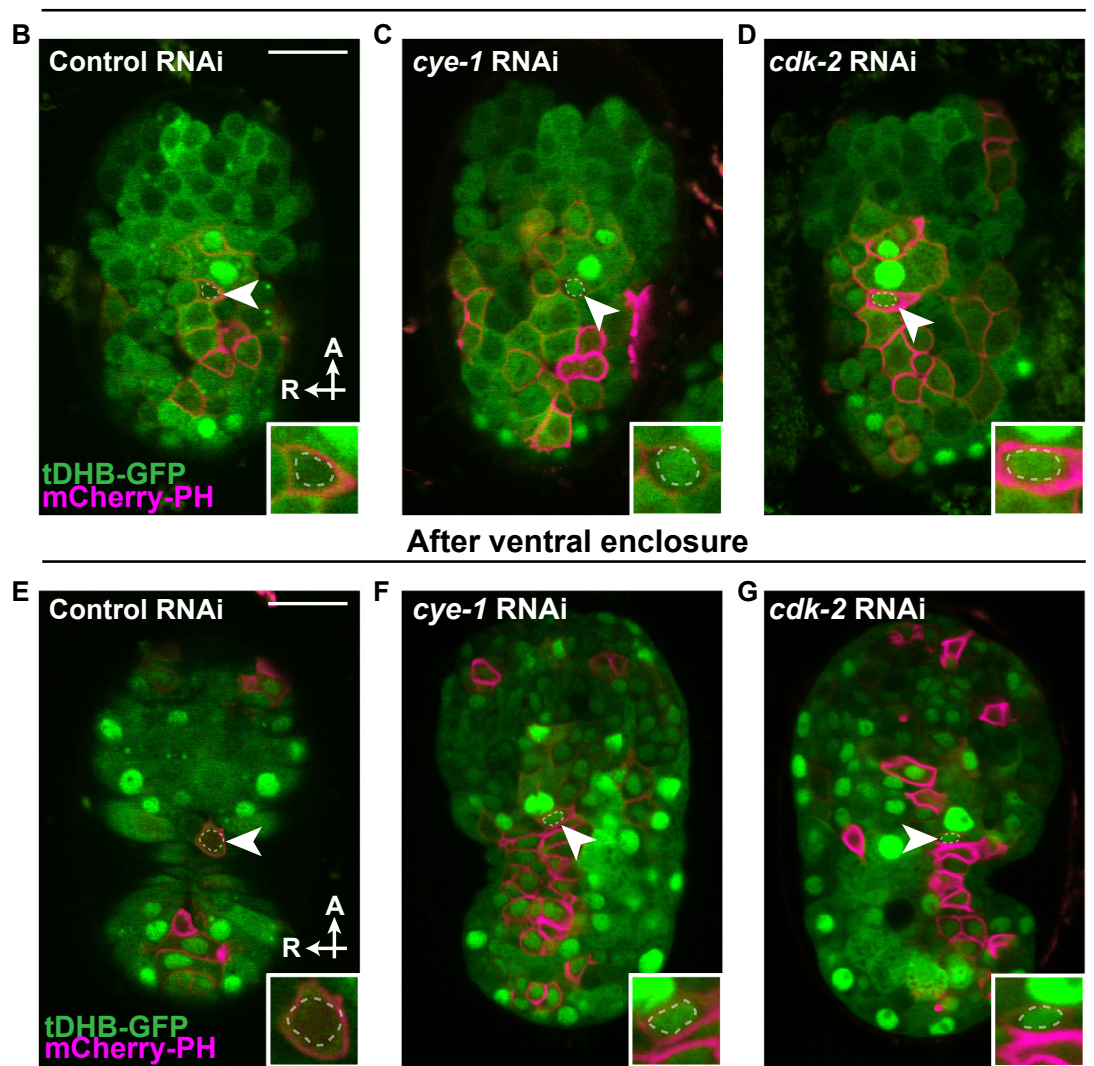

H

tDHB-GFP distribution between nucleus and cytoplasm of $A B p l p a p p a p$
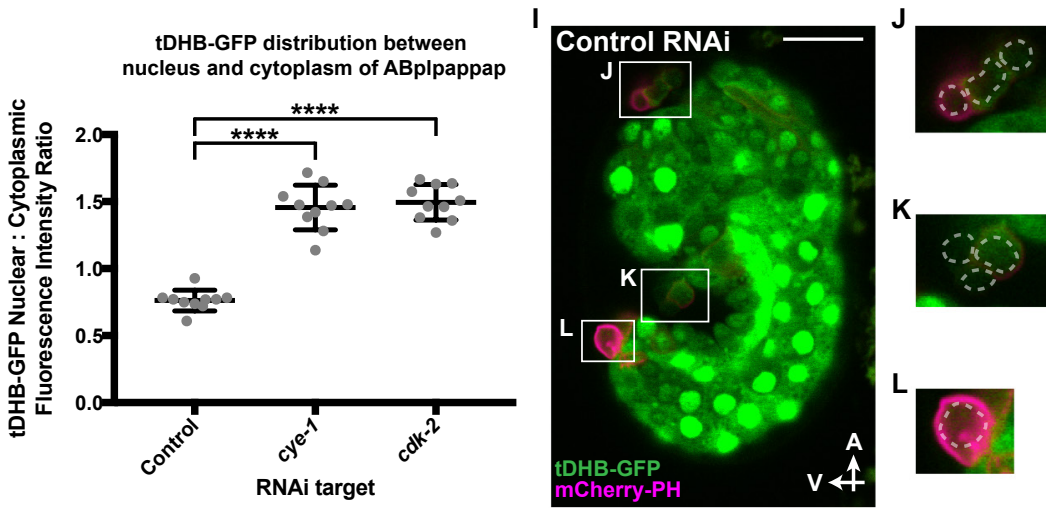
507 Figure 3 Cells that are extruded enter the cell cycle and are extruded in a 508 cye-1- and cdk-2 -dependent manner

509 (A) Schematic showing the relative nuclear/cytoplasmic localization of a 510 truncated DHB (tDHB) - GFP fusion protein in a quiescent/post-mitotic cells and 511 in cells between S phase and mitosis in the cell cycle (van Rijnberk et al., 2017).

512 (B-G) Micrographs of the ventral surface, including ABplpappap (arrowhead), of 513 ced-3(If) embryos expressing tDHB-GFP obtained (B-D) prior to and (E-G) post

514 ventral enclosure using confocal microscopy in $(B, E)$ control embryos, $(C, F)$ cye5151 (RNAi) embryos, and (D,G) cdk-2(RNAi) embryos. Inset, a magnified view of 516 the ABplpappap cell. The ABplpappap nucleus, as determined by Nomarski 517 optics, is marked by a dotted line in each image and inset. The embryos shown 518 carried transgenes heSi192 and nls861. A, anterior; R, right. Scale bar, $10 \mu \mathrm{m}$.

$519(\mathrm{H})$ Quantification of the ratio of tDHB-GFP fluorescence intensity in the nucleus 520 to that in the cytoplasm in control, cye-1(RNAi), or cdk-2(RNAi) embryos 521 expressing tDHB-GFP. ${ }^{* * * *}, p<0.0001$ per ordinary one-way ANOVA of the log of 522 ratios. $\mathrm{n}=10$ embryos per RNAi treatment.

523 (I-L) Micrograph of (I) a ced-3(If) embryo expressing tDHB-GFP obtained at the 524 comma stage using confocal microscopy. Magnified views are provided for the 525 cells extruded at $(\mathrm{J})$ the anterior sensory depression, $(\mathrm{K})$ the ventral pocket, and 526 (L) the posterior tip of the embryo, with the corresponding regions outlined in (I). 527 The cell nucleus, as determined by Nomarski optics, is marked by a dotted line 528 for each extruded cell in the magnified images $(\mathrm{J}),(\mathrm{K})$ and $(\mathrm{L})$. The embryo 
bioRxiv preprint doi: https://doi.org/10.1101/839845; this version posted November 13,2019 . The copyright holder for this preprint (which was not certified by peer review) is the author/funder, who has granted bioRxiv a license to display the preprint in perpetuity. It is made available under aCC-BY-NC-ND 4.0 International license.

529 shown carried the transgenes heSi192 and nls861. A, anterior; V, ventral. Scale

530 bar, $10 \mu \mathrm{m}$.

531 
A

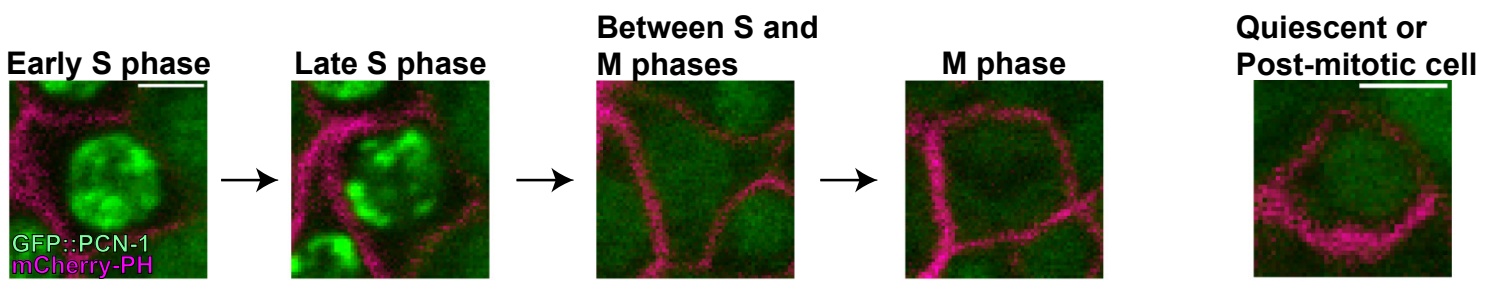

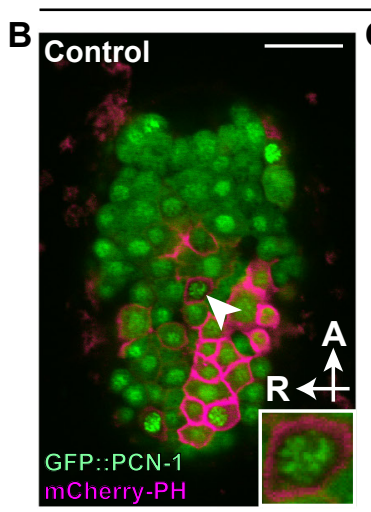

Before ventral enclosure
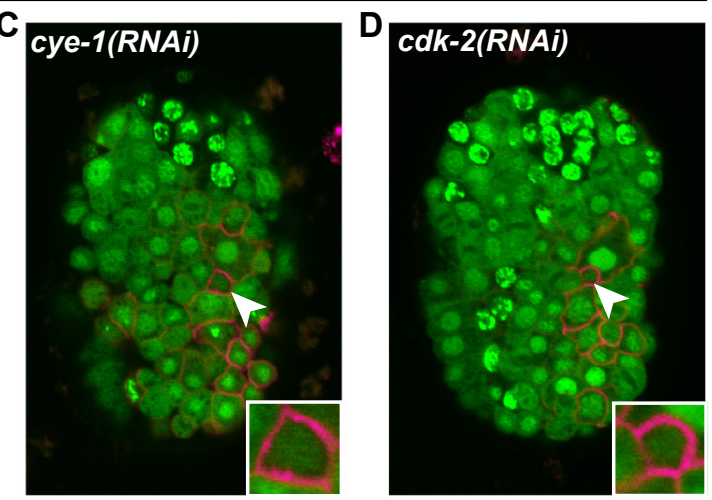

After ventral enclosure
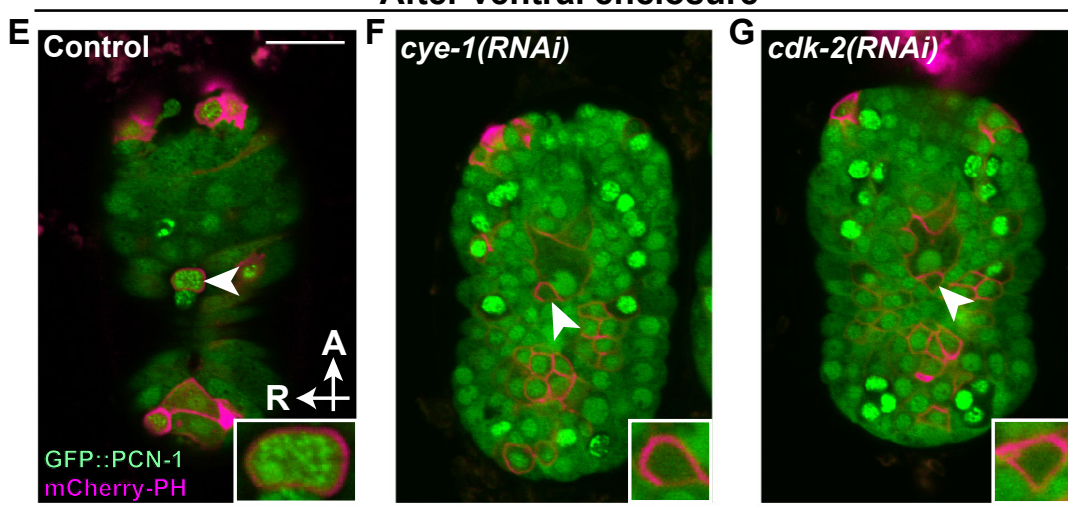

H

$\mathrm{t}=\mathrm{t}_{0}$

$\mathrm{t}=\mathrm{t}_{0}+5 \mathrm{mins}$

$t=t_{0}+10$ mins

$\mathrm{t}=\mathrm{t}_{0}+15 \mathrm{mins}$

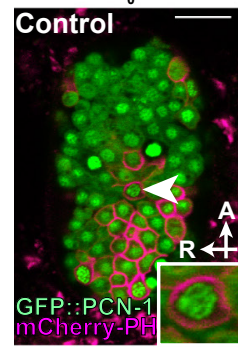

$t=t_{0}+20$ mins

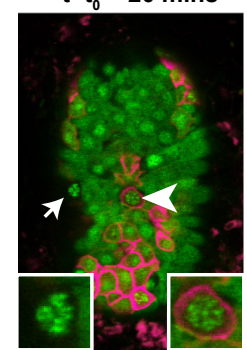

$\mathbf{t}=\mathrm{t}_{0}+25 \mathrm{mins}$
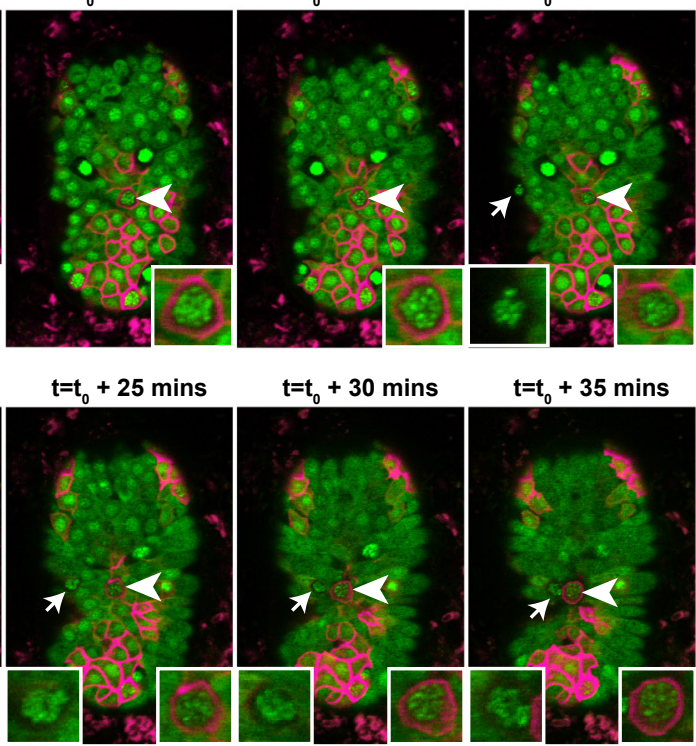

$t=t_{0}+30$ mins

$t=t_{0}+35$ mins

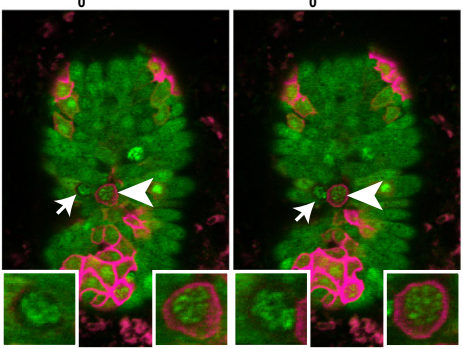

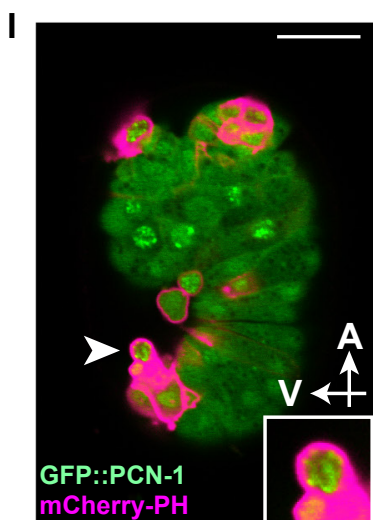

J Control

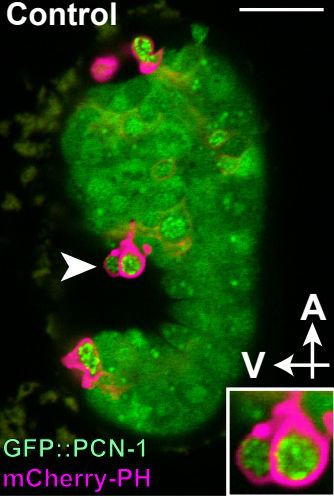

K

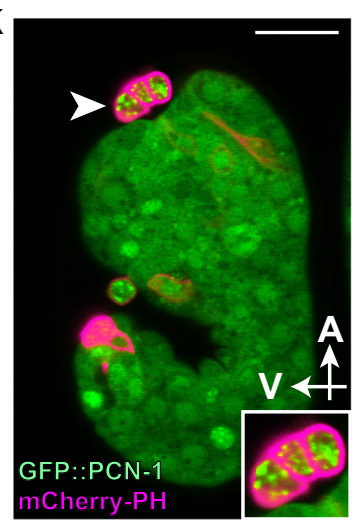

L

\begin{tabular}{cccc}
\hline RNAi Target & $\begin{array}{c}\text { Mammalian } \\
\text { homolog }\end{array}$ & \% Tex & $\mathrm{n}$ \\
\hline Control & - & 4 & 235 \\
hpr-9 & RAD9 & 12 & 422 \\
tim-1 & TIMELESS & 21 & 385 \\
tipn-1 & TIPIN & 10 & 367 \\
mus-101 & TOPBP1 & 18 & 162 \\
clsp-1 & CLSPN & 18 & 141 \\
\hline
\end{tabular}


532 Figure 4 Cells undergoing extrusion arrest in S phase and trigger the DNA

\section{3 replication stress checkpoint}

534 (A) Representative micrographs showing localization patterns of GFP::PCN-1 in

535 the same cell at different phases of the cell cycle or in a different cell in a post-

536 mitotic state. The post-mitotic cell shown is ABplpappaaa (future RMEV neuron).

537 These cells were imaged from a ced-3(If) embryo, which carried the transgenes

$538 n$ nls861 and is/s17. Scale bar, $2 \mu \mathrm{m}$.

539 (B-G) Micrographs of the ventral surface, including ABplpappap (arrowhead), of

540 ced-3(If) embryos expressing GFP::PCN-1 obtained (B-D) prior to and (E-G) post

541 ventral enclosure using confocal microscopy in $(B, E)$ control embryos, $(C, F)$ cye-

542 1(RNAi) embryos, and $(D, G) c d k-2(R N A i)$ embryos. Inset, a magnified view of

543 ABplpappap. The embryos shown carried the transgenes $n / s 861$ and is/s17. A,

544 anterior; $\mathrm{R}$, right. Scale bar, $10 \mu \mathrm{m}$.

$545(\mathrm{H})$ Micrographs obtained at 5-min intervals using time-lapse confocal

546 microscopy show the GFP::PCN-1 localization pattern in ABplpappap

547 (arrowhead) and another unidentified extruded cell (arrow) as they were

548 progressively extruded over $35 \mathrm{~min}$ in a ced-3(If) embryo with control RNAi. Left

549 insets, magnified views of unidentified extruded cell; right insets, magnified views

550 of ABplpappap. The embryo shown carried the transgenes is/s17 and $n / s 861$.

551 The decrease in fluorescence intensity can be attributed to bleaching from

552 repeated imaging over time. A, anterior; $\mathrm{R}$, right. Scale bar, $10 \mu \mathrm{m}$.

553 (I-K) Micrographs of extruded cells in ced-3(If) embryos expressing GFP::PCN-1

554 obtained at the comma stage using confocal microscopy show GFP.:PCN-1 
555 localization in cells at (I) the posterior tip of the embryo (no RNAi), (J) the ventral

556 pocket (control RNAi), and (K) the anterior sensory depression (no RNAi). Inset,

557 a magnified view of extruded cells marked by an arrowhead. The embryos shown

558 carried the transgenes is/s17 and $n / s 861$. A, anterior; V, ventral. Scale bar, 10

$559 \mu \mathrm{m}$.

560 (L) Penetrances of the Tex phenotype produced by RNAi-mediated targeting of

561 replication-stress checkpoint genes hpr-9, tim-1, tipn-1, mus-101 and clsp-1 in

562 ced-3(If) animals. The strain used for scoring the RNAi-induced Tex phenotype

563 carried the transgene $n / s 433$, which expresses nuclear GFP in excretory cell(s).

564 

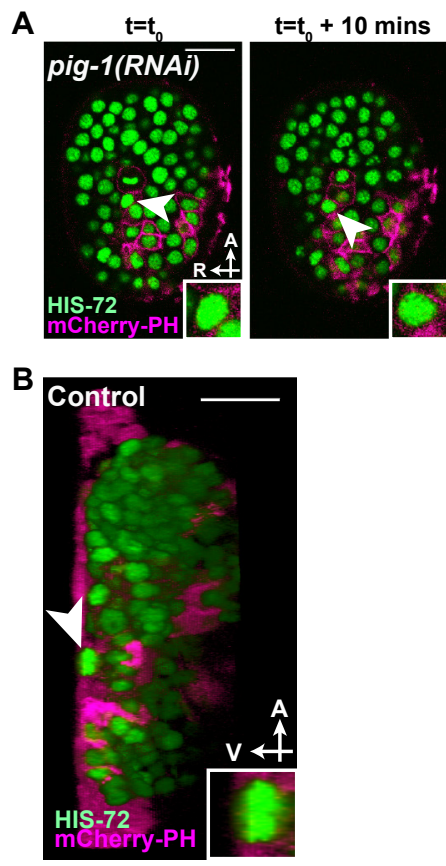

E

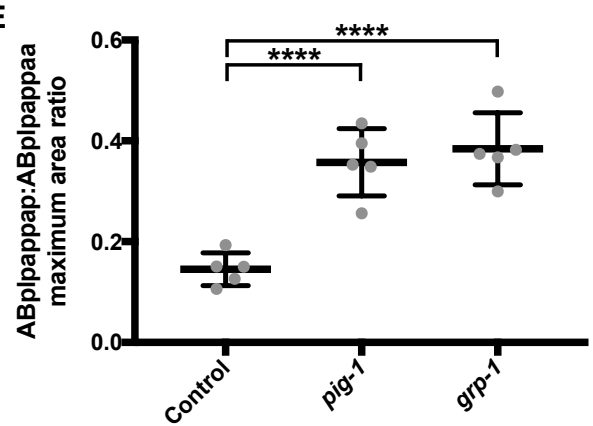

G

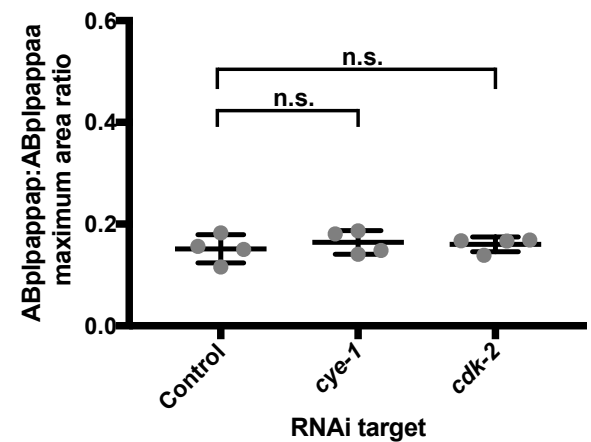

$\mathbf{F}$

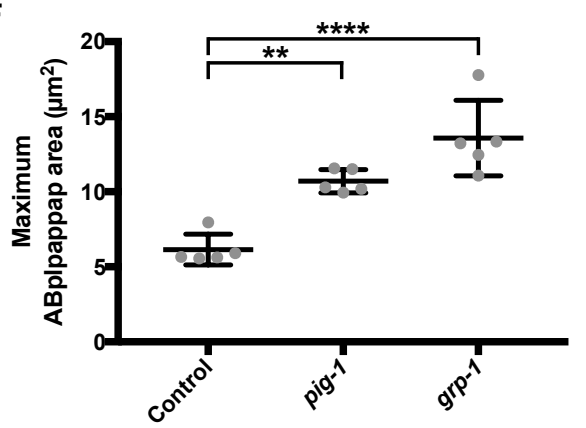

$\mathbf{H}$

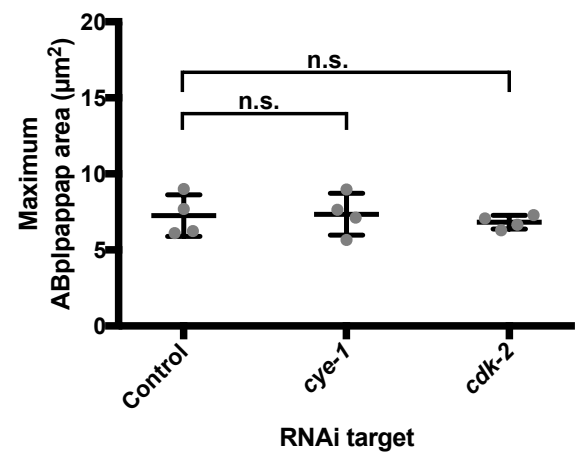

\begin{tabular}{cccccc}
\hline RNAi Target & $\%$ Tex & \multicolumn{3}{c}{ No. of animals } & $\begin{array}{c}\text { Total no. of } \\
\text { animals }\end{array}$ \\
\hline Control & 1 & 171 & 1 & 0 & 172 \\
pig-1 & 74 & 50 & 106 & 39 & 195 \\
grp-1 & 83 & 32 & 103 & 54 & 189 \\
cye-1 & 75 & 58 & 170 & 0 & 228 \\
cdk-2 & 77 & 54 & 177 & 0 & 231 \\
\hline
\end{tabular}


565 Figure 5 Unequal cell division genes pig-1 and grp-1 promote extrusion by

\section{6 preventing cell-cycle progression beyond S phase}

567 (A) Micrographs of a pig-1(RNAi) embryo obtained at 10-min intervals over a 568 period of 50 min using time-lapse confocal microscopy show that an enlarged 569 ABplpappap divides before ventral enclosure in pig-1(RNAi) embryos. The 570 embryo shown carried the transgenes st/s10026 and $n / s 861$. Inset, a magnified 571 view of ABplpappap or its descendants. A, anterior; R, right. Scale bar, $10 \mu \mathrm{m}$.

572 (B-D) Virtual lateral sections of ced-3(If) embryos through ABplpappap (single 573 arrowhead) or its daughters (two arrowheads) in a (B) control embryo, (C) pig574 1(RNAi) embryo, and (D) grp-1(RNAi) embryo. Inset, a magnified view of 575 ABplpappap or its descendants. The embryos shown carry the transgenes $576 s t / s 10026$ and $n / s 861$. A, anterior; V, ventral. Scale bar, $10 \mu \mathrm{m}$.

577 (E) Ratio of maximum area (see Materials and methods) of ABplpappap to that of 578 its sister in ced-3(If) embryos with RNAi against control, pig-1 or gpr-1. Error 579 bars, standard deviation. ${ }^{* * * *}, p<0.0001$ per ordinary one-way ANOVA of log of 580 ratios. $\mathrm{n}=5$ embryos for each RNAi treatment.

581 (F) Quantification of the maximum area (see Materials and methods) of 582 ABplpappap in control embryos, pig-1(RNAi) embryos and grp-1(RNAi) embryos.

583 Error bars, standard deviation. ${ }^{* *}, p<0.01 ;{ }^{* * *}, p<0.0001$ per ordinary one-way 584 ANOVA. $\mathrm{n}=5$ embryos for each RNAi treatment.

585 (G) Ratio of maximum area (see Materials and methods) of ABplpappap to that 586 of its sister in ced-3(If) embryos with RNAi against control, cye-1 or cdk-2. Error 
587 bars, standard deviation. n.s., not significant per ordinary one-way ANOVA of log

588 of ratios. $n=4$ embryos for each RNAi treatment.

589 (H) Quantification of the maximum area (see Materials and methods) of

590 ABplpappap in control embryos, cye-1(RNAi) embryos and cdk-2(RNAi)

591 embryos. Error bars, standard deviation. n.s., not significant per ordinary one-

592 way ANOVA. $n=4$ embryos for each RNAi treatment.

593 (I) Penetrances of the Tex phenotype and number of animals with one, two or

594 three excretory cells produced by RNAi against genes identified from genetic

595 screens for defective extrusion. The ced-3(If) strain used for this experiment

596 carries the transgene $n / s 433$.

597 
Figure 6

A

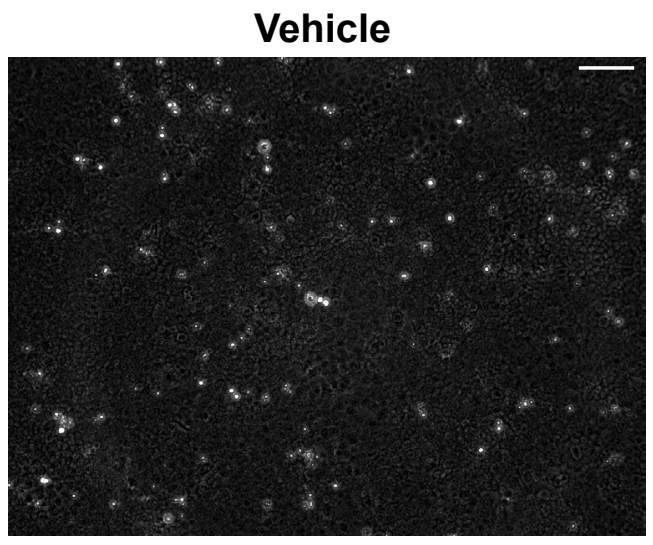

B

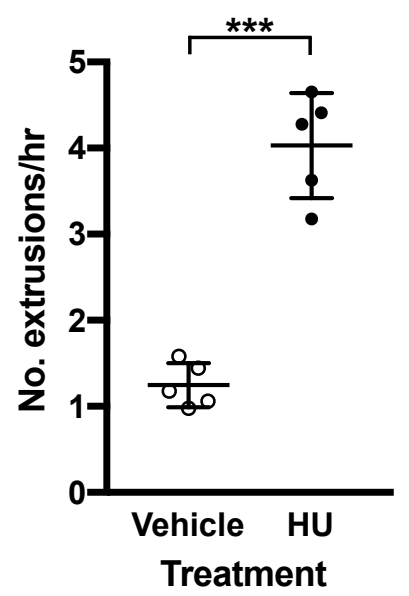

D

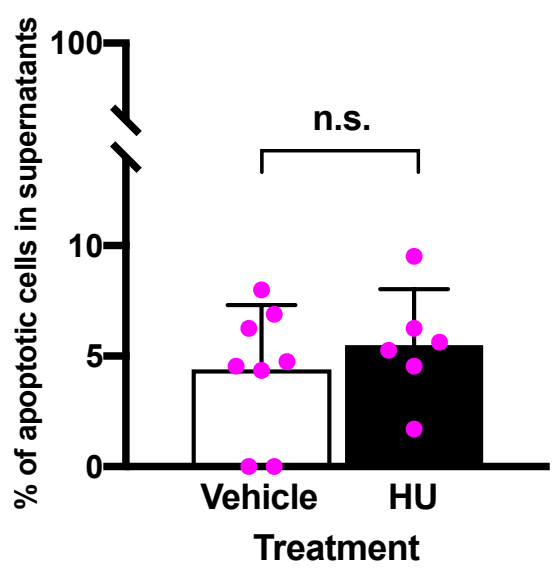

C
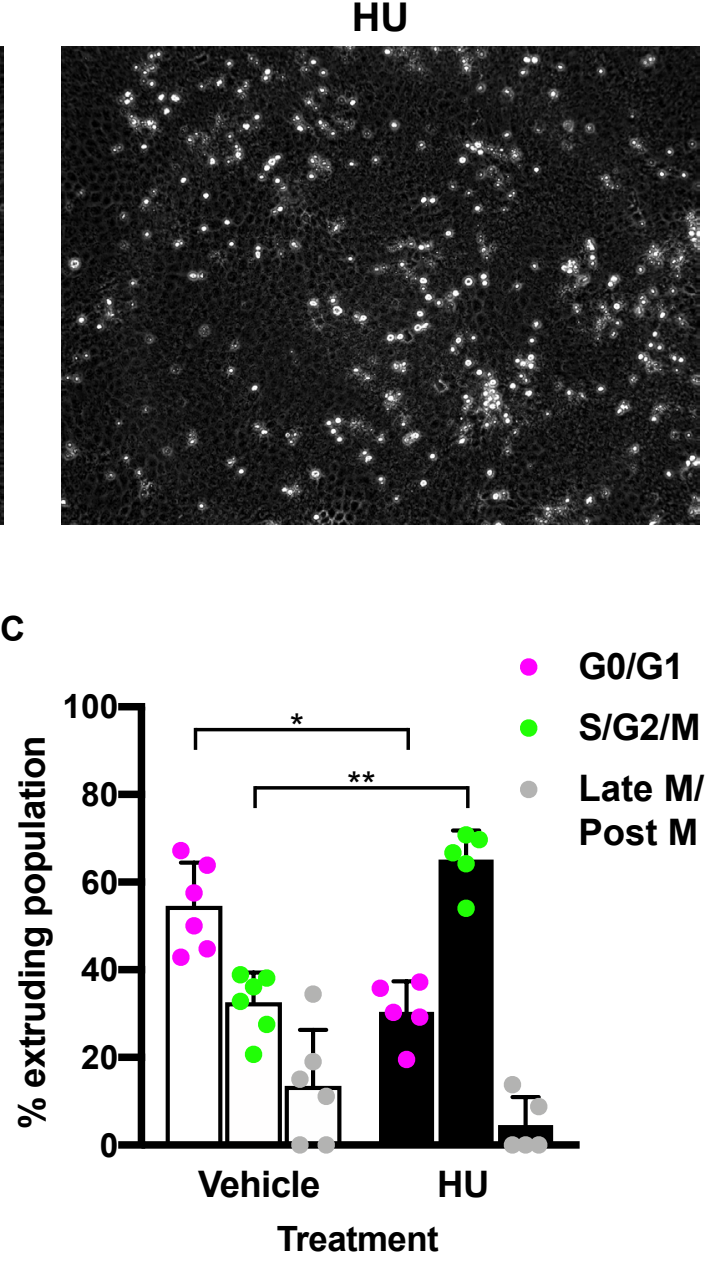

E

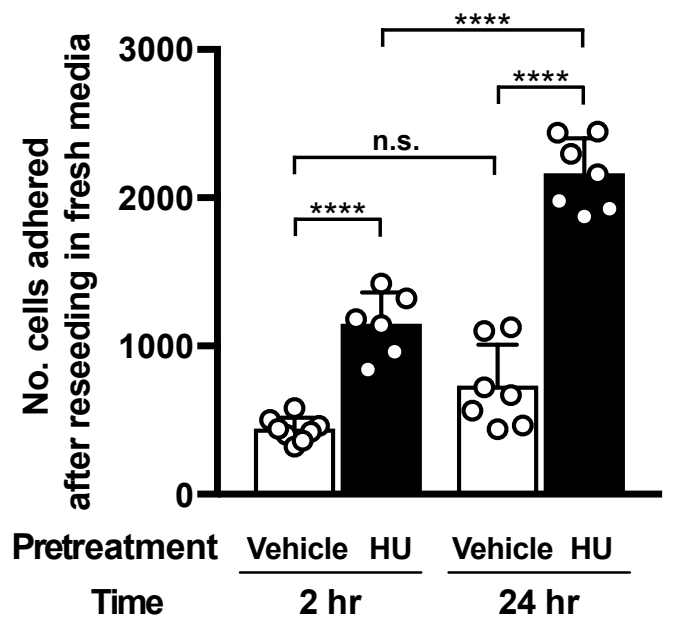


598 Figure 6 S-phase arrest is sufficient for cell extrusion from a simple

\section{9 mammalian epithelial layer}

600 (A) Representative images from time-lapse videos of mammalian MDCK cell 601 monolayers exposed to either vehicle or $2 \mathrm{mM}$ hydroxyurea (HU) at $22 \mathrm{~h}$ of 602 exposure. Extruded cells can be identified as bright, white, rounded spots rising 603 from the epithelial plane. Many more extruded cells are observed after HU 604 treatment as compared to vehicle treatment. Scale bar, $100 \mu \mathrm{m}$.

605 (B) Graph showing average number of cell extrusions per $\mathrm{h}$ in vehicle-treated 606 and $2 \mathrm{mM} \mathrm{HU}$-treated MDCK monolayers. Each data point represents a separate 607 experiment conducted for up to $24 \mathrm{~h}$ normalized by duration of experiment for 608 comparison. Error bars, standard deviation. ${ }^{* * *}, p<0.001$ per Welch's two-tailed 609 t-test. n=5 measurements experimental replicates for each condition.

610 (C) Graph showing cell cycle phase distribution of extruded MDCK-FUCCl cells

611 after HU treatment or vehicle treatment. Each data point represents a separate 612 experiment. Error bars, standard deviation. *, $p<0.05$; ${ }^{* *}, p<0.01$ per Kruskal613 Wallis test.

614 (D) Graph showing percentage of cells extruded after vehicle treatment or HU 615 treatment that are apoptotic as per Trypan blue uptake. Each data point 616 represents a separate experiment. Error bars, standard deviation. n.s., not 617 significant per Mann-Whitney test.

618 (E) Graph showing the number of HU-treated or vehicle-treated extruded cells 619 that adhered at $2 \mathrm{~h}$ and $24 \mathrm{~h}$ after reseeding in fresh media. Each data point 
bioRxiv preprint doi: https://doi.org/10.1101/839845; this version posted November 13, 2019. The copyright holder for this preprint (which was not certified by peer review) is the author/funder, who has granted bioRxiv a license to display the preprint in perpetuity. It is made available under aCC-BY-NC-ND 4.0 International license.

620 represents a separate experiment. Error bars, standard deviation. n.s., not

621 significant; ${ }^{* * *}, p<0.0001$ per standard one-way ANOVA.

622 
bioRxiv preprint doi: https://doi.org/10.1101/839845; this version posted November 13, 2019. The copyright holder for this preprint (which was not certified by peer review) is the author/funder, who has granted bioRxiv a license to display the preprint in perpetuity. It is made available

Figure 7

A

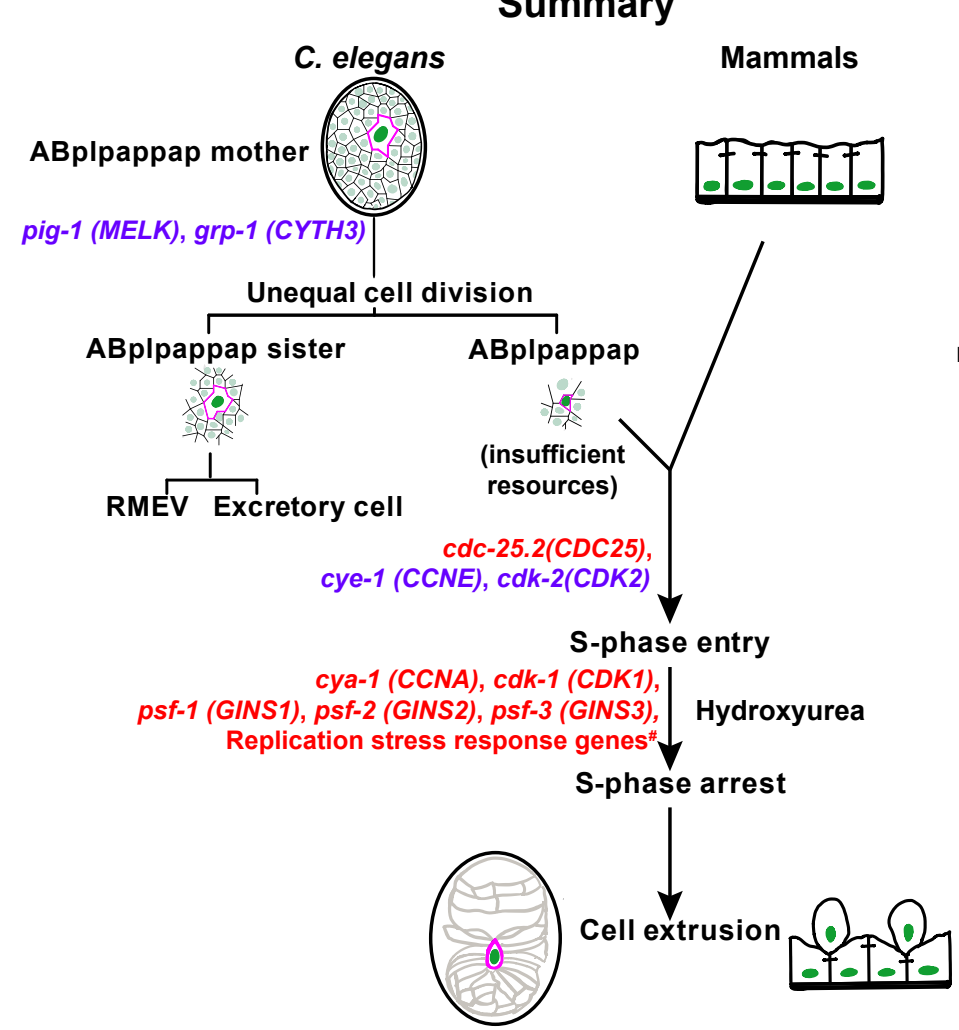

B

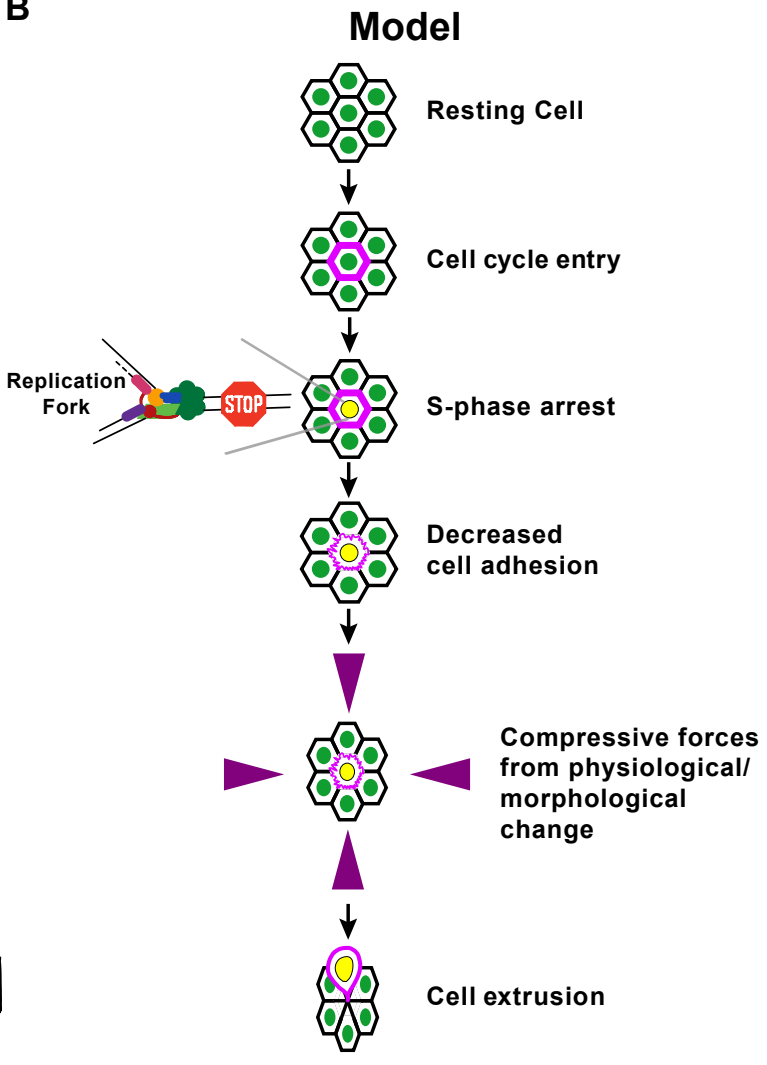

\#atl-1 (ATR), chk-1(CHEK1), clsp-1 (CLSPN), mus-101 (TOPBP1), tim-1 (TIMELESS), tipn-1 (TIPIN), hpr-9 (RAD9) 


\section{Figure 7 Summary and Model: S-phase arrest drives cell extrusion}

624 (A) A summary of the genes required for cell extrusion by $C$. elegans, their

625 mammalian homologs (in parentheses) and their associated biological processes

626 that precede the S-phase arrest that drives the cell extrusion of ABplpappap (and

627 other extruded cells) from C. elegans embryos. Treatment of mammalian cells

628 (MDCK) with HU chemically produces an S-phase arrest in cells that drives their

629 extrusion from simple epithelial layers, as shown. At each step preceding cell

630 extrusion by $C$. elegans, genes with function we demonstrated to occur at the

631 corresponding step are shown in purple, and genes with probable function at that

632 step are shown in red. Relevant cells in the C. elegans embryos are outlined in

633 magenta. The horizontal hyphen-like lines connecting mammalian cells indicate

634 adhesion junctions.

635 (B) Model: A cell that enters the cell cycle (marked by magenta cell boundary)

636 but arrests in S phase (marked by yellow nucleus) will have lowered cell

637 adhesion (marked by wavy magenta cell boundary). When a cell with lowered

638 cell adhesion caused by S-phase arrest experiences morphological or

639 physiological forces (marked by purple arrows) that cause a squeezing-like 640 effect, the cell gets extruded.

641 
bioRxiv preprint doi: https://doi.org/10.1101/839845; this version posted November 13, 2019. The copyright holder for this preprint (which was not certified by peer review) is the author/funder, who has granted bioRxiv a license to display the preprint in perpetuity. It is made available

Supplemental Table " 1

\begin{tabular}{|c|c|c|c|c|c|c|c|c|c|}
\hline RNAi target & $\begin{array}{c}\text { Mammalian } \\
\text { Homolog }\end{array}$ & $\%$ Tex & $\mathrm{n}$ & $\begin{array}{l}\text { extensive } \\
\text { lethality? }\end{array}$ & RNAi target & $\begin{array}{c}\text { Mammalian } \\
\text { Homolog }\end{array}$ & $\%$ Tex & $\mathrm{n}$ & \begin{tabular}{|l} 
extensive \\
lethality?
\end{tabular} \\
\hline empty vector & - & 1 & 159 & $\mathrm{~N}$ & cic-1 & CCNC & 1 & 158 & $\mathrm{~N}$ \\
\hline atl-1 & ATR & 10 & 509 & $\mathrm{~N}$ & cyd-1 & CCND & 0 & 111 & $\mathrm{~N}$ \\
\hline$c d c-14$ & CDC14 & 1 & 168 & $\mathrm{~N}$ & cye-1 & CCNE & 89 & 133 & $Y$ \\
\hline$c d c-25.1$ & CDC25 & 0 & 111 & Y & cyh-1 & $\mathrm{CCNH}$ & 0 & 119 & $Y$ \\
\hline$c d c-25.2$ & CDC25 & 12 & 159 & $\mathrm{~N}$ & cyl-1 & $\mathrm{CCNL}$ & 1 & 106 & $Y$ \\
\hline$c d c-25.3$ & CDC25 & 2 & 168 & $\mathrm{~N}$ & cy $y-1$ & CCNY & 1 & 108 & $\mathrm{~N}$ \\
\hline$c d c-25.4$ & CDC25 & 0 & 183 & $\mathrm{~N}$ & $d p /-1$ & TFDP1 & 0 & 167 & $N$ \\
\hline$c d k-1$ & CDK1 & 15 & 61 & $Y$ & efl-1 & $\mathrm{E} 2 \mathrm{~F}$ & 0 & 141 & $\mathrm{~N}$ \\
\hline$c d k-11.1$ & CDK11 & 0 & 175 & $\mathrm{~N}$ & emb-27 & $\mathrm{CDC} 16$ & 0 & 107 & Y \\
\hline$c d k-11.2$ & CDK11 & 1 & 132 & $\mathrm{~N}$ & emb-30 & ANAPC4 & 0 & 130 & $Y$ \\
\hline$c d k-12$ & CDK12 & 0 & 167 & $\mathrm{~N}$ & $f z r-1$ & FZR1 & 1 & 146 & $\mathrm{~N}$ \\
\hline$c d k-2$ & CDK2 & 65 & 181 & $\mathrm{~N}$ & $f z y-1$ & CDC20 & 0 & 130 & $Y$ \\
\hline$c d k-4$ & CDK4 & 1 & 193 & $N$ & hpr-17 & RAD17 & 5 & 214 & $N$ \\
\hline$c d k-5$ & CDK5 & 0 & 155 & $\mathrm{~N}$ & hus-1 & HUS1 & 0 & 132 & $\mathrm{~N}$ \\
\hline$c d k-7$ & CDK7 & 0 & 130 & $Y$ & lin-15 & - & 1 & 104 & $\mathrm{~N}$ \\
\hline$c d k-8$ & CDK8 & 1 & 186 & $N$ & Iin-23 & $\beta \operatorname{TrCP}$ & 23 & 147 & $N$ \\
\hline$c d k-9$ & CDK9 & 1 & 155 & $Y$ & lin-35 & $\mathrm{Rb}$ & 0 & 134 & $N$ \\
\hline$c d t-1$ & CDT1 & 1 & 147 & $Y$ & lin-36 & - & 0 & 111 & $\mathrm{~N}$ \\
\hline chk-1 & CHEK1 & 10 & 164 & $Y$ & $\operatorname{lin}-9$ & LIN9 & 1 & 125 & $\mathrm{~N}$ \\
\hline cit-1.1 & CCNT1/2 & 0 & 105 & $\mathrm{~N}$ & mat-1 & CDC27 & 0 & 80 & $Y$ \\
\hline cit-1.2 & CCNT1/2 & 1 & 244 & $N$ & mat-2 & ANAPC1 & 1 & 163 & $Y$ \\
\hline$c k i-1$ & CDKN1 & 0 & 125 & $\mathrm{~N}$ & mat-3 & CDC23 & 0 & 108 & $Y$ \\
\hline cki-2 & CDKN1 & 1 & 216 & $\mathrm{~N}$ & $m d f-1$ & MAD1L1 & 3 & 112 & $\mathrm{~N}$ \\
\hline clk-2 & TELO2 & 1 & 156 & $N$ & $m d f-2$ & MAD2L1 & 1 & 111 & $N$ \\
\hline cul-1 & CUL1 & 5 & 81 & $Y$ & $m r t-2$ & RAD1 & 0 & 114 & $\mathrm{~N}$ \\
\hline cul-2 & CUL2 & 0 & 21 & Y & $r n r-1$ & RRM1 & 5 & 103 & Y \\
\hline cul-3 & CUL3 & 5 & 151 & Y & san-1 & BUB1B & 1 & 145 & $\mathrm{~N}$ \\
\hline cul-4 & CUL4 & 0 & 141 & $\mathrm{~N}$ & wee-1.1 & PKMYT1 & 1 & 159 & $\mathrm{~N}$ \\
\hline cya-1 & CCNA & 20 & 309 & $N$ & wee-1.3 & PKMYT1 & 0 & 60 & $Y$ \\
\hline$c y b-1$ & CCNB1 & 4 & 136 & $\mathrm{~N}$ & & & & & \\
\hline$c y b-2.1$ & CCNB2 & 1 & 102 & $N$ & & & & & \\
\hline$c y b-2.2$ & CCNB2 & 0 & 144 & $\mathrm{~N}$ & & & & & \\
\hline$c y b-3$ & CCNB3 & 14 & 7 & Y & & & & & \\
\hline
\end{tabular}


642 Supplemental Table 1 Penetrance of the Tex phenotype produced by RNAi 643 against cell cycle genes (and non-cell-cycle cyclins and CDKs) in ced-3(If)

644 animals. Tex penetrance produced by each of the RNAi clones in the cell-cycle 645 RNAi library, the number of animals counted for each RNAi clone and whether or 646 not the RNAi clone produced extensive lethality are shown. Genes corresponding 647 to RNAi clones that produced more than 9\% penetrance of the Tex phenotype 648 are in bold. cyb-3 did not fit this criterion, as extensive lethality prevented the 649 counting of sufficient number of animals to assign significance. Some cyclins and 650 CDKs that function outside the cell cycle were included in this library and served 651 as negative controls.

652 


\section{Supplemental Table 2}

\begin{tabular}{c|c|c|c}
\hline RNAi target & $\begin{array}{c}\text { Mammalian } \\
\text { Homolog }\end{array}$ & \%Tex & $\mathrm{n}$ \\
\hline empty vector & - & 0 & 127 \\
atl-1 & ATR & 0 & 198 \\
cdc-25.2 & CDC25 & 0 & 36 \\
cdk-1 & CDK1 & 0 & 51 \\
cdk-2 & CDK2 & 0 & 237 \\
chk-1 & CHK1 & 0 & 115 \\
csn-1 & GPS1 & 0 & 156 \\
csn-4 & COPS4 & 0 & 141 \\
csn-5 & COPS5 & 0 & 114 \\
cya-1 & CCNA & 0 & 167 \\
cye-1 & CCNE & 0 & 143 \\
lin-23 & BTrCP & 12 & 96 \\
psf-1 & GINS1 & 0 & 150 \\
psf-2 & GINS2 & 0 & 190 \\
psf-3 & GINS3 & 0 & 72 \\
\hline
\end{tabular}


653 Supplemental Table 2 Penetrance of the Tex phenotype produced in wild-

654 type animals by RNAi against cell cycle genes with potential roles in cell

655 extrusion. The Tex penetrance produced in wild-type animals by RNAi clones

656 against cell cycle genes that might be involved in cell extrusion (based on the

657 corresponding Tex penetrance in ced-3(If) animals) is provided. Bona fide

658 candidates for cell extrusion regulation should not produce a Tex phenotype in

659 wild-type animals, as cell extrusion does not occur in wild-type worms. A Tex

660 phenotype in wild-type animals could occur from other effects of RNAi against

661 cell cycle genes, such as excessive proliferation leading to multiple excretory

662 cells. Such proliferation is likely the case for lin-23, as RNAi against lin-23 has

663 been previously described to cause excessive proliferation (Kipreos et al., 2000).

664 The 13 other genes are good candidates to be regulators of cell extrusion by the

665 criterion of dependence of the Tex phenotype on the loss of function of ced-3. 


\section{Supplemental Figure 1}
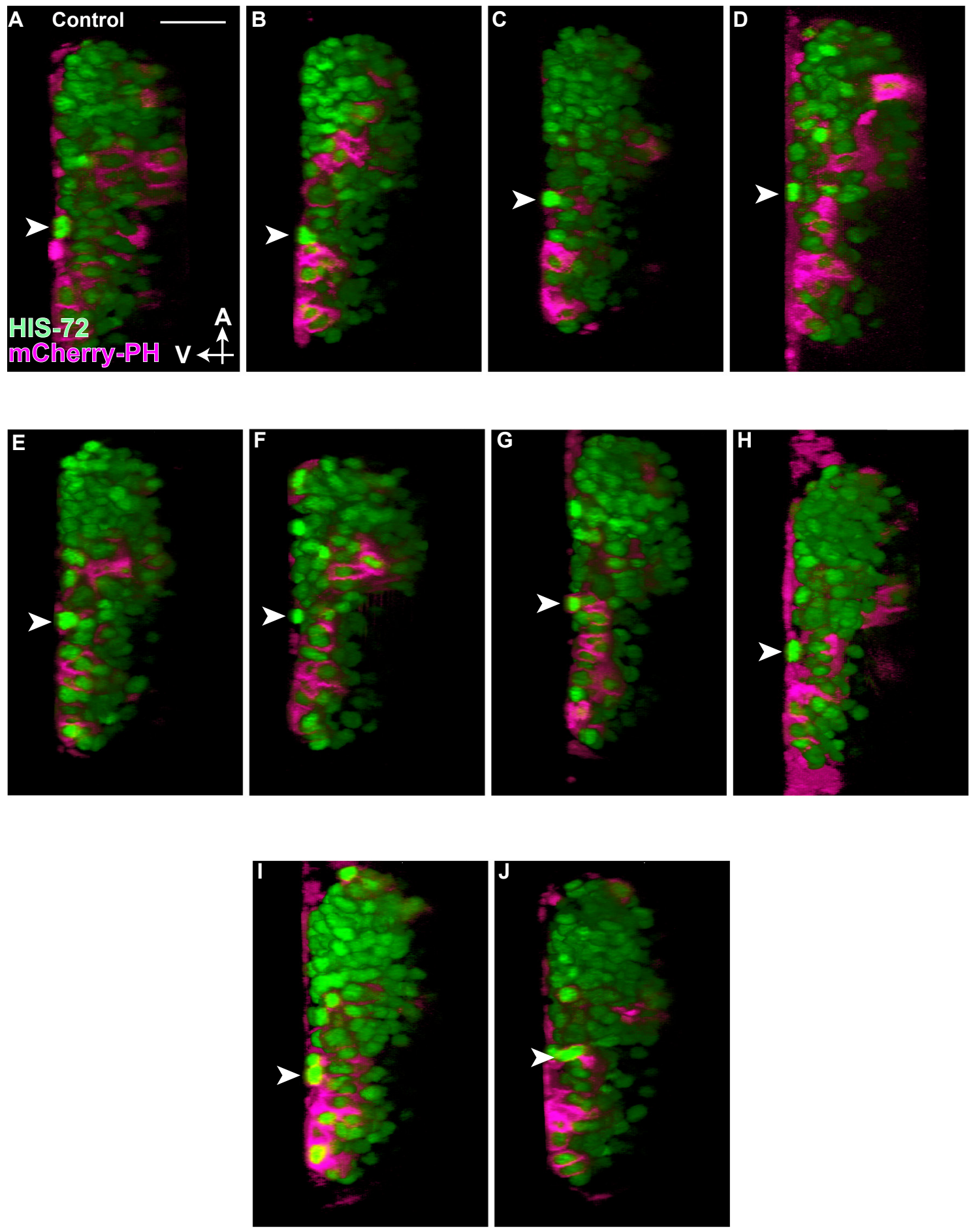


\section{Supplemental Figure 1 ABplpappap is extruded by control embryos}

667 (A-J) Virtual lateral sections of embryos through the ABplpappap cell (arrowhead)

668 in (A-J) 10 control embryos show (A-I) ABplpappap is extruded in 9 of 10

669 embryos and $(\mathrm{J})$ is not extruded in 1 of 10 embryos. The embryos shown carry

670 the transgenes st/s10026 and $n / s 861$. A, anterior; V, ventral. Scale bar, $10 \mu \mathrm{m}$.

671 
bioRxiv preprint doi: https://doi.org/10.1101/839845; this version posted November 13, 2019. The copyright holder for this preprint (which was not certified by peer review) is the author/funder, who has granted bioRxiv a license to display the preprint in perpetuity. It is made available under aCC-BY-NC-ND 4.0 International license.

\section{Supplemental Figure 2}
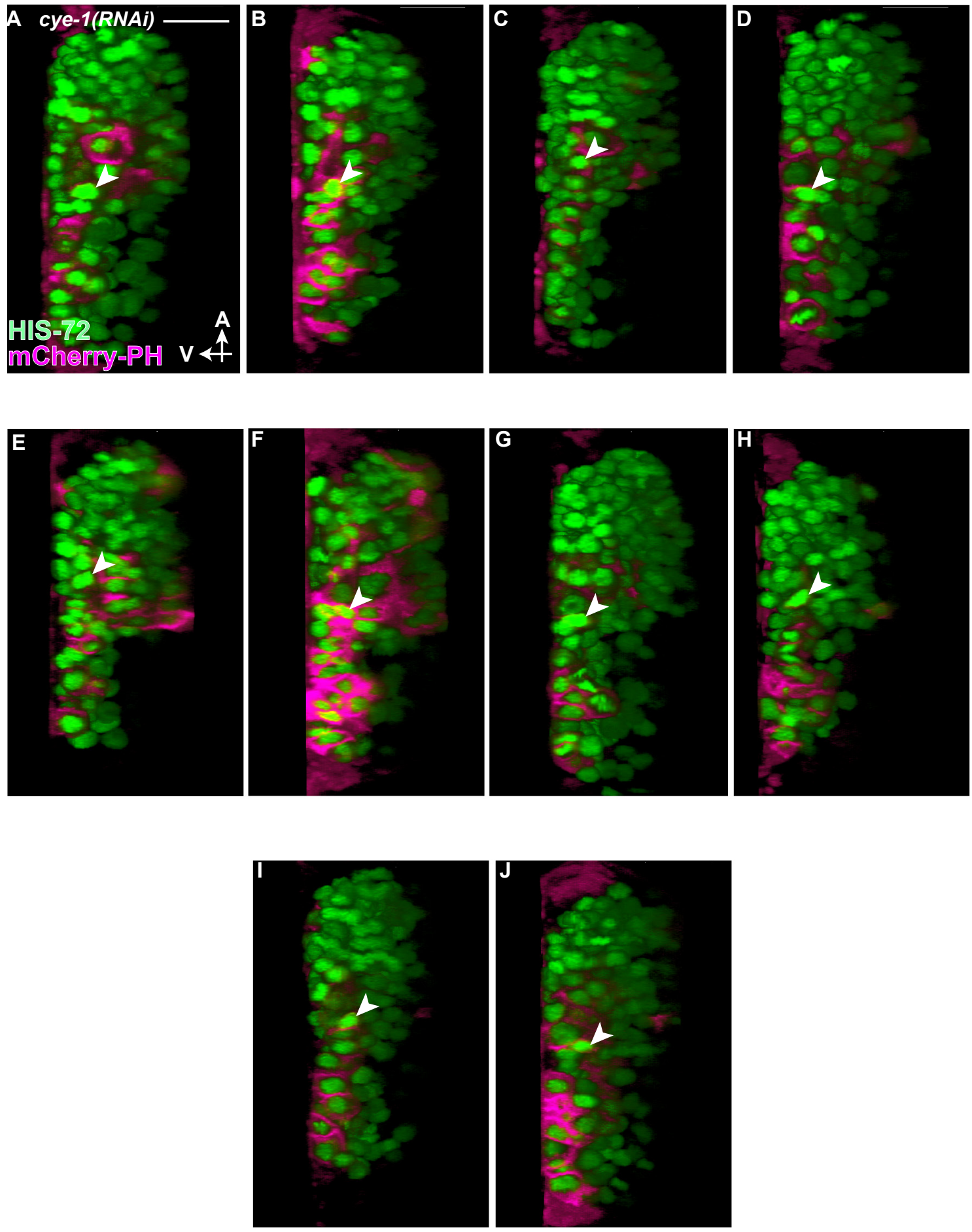
672 Supplemental Figure 2 ABplpappap is not extruded by cye-1(RNAi)

673 embryos

674 (A-J) Virtual lateral sections of embryos through the ABplpappap cell (arrowhead)

675 in (A-J) 10 cye-1(RNAi) embryos show that ABplpappap is not extruded in 10 of

67610 embryos. The embryos shown carry the transgenes st/s10026 and $n / s 861$. A,

677 anterior; $\mathrm{V}$, ventral. Scale bar, $10 \mu \mathrm{m}$.

678 
bioRxiv preprint doi: https://doi.org/10.1101/839845; this version posted November 13, 2019. The copyright holder for this preprint (which was not certified by peer review) is the author/funder, who has granted bioRxiv a license to display the preprint in perpetuity. It is made available under aCC-BY-NC-ND 4.0 International license.

\section{Supplemental Figure 3}
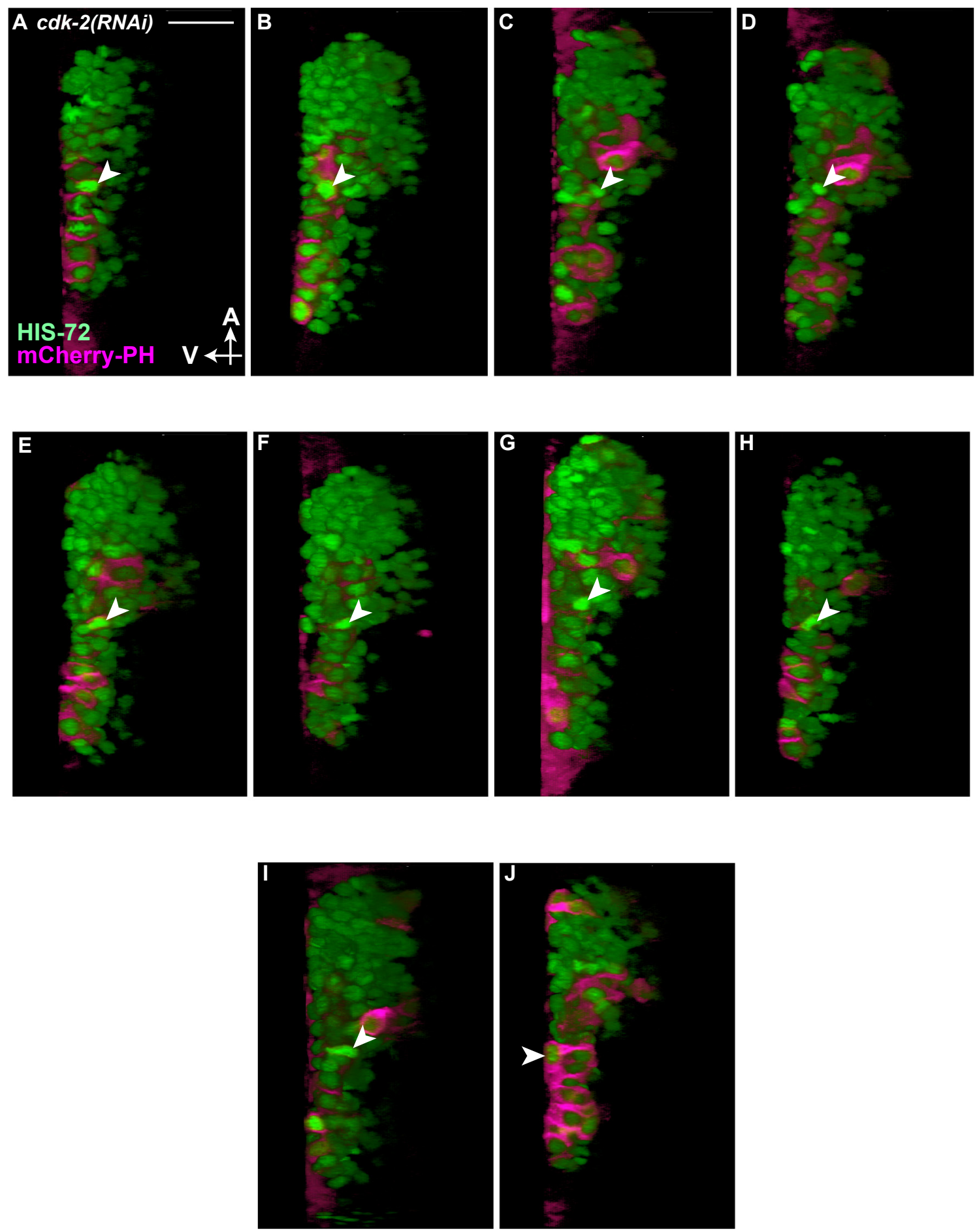
679 Supplemental Figure 3 ABplpappap is not extruded by cdk-2(RNAi)

680 embryos

681 (A-J) Virtual lateral sections of embryos through the ABplpappap cell (arrowhead)

682 in (A-J) 10 cdk-2(RNAi) embryos show that (A-I) ABplpappap is not extruded in 9

683 of 10 embryos and $(\mathrm{J})$ is extruded in 1 of 10 embryos. The embryos shown carry

684 the transgenes st/s10026 and $n / s 861$. A, anterior; V, ventral. Scale bar, $10 \mu \mathrm{m}$.

685 
bioRxiv preprint doi: https://doi.org/10.1101/839845; this version posted November 13, 2019. The copyright holder for this preprint (which was not certified by peer review) is the author/funder, who has granted bioRxiv a license to display the preprint in perpetuity. It is made available under aCC-BY-NC-ND 4.0 International license.

\section{Supplemental Figure 4}

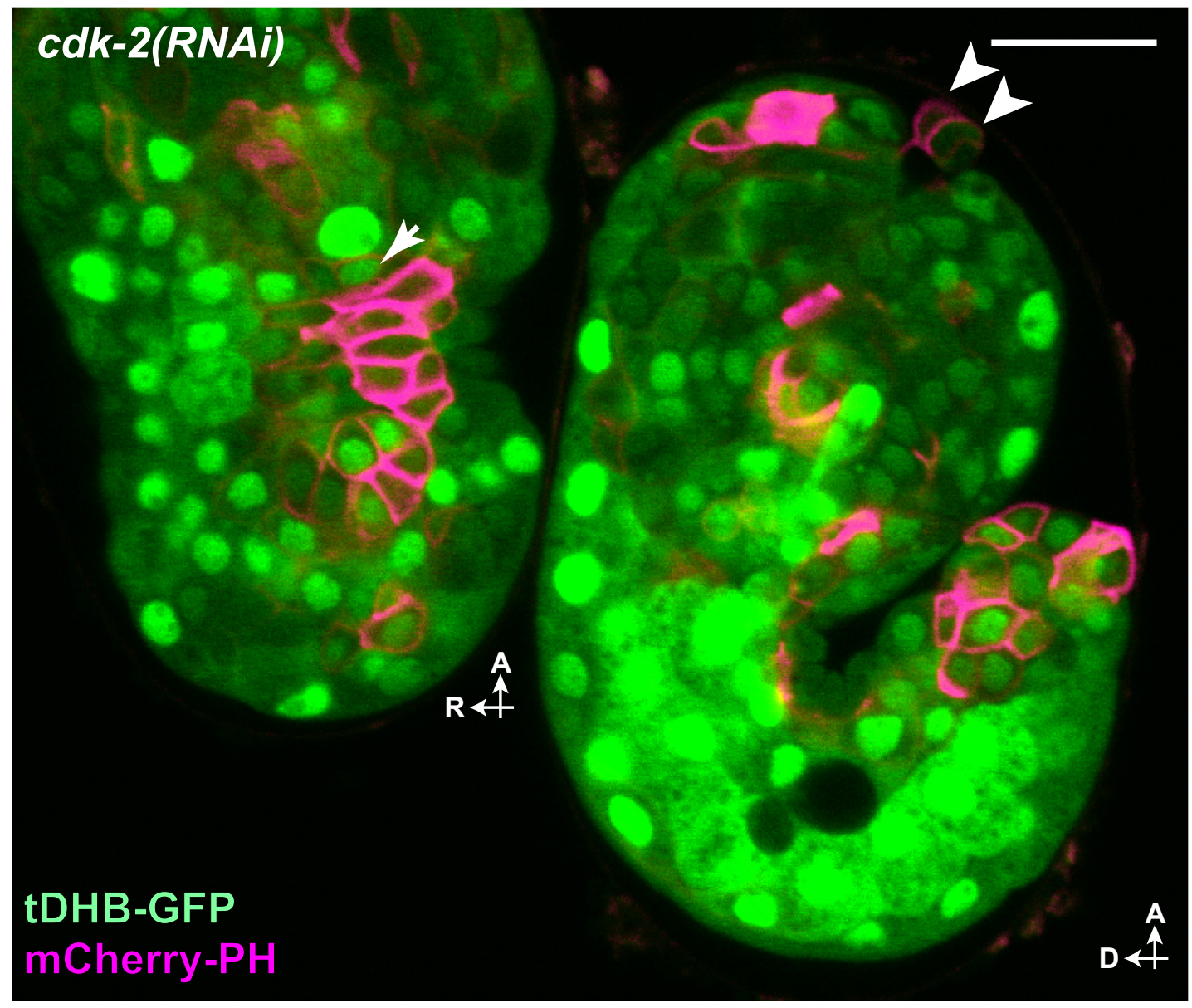


686 Supplemental Figure 4 Cells extruded by $c d k$-2(RNAi) embryos enter the 687 cell cycle

688 Micrograph of two $c d k-2(R N A i)$ embryos expressing tDHB-GFP shows a nuclear689 enriched localization of tDHB-GFP in an ABplpappap cell (arrow) that was not 690 extruded by the first embryo but presumably nuclear-depleted tDHB-GFP in two 691 cells that were extruded from the second embryo (arrowheads). The embryos 692 shown carry the transgenes heSi192 and nls861. A, anterior; D, dorsal; R, right. 693 Scale bar, $10 \mu \mathrm{m}$.

694 


\section{Supplemental Figure 5}

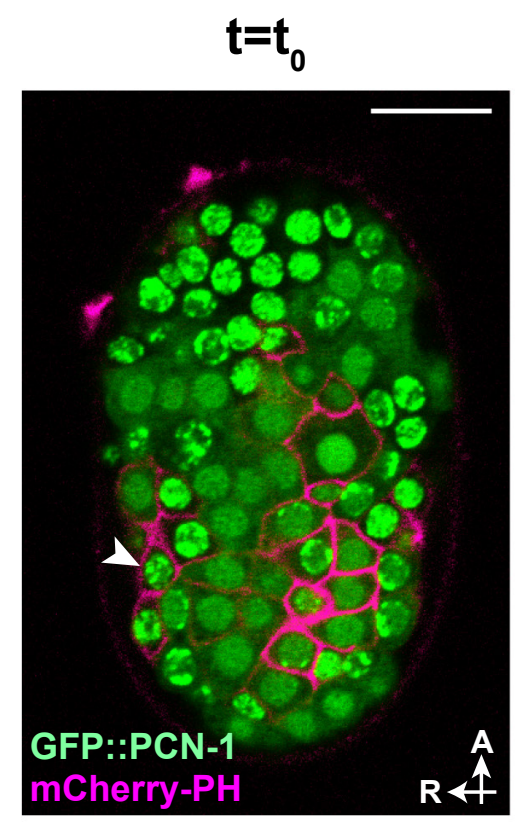

$\mathrm{t}=\mathrm{t}_{0}+5$ mins

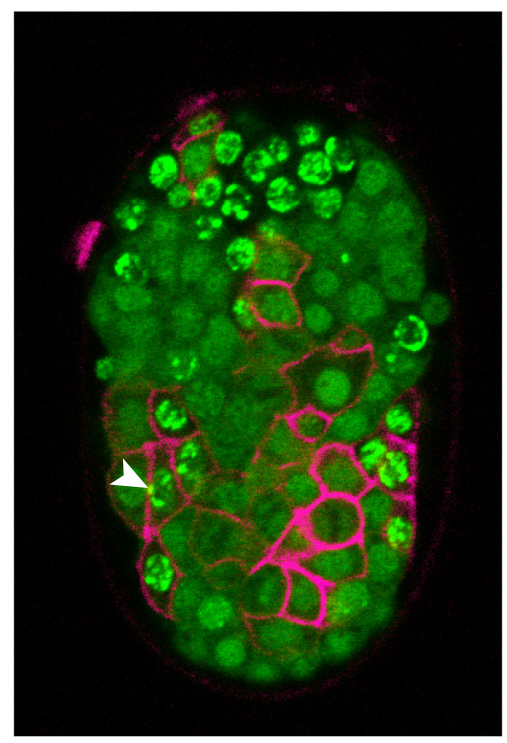

$t=t_{0}+20$ mins
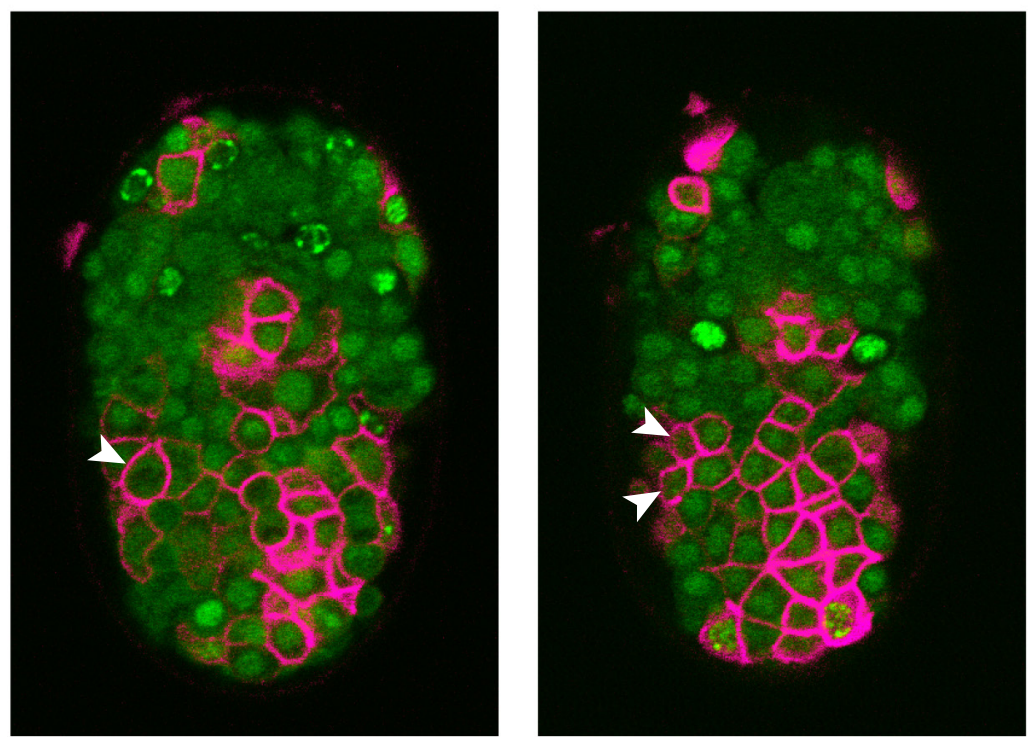

$t=t_{0}+10$ mins

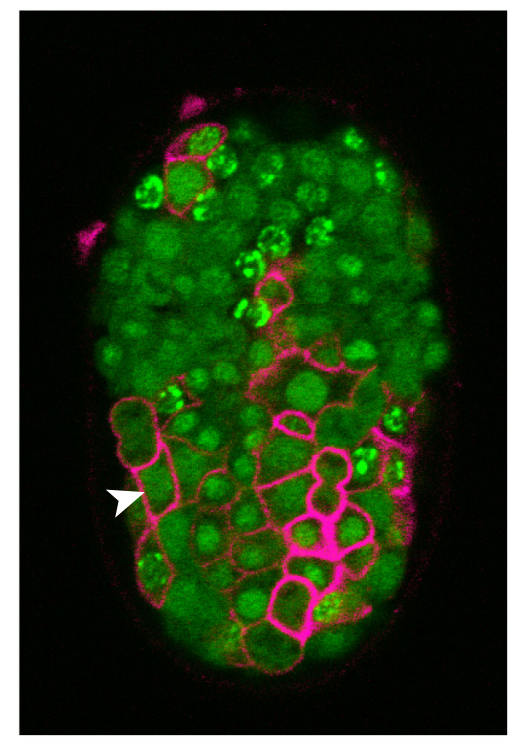

$t=t_{0}+25$ mins

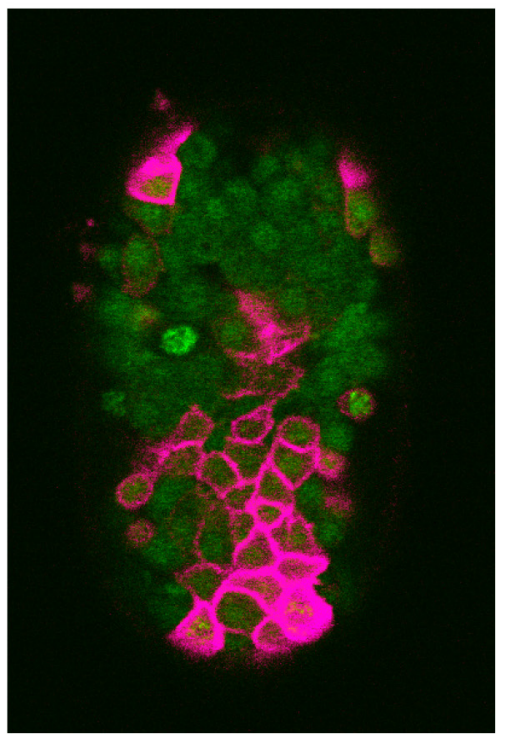


695 Supplemental Figure 5 GFP::PCN-1 exhibits a localization pattern 696 coordinated with the cell cycle in embryonic cells on the ventral surface

697 Time-lapse confocal micrographs of a ced-3(If) embryo obtained at 5-min 698 intervals show the dynamics of GFP::PCN-1 localization in multiple cells on the

699 ventral surface of the embryo. Arrowheads mark a cell that is shown undergoing 700 a complete cell cycle. The embryo shown carries the transgenes is/s17 and 701 n/s861. A, anterior; R, right. Scale bar, $10 \mu \mathrm{m}$.

702 
bioRxiv preprint doi: https://doi.org/10.1101/839845; this version posted November 13,2019 . The copyright holder for this preprint (which was not certified by peer review) is the author/funder, who has granted bioRxiv a license to display the preprint in perpetuity. It is made available Supplemental Figure 6

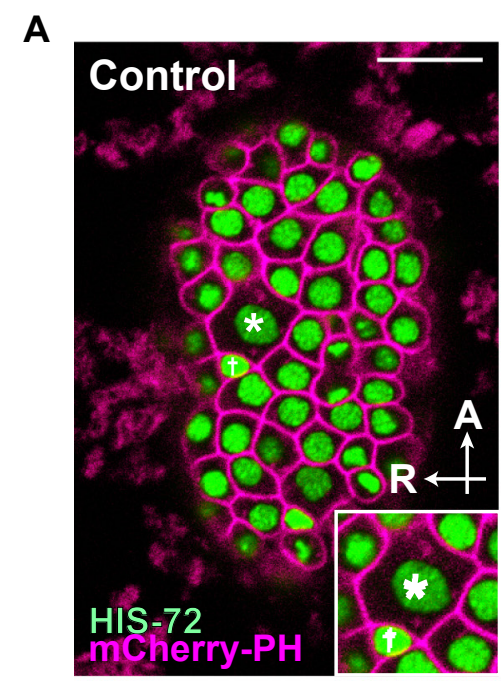

B

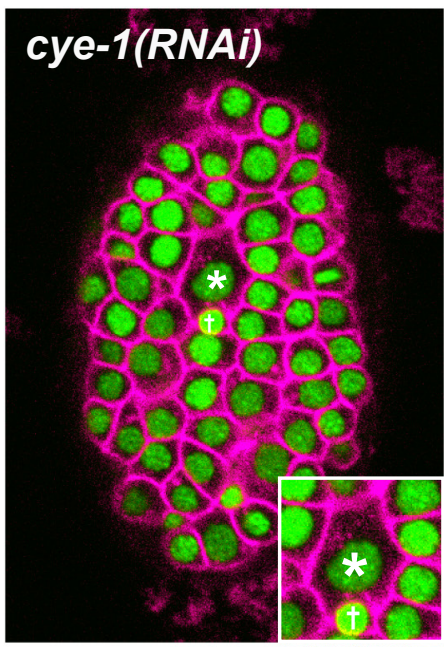

D

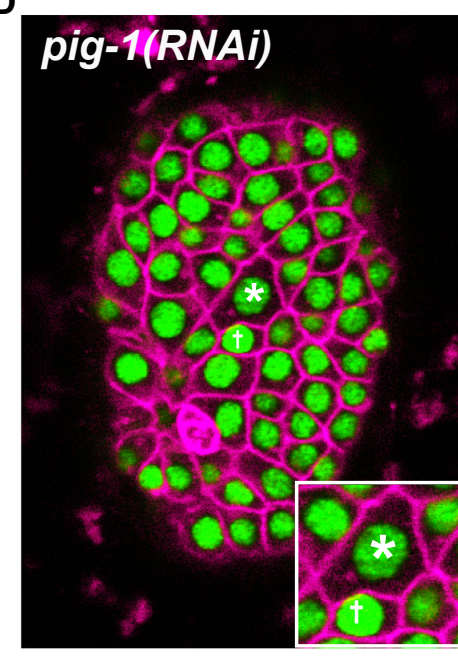

\section{C}

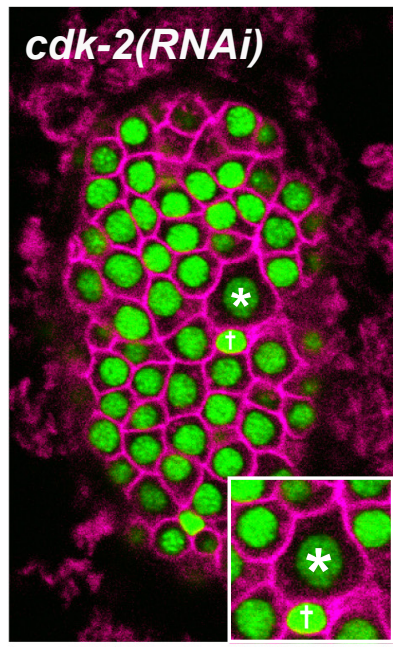

E

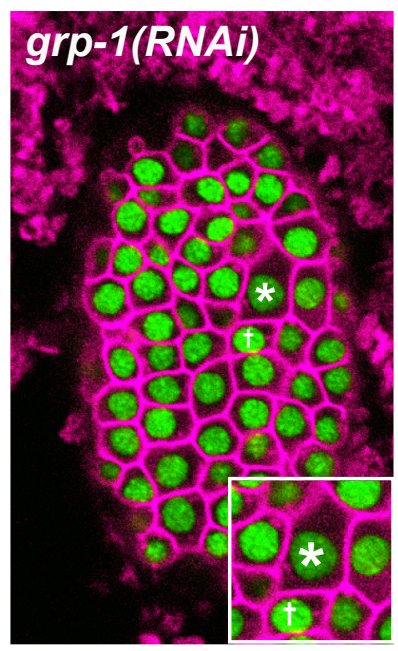




\section{Supplemental Figure 6 ABplpappa undergoes unequal cell division}

\section{4 controlled by pig-1 and grp-1 but independent of cye-1 and cdk-2}

705 Micrographs of ced-3(If) embryos expressing nuclear GFP and membrane-

706 localized mCherry in all cells obtained using confocal microscopy show the

707 relative sizes of ABplpappap (†) and its sister, ABplpappaa $\left(^{*}\right)$ in a $(A)$ control

708 embryo, (B) cye-1(RNAi) embryo, (C) cdk-2(RNAi) embryo, (D) pig-1(RNAi)

709 embryo and (E) grp-1(RNAi) embryo. Inset, a magnified view of ABplpappap(†)

710 and its sister, ABplpappaa $\left({ }^{*}\right)$. All embryos shown carried the transgenes

711 st/s10026 and It/s44[P pie-1::mCherry::PH], which expresses membrane-localized

$712 \mathrm{mCherry}$ in all cells. A, anterior; R, right. Scale bar, $10 \mu \mathrm{m}$.

713

714 


\section{Supplemental Movies}

716 Movie 1 Control embryos extrude ABplpappap as it undergoes ventral

\section{7 enclosure}

718 Time-lapse video of a ced-3(If); control(RNAi) embryo undergoing ventral

719 enclosure over a period of 50 minutes shows ABplpappap (circled at the

720 beginning and end of video) was extruded from this embryo. All nuclei are

721 labeled with GFP and membranes of egl-1-expressing cells are labeled with

722 mCherry (magenta). Time-lapse images used for this video were obtained using

723 confocal microcopy. Video playback is at $600 x$ real speed. The embryo shown

724 carried the transgenes st/s10026 and nls632.

725 Movie 2 cye-1(RNAi) embryos do not extrude ABplpappap as it undergoes

726 ventral enclosure

727 Time-lapse video of a ced-3(If); cye-1(RNAi) embryo undergoing ventral

728 enclosure over a period of 50 minutes shows ABplpappap (circled at the

729 beginning and end of video) was not extruded from this embryo. All nuclei are

730 labeled with GFP and membranes of egl-1-expressing cells are labeled with

731 mCherry (magenta). Time-lapse images used for this video were obtained using

732 confocal microcopy. Video playback is at $600 x$ real speed. The embryo shown

733 carried the transgenes st/s10026 and nls632.

734 Movie 3 cdk-2(RNAi) embryos do not extrude ABplpappap as it undergoes

\section{5 ventral enclosure}

736 Time-lapse video of a ced-3(If); cdk-2 (RNAi) embryo undergoing ventral

737 enclosure over a period of 50 minutes shows ABplpappap (circled at the 
738 beginning and end of video) was not extruded from this embryo. All nuclei are

739 labeled with GFP and membranes of egl-1-expressing cells are labeled with

740 mCherry (magenta). Time-lapse images used for this video were obtained using

741 confocal microcopy. Video playback is at 600x real speed. The embryo shown

742 carried the transgenes st/s10026 and nls632.

743 Movie 4 GFP::PCN-1 shows continuous change in fluorescence intensity

744 during embryonic cell cycles

745 Time-lapse video of a ced-3(If) embryo expressing GFP::PCN-1 in all cells shows

746 continuous change in GFP::PCN-1 fluorescence intensity as cells progress

747 through the cell cycle, similar to that observed for early embryonic cell cycles

748 (Brauchle et al., 2003). Membranes of egl-1-expressing cells are labeled with

749 mCherry (magenta). Time-lapse images used for this video were obtained using

750 confocal microcopy. Video playback is at 180x real speed. The embryo shown

751 carried the transgenes is/s17 and $n / s 861$.

752 Movie 5 ABplpappap divides before ventral enclosure and is not extruded

753 in pig-1(RNAi) embryos

754 Time-lapse video of a ced-3(If); pig-1 (RNAi) embryo undergoing ventral

755 enclosure over a period of 57 minutes shows ABplpappap (circled at the

756 beginning) divided to generate daughters (circled at the end of video) before

757 ventral enclosure was complete in this embryo. All nuclei are labeled with GFP

758 and membranes of egl-1-expressing cells are labeled with mCherry (magenta).

759 Time-lapse images used for this video were obtained using confocal microcopy. 
760 Video playback is at $600 x$ real speed. The embryo shown carried the transgenes

761 st/s10026 and $n / s 861$.

762 Movie 6 A few cells are extruded from a vehicle-treated MDCK monolayer

763 A time-lapse video of mammalian MDCK monolayer treated with vehicle control

764 for $21.25 \mathrm{~h}$ shows that a few cells are extruded during this period. Extruded cells

765 can be identified as bright, white, rounded spots rising from the epithelial plane.

766 Video playback is at 7200x real speed. Scale bar, $100 \mu \mathrm{m}$.

767 Movie 7 A large number of cells are extruded from an HU-treated MDCK

768 monolayer

769 A time-lapse video of mammalian MDCK monolayer exposed to HU for $21.25 \mathrm{~h}$

770 shows that many more cells are extruded during this period as a result of $\mathrm{HU}$

771 treatment. Extruded cells can be identified as bright, white, rounded spots rising

772 from the epithelial plane. Video playback is at $7200 x$ real speed. Scale bar, 100

$773 \mu \mathrm{m}$. 


\section{KEY RESOURCES TABLE}

\begin{tabular}{|c|c|c|}
\hline REAGENT or RESOURCE & SOURCE & IDENTIFIER \\
\hline \multicolumn{3}{|l|}{ Antibodies } \\
\hline \multicolumn{3}{|l|}{ Bacterial and Virus Strains } \\
\hline C. elegans and E. coli strains & This paper & Table S4 \\
\hline \multicolumn{3}{|l|}{ Biological Samples } \\
\hline \multicolumn{3}{|l|}{ Chemicals, Peptides, and Recombinant Proteins } \\
\hline Chemical: Isopropyl- $\beta$-D-thiogalactopyranoside & Amresco & Cat\#0487 \\
\hline Chemical: Hydroxyurea & Millipore Sigma & Cat\#H8627 \\
\hline \multicolumn{3}{|l|}{ Critical Commercial Assays } \\
\hline In-Fusion HD Cloning Assays & TaKaRa & Cat\#639637 \\
\hline QuikChange Site-Directed Mutagenesis Kit & Agilent & Cat\#200515 \\
\hline Phusion High-Fidelity DNA Polymerase & New England Biolabs & Cat\#M0530L \\
\hline Q5 Hot Start High-Fidelity DNA Polymerase & New England Biolabs & Cat\#M0439L \\
\hline \multicolumn{3}{|l|}{ Deposited Data } \\
\hline \multicolumn{3}{|l|}{ Experimental Models: Cell Lines } \\
\hline \multicolumn{3}{|l|}{ Experimental Models: Organisms/Strains } \\
\hline C. elegans and E. coli strains & This Paper & Table S4 \\
\hline \multicolumn{3}{|l|}{ Oligonucleotides } \\
\hline $\begin{array}{l}\text { Forward primer to amplify egl-1 promoter: } \\
\text { CGCctgcagTTGAAATTTGGGGATATTTTGG }\end{array}$ & This Paper & DPD660 \\
\hline $\begin{array}{l}\text { Reverse primer to amplify egl-1 promoter: } \\
\text { CGCgagctcCTGGAAATTAGTAAGGTTTTGAAGGGGG }\end{array}$ & This Paper & DPD661 \\
\hline $\begin{array}{l}\text { Forward primer to amplify mCherry PLC-1ס PH domain: } \\
\text { CGCaccggtCCAGATGGCTCAAACAAAGC }\end{array}$ & This Paper & DPD647 \\
\hline $\begin{array}{l}\text { Reverse primer to amplify mCherry PLC- } 1 \delta \text { PH domain: } \\
\text { CGCgaattcGGCACAAGTTCATTCACAGG }\end{array}$ & This Paper & DPD648 \\
\hline $\begin{array}{l}\text { Forward primer to remove NLS sequence: } \\
\text { ggagctcAGAAAAAATGGTCTCAAAGGGTG }\end{array}$ & This Paper & DPD695 \\
\hline $\begin{array}{l}\text { Reverse primer to remove NLS sequence: } \\
\text { CACCCTTTGAGACCATTTTTTCTgagctcc }\end{array}$ & This Paper & DPD696 \\
\hline $\begin{array}{l}\text { Forward primer to amplify atl-1 genomic region for RNAi: } \\
\text { TCGAATTCCTGCAGCTCCTCGAACCCATCATCCCT }\end{array}$ & This Paper & RD105 \\
\hline $\begin{array}{l}\text { Reverse primer to amplify atl-1 genomic region for RNAi: } \\
\text { TGACGCGTGGATCCCATGAAGCTGCGTGGTTGTTG }\end{array}$ & This Paper & RD106 \\
\hline $\begin{array}{l}\text { Forward primer to amplify mat-2 genomic region for } \\
\text { RNAi: } \\
\text { TCGAATTCCTGCAGCCTGGAACTCATCCCATACGC }\end{array}$ & This Paper & RD103 \\
\hline $\begin{array}{l}\text { Reverse primer to amplify mat-2 genomic region for } \\
\text { RNAi: } \\
\text { TGACGCGTGGATCCCCATTGGAACCTCCAGATGCT }\end{array}$ & This Paper & RD104 \\
\hline Additional oligonucleotides & This Paper & Table S3 \\
\hline \multicolumn{3}{|l|}{ Recombinant DNA } \\
\hline pDD111 - $P_{\text {egl-1::mCherry::PH::unc-54 3'UTR }}$ & This Paper & $\mathrm{N} / \mathrm{A}$ \\
\hline pL4440 - atl-1 & This Paper & $\mathrm{N} / \mathrm{A}$ \\
\hline
\end{tabular}


bioRxiv preprint doi: https://doi.org/101101/839845; this version posted November 13,2019 . The copyright holder for this preprint (which was not certified by peer review) is the author/funder, who has granted bioRxiv a license to display the preprint in perpetuity. It is made available under aCC-BY-NC-ND 4.0 International license.

\begin{tabular}{|c|c|c|}
\hline pL4440 - mat-2 & This Paper & N/A \\
\hline pL4440 - lin-15B & This Paper & N/A \\
\hline pAA173 & Ziel et al., 2009 & N/A \\
\hline pPD122.56 & Andrew Fire & $\begin{array}{l}\text { L4054, } \\
\text { RRID:Addgene_1632 }\end{array}$ \\
\hline p76-16B & $\begin{array}{l}\text { Bloom and Horvitz, } \\
1997\end{array}$ & $\mathrm{~N} / \mathrm{A}$ \\
\hline pML902 & McMahon et al., 2001 & N/A \\
\hline \multicolumn{3}{|l|}{ Software and Algorithms } \\
\hline ImageJ & $\mathrm{NIH}$ & $\begin{array}{l}\text { https://imagej.nih.go } \\
\text { v/ij/ }\end{array}$ \\
\hline GraphPad Prism 7 & GraphPad Software & $\begin{array}{l}\text { https://www.graphpa } \\
\text { d.com/scientific- } \\
\text { software/prism/ }\end{array}$ \\
\hline Zen Blue & Zeiss & $\frac{\text { https://www.zeiss.co }}{\frac{\mathrm{m} / \mathrm{microscopy} / \mathrm{us} / \mathrm{do}}{\text { wnloads/zen.html }}}$ \\
\hline Adobe Photoshop and Illustrator & Adobe & $\begin{array}{l}\text { https://www.adobe. } \\
\text { com/creativecloud.h } \\
\text { tml }\end{array}$ \\
\hline Geneious 10.2 .6 & Biomatters, Inc. & $\begin{array}{l}\text { https://www.geneio } \\
\text { us.com/ }\end{array}$ \\
\hline Stowers ImageJ Plugin & Jay Unruh & $\begin{array}{l}\text { https://research.sto } \\
\text { wers.org/imagejplug } \\
\text { ins/index.html }\end{array}$ \\
\hline \multicolumn{3}{|l|}{ Other } \\
\hline & & \\
\hline & & \\
\hline & & \\
\hline
\end{tabular}


bioRxiv preprint doi: https://doi.org/10.1101/839845; this version posted November 13 2019. The copyright holder for this preprint (which was not certified by peer review) is the author/funder, who has granted bioRxiv a license to display the preprint in perpetuity. It is made available under aCC-BY-NC-ND 4.0 International license.

Table S3. Additional Oligonucleotides.

REAGENT OR RESOURCE

SOURCE IDENTIFIER

Forward primer to amplify lin-15B genomic DNA for RNAi:

TCGAATTCCTGCAGCGCTGACACAATTGCGAACAT

This paper RD101

Reverse primer to amplify lin-15B genomic DNA for RNAi:

TGACGCGTGGATCCCCGTGTGCATAAAGACCAAGG

This paper RD102 
Table S4. C. elegans and E. coli strains.

\begin{tabular}{|c|c|c|}
\hline REAGENT OR RESOURCE & SOURCE & IDENTIFIER \\
\hline C. elegans Strain: Bristol N2 & $\begin{array}{l}\text { Caenorhabditis Genetics } \\
\text { Center }\end{array}$ & $\mathrm{N} 2$ \\
\hline C. elegans Strain OD70: unc-119(ed3) III; It/s44 V & $\begin{array}{l}\text { Caenorhabditis Genetics } \\
\text { Center, Kachur et al., } \\
\text { (2008) }\end{array}$ & $\begin{array}{l}\text { OD70; } \\
\text { RRID:WB- } \\
\text { STRAIN:OD70 }\end{array}$ \\
\hline C. elegans Strain GZ264: unc-1 19(ed3) III; is/s 17 & $\begin{array}{l}\text { Caenorhabditis Genetics } \\
\text { Center, Brauchle et al. } \\
\text { (2003) }\end{array}$ & $\begin{array}{l}\text { GZ264; } \\
\text { RRID:WB- } \\
\text { STRAIN:GZ264 }\end{array}$ \\
\hline $\begin{array}{l}\text { C. elegans Strain SV1668: heSi192 II; unc- } \\
\text { 119(ed3) III }\end{array}$ & van Rijnberk et al. (2017) & $\mathrm{N} / \mathrm{A}$ \\
\hline C. elegans Strain RW10026: stls 10026 & $\begin{array}{l}\text { Caenorhabditis Genetics } \\
\text { Center, Boeck et al., (2011) }\end{array}$ & $\begin{array}{l}\text { RW10026; } \\
\text { RRID:WB- } \\
\text { STRAIN:RW100 } \\
26\end{array}$ \\
\hline $\begin{array}{l}\text { C. elegans Strain MT8034: ced-3(n717) IV; unc- } \\
\text { 76(e911) V }\end{array}$ & This paper & $\mathrm{N} / \mathrm{A}$ \\
\hline C. elegans Strain MT12054: ced-3(n3692) IV & Denning et al. (2012) & $\mathrm{N} / \mathrm{A}$ \\
\hline C. elegans Strain MT20083: nls433 I & Denning et al. (2012) & $\mathrm{N} / \mathrm{A}$ \\
\hline $\begin{array}{l}\text { C. elegans Strain MT20117: nls433 I; ced- } \\
\text { 3(n3692) IV }\end{array}$ & Denning et al. (2012) & N/A \\
\hline $\begin{array}{l}\text { C. elegans Strain MT22348: ced-3(n717) IV; unc- } \\
\text { 76(e911) V; } n E \times 2188\end{array}$ & This paper & $\mathrm{N} / \mathrm{A}$ \\
\hline $\begin{array}{l}\text { C. elegans Strain MT22380: ced-3(n717) IV; unc- } \\
\text { 76(e911) V; nls632 }\end{array}$ & This paper & $\mathrm{N} / \mathrm{A}$ \\
\hline $\begin{array}{l}\text { C. elegans Strain MT22450: ced-3(n3692) IV; } \\
\text { stls 10026; nls632 }\end{array}$ & This paper & $\mathrm{N} / \mathrm{A}$ \\
\hline $\begin{array}{l}\text { C. elegans Strain MT25568: ced-3(n3692) IV; } \\
\text { nls861 }\end{array}$ & This paper & $\mathrm{N} / \mathrm{A}$ \\
\hline $\begin{array}{l}\text { C. elegans Strain MT25639: ced-3(n3692) IV; } \\
\text { stls 10026; nIs861 }\end{array}$ & This paper & $\mathrm{N} / \mathrm{A}$ \\
\hline $\begin{array}{l}\text { C. elegans Strain MT25640: heSi192 II; ced- } \\
\text { 3(n3692) IV; nls861 }\end{array}$ & This paper & $\mathrm{N} / \mathrm{A}$ \\
\hline $\begin{array}{l}\text { C. elegans Strain MT25692: ced-3(n3692) IV; } \\
\text { Itls } 44 \mathrm{~V} \text {; stls } 10026\end{array}$ & This paper & $\mathrm{N} / \mathrm{A}$ \\
\hline $\begin{array}{l}\text { C. elegans Strain MT25807: ced-3(n3692) IV; } \\
\text { nls861; isls } 17\end{array}$ & This paper & $\mathrm{N} / \mathrm{A}$ \\
\hline
\end{tabular}




\begin{tabular}{|c|c|c|}
\hline REAGENT OR RESOURCE & SOURCE & IDENTIFIER \\
\hline Escherichia coli: OP50 & Caenorhabditis Genetics Center & $\begin{array}{l}\text { WB Cat\#OP50, RRID:WB- } \\
\text { STRAIN:OP50 }\end{array}$ \\
\hline Escherichia coli: HT115 & Caenorhabditis Genetics Center & $\begin{array}{l}\text { WB Cat\#HT115, RRID:WB- } \\
\text { STRAIN:HT115 }\end{array}$ \\
\hline $\begin{array}{l}\text { Escherichia coli: HT115-pL4440 } \\
\text { (Control) }\end{array}$ & Timmons and Fire, (1998) & \\
\hline $\begin{array}{l}\text { Escherichia coli: HT115- } \\
\text { W03G6.1 (pig-1) }\end{array}$ & $\begin{array}{l}\text { Fraser et al. (2000), Source } \\
\text { BioScience }\end{array}$ & Cat\#3318_Cel_RNAi_complete \\
\hline $\begin{array}{l}\text { Escherichia coli: HT115- } \\
\text { C17G10.4 (cdc-14) }\end{array}$ & $\begin{array}{l}\text { Fraser et al. (2000), Source } \\
\text { BioScience }\end{array}$ & Cat\#3318_Cel_RNAi_complete \\
\hline $\begin{array}{l}\text { Escherichia coli: HT115- } \\
\text { K06A5.7 (cdc-25.1) }\end{array}$ & $\begin{array}{l}\text { Fraser et al. (2000), Source } \\
\text { BioScience }\end{array}$ & Cat\#3318_Cel_RNAi_complete \\
\hline $\begin{array}{l}\text { Escherichia coli: HT115- } \\
\text { F16B4.8 (cdc-25.2) }\end{array}$ & $\begin{array}{l}\text { Fraser et al. (2000), Source } \\
\text { BioScience }\end{array}$ & Cat\#3318_Cel_RNAi_complete \\
\hline $\begin{array}{l}\text { Escherichia coli: HT115- } \\
\text { ZK637.11 (cdc-25.3) }\end{array}$ & $\begin{array}{l}\text { Fraser et al. (2000), Source } \\
\text { BioScience }\end{array}$ & Cat\#3318_Cel_RNAi_complete \\
\hline $\begin{array}{l}\text { Escherichia coli: HT115- } \\
\text { R05H5.2 (cdc-25.4) }\end{array}$ & $\begin{array}{l}\text { Fraser et al. (2000), Source } \\
\text { BioScience }\end{array}$ & Cat\#3318_Cel_RNAi_complete \\
\hline $\begin{array}{l}\text { Escherichia coli: HT115- } \\
\text { T05G5.3 (cdk-1) }\end{array}$ & $\begin{array}{l}\text { Rual et al., (2004), Open } \\
\text { BioSystems }\end{array}$ & Cat\#RCE1182 \\
\hline $\begin{array}{l}\text { Escherichia coli: HT115- } \\
\text { B0495.2 (cdk-11.1) }\end{array}$ & $\begin{array}{l}\text { Fraser et al. (2000), Source } \\
\text { BioScience }\end{array}$ & Cat\#3318_Cel_RNAi_complete \\
\hline $\begin{array}{l}\text { Escherichia coli: HT115- } \\
\text { ZC504.3 (cdk-11.2) }\end{array}$ & $\begin{array}{l}\text { Fraser et al. (2000), Source } \\
\text { BioScience }\end{array}$ & Cat\#3318_Cel_RNAi_complete \\
\hline $\begin{array}{l}\text { Escherichia coli: HT115- } \\
\text { B0285.1 (cdk-12) }\end{array}$ & $\begin{array}{l}\text { Rual et al., (2004), Open } \\
\text { BioSystems }\end{array}$ & Cat\#RCE1182 \\
\hline $\begin{array}{l}\text { Escherichia coli: HT115- } \\
\text { K03E5.3 (cdk-2) }\end{array}$ & $\begin{array}{l}\text { Fraser et al. (2000), Source } \\
\text { BioScience }\end{array}$ & Cat\#3318_Cel_RNAi_complete \\
\hline $\begin{array}{l}\text { Escherichia coli: HT115- } \\
\text { F18H3.5 (cdk-4) }\end{array}$ & $\begin{array}{l}\text { Fraser et al. (2000), Source } \\
\text { BioScience }\end{array}$ & Cat\#3318_Cel_RNAi_complete \\
\hline $\begin{array}{l}\text { Escherichia coli: HT115- } \\
\text { T27E9.3 (cdk-5) }\end{array}$ & $\begin{array}{l}\text { Fraser et al. (2000), Source } \\
\text { BioScience }\end{array}$ & Cat\#3318_Cel_RNAi_complete \\
\hline $\begin{array}{l}\text { Escherichia coli: HT115- } \\
\text { Y39G10AL.3 (cdk-7) }\end{array}$ & $\begin{array}{l}\text { Rual et al., (2004), Open } \\
\text { BioSystems }\end{array}$ & Cat\#RCE1182 \\
\hline $\begin{array}{l}\text { Escherichia coli: HT115- } \\
\text { F39H11.3 (cdk-8) }\end{array}$ & $\begin{array}{l}\text { Fraser et al. (2000), Source } \\
\text { BioScience }\end{array}$ & Cat\#3318_Cel_RNAi_complete \\
\hline $\begin{array}{l}\text { Escherichia coli: HT115- } \\
\text { H25P06.2 (cdk-9) }\end{array}$ & $\begin{array}{l}\text { Fraser et al. (2000), Source } \\
\text { BioScience }\end{array}$ & Cat\#3318_Cel_RNAi_complete \\
\hline $\begin{array}{l}\text { Escherichia coli: HT115- } \\
\text { Y54E10A.15 (cdt-1) }\end{array}$ & $\begin{array}{l}\text { Rual et al., (2004), Open } \\
\text { BioSystems }\end{array}$ & Cat\#RCE1182 \\
\hline $\begin{array}{l}\text { Escherichia coli: HT115- } \\
\text { Y39H10A.7 (chk-1) }\end{array}$ & $\begin{array}{l}\text { Rual et al., (2004), Open } \\
\text { BioSystems }\end{array}$ & Cat\#RCE1182 \\
\hline $\begin{array}{l}\text { Escherichia coli: HT115- } \\
\text { F44B9.4 (cit-1.1) }\end{array}$ & Source BioScience & $\begin{array}{l}\text { Cat\#3317_Cel_RNAi_suppleme } \\
\text { nt_whole }\end{array}$ \\
\hline $\begin{array}{l}\text { Escherichia coli: HT115- } \\
\text { F44B9.3 (cit-1.2) }\end{array}$ & $\begin{array}{l}\text { Fraser et al. (2000), Source } \\
\text { BioScience }\end{array}$ & Cat\#3318_Cel_RNAi_complete \\
\hline $\begin{array}{l}\text { Escherichia coli: HT115- } \\
\text { T05A6.1 (cki-1) }\end{array}$ & $\begin{array}{l}\text { Fraser et al. (2000), Source } \\
\text { BioScience }\end{array}$ & Cat\#3318_Cel_RNAi_complete \\
\hline $\begin{array}{l}\text { Escherichia coli: HT115- } \\
\text { T05A6.2 (cki-2) }\end{array}$ & $\begin{array}{l}\text { Fraser et al. (2000), Source } \\
\text { BioScience }\end{array}$ & Cat\#3318_Cel_RNAi_complete \\
\hline $\begin{array}{l}\text { Escherichia coli: HT115- } \\
\text { C07H6.6 (clk-2) }\end{array}$ & Source BioScience & $\begin{array}{l}\text { Cat\#3317_Cel_RNAi_suppleme } \\
\text { nt_whole }\end{array}$ \\
\hline $\begin{array}{l}\text { Escherichia coli: HT115- } \\
\text { D2045.6 (cul-1) }\end{array}$ & $\begin{array}{l}\text { Fraser et al. (2000), Source } \\
\text { BioScience }\end{array}$ & Cat\#3318_Cel_RNAi_complete \\
\hline $\begin{array}{l}\text { Escherichia coli: HT115- } \\
\text { ZK520.4 (cul-2) }\end{array}$ & $\begin{array}{l}\text { Rual et al., (2004), Open } \\
\text { BioSystems }\end{array}$ & Cat\#RCE1182 \\
\hline
\end{tabular}




\begin{tabular}{|c|c|c|}
\hline $\begin{array}{l}\text { Escherichia coli: HT115- } \\
\text { Y108G3AL.1 (cul-3) }\end{array}$ & Source BioScience & $\begin{array}{l}\text { Cat\#3317_Cel_RNAi_suppleme } \\
\text { nt_whole }\end{array}$ \\
\hline $\begin{array}{l}\text { Escherichia coli: HT115- } \\
\text { F45E12.3 (cul-4) }\end{array}$ & $\begin{array}{l}\text { Fraser et al. (2000), Source } \\
\text { BioScience }\end{array}$ & Cat\#3318_Cel_RNAi_complete \\
\hline $\begin{array}{l}\text { Escherichia coli: HT115- } \\
\text { ZK507.6 (cya-1) }\end{array}$ & $\begin{array}{l}\text { Rual et al., (2004), Open } \\
\text { BioSystems }\end{array}$ & Cat\#RCE1182 \\
\hline $\begin{array}{l}\text { Escherichia coli: HT115- } \\
\text { ZC168.4 (cyb-1) }\end{array}$ & Source BioScience & $\begin{array}{l}\text { Cat\#3317_Cel_RNAi_suppleme } \\
\text { nt_whole }\end{array}$ \\
\hline $\begin{array}{l}\text { Escherichia coli: HT115- } \\
\text { Y43E12A.1 (cyb-2.1) }\end{array}$ & $\begin{array}{l}\text { Rual et al., (2004), Open } \\
\text { BioSystems }\end{array}$ & Cat\#RCE1182 \\
\hline $\begin{array}{l}\text { Escherichia coli: HT115- } \\
\text { H31G24.4 (cyb-2.2) }\end{array}$ & $\begin{array}{l}\text { Rual et al., (2004), Open } \\
\text { BioSystems }\end{array}$ & Cat\#RCE1182 \\
\hline $\begin{array}{l}\text { Escherichia coli: HT115- } \\
\text { T06E6.2 (cyb-3) }\end{array}$ & $\begin{array}{l}\text { Fraser et al. (2000), Source } \\
\text { BioScience }\end{array}$ & Cat\#3318_Cel_RNAi_complete \\
\hline $\begin{array}{l}\text { Escherichia coli: HT115- } \\
\text { H14E04.5 (cic-1) }\end{array}$ & Source BioScience & $\begin{array}{l}\text { Cat\#3317_Cel_RNAi_suppleme } \\
\text { nt_whole }\end{array}$ \\
\hline $\begin{array}{l}\text { Escherichia coli: HT115- } \\
\text { Y38F1A.5 (cyd-1) }\end{array}$ & $\begin{array}{l}\text { Fraser et al. (2000), Source } \\
\text { BioScience }\end{array}$ & Cat\#3318_Cel_RNAi_complete \\
\hline $\begin{array}{l}\text { Escherichia coli: HT115- } \\
\text { C37A2.4 (cye-1) }\end{array}$ & $\begin{array}{l}\text { Rual et al., (2004), Open } \\
\text { BioSystems }\end{array}$ & Cat\#RCE1182 \\
\hline $\begin{array}{l}\text { Escherichia coli: HT115- } \\
\text { Y49F6B.1 (cyh-1) }\end{array}$ & $\begin{array}{l}\text { Rual et al., (2004), Open } \\
\text { BioSystems }\end{array}$ & Cat\#RCE1182 \\
\hline $\begin{array}{l}\text { Escherichia coli: HT115- } \\
\text { C52E4.6 (cyl-1) }\end{array}$ & $\begin{array}{l}\text { Fraser et al. (2000), Source } \\
\text { BioScience }\end{array}$ & Cat\#3318_Cel_RNAi_complete \\
\hline $\begin{array}{l}\text { Escherichia coli: HT115- } \\
\text { ZK353.1 (cyy-1) }\end{array}$ & $\begin{array}{l}\text { Fraser et al. (2000), Source } \\
\text { BioScience }\end{array}$ & Cat\#3318_Cel_RNAi_complete \\
\hline $\begin{array}{l}\text { Escherichia coli: HT115- } \\
\text { T23G7.1 (dpl-1) }\end{array}$ & Source BioScience & $\begin{array}{l}\text { Cat\#3317_Cel_RNAi_suppleme } \\
\text { nt_whole }\end{array}$ \\
\hline $\begin{array}{l}\text { Escherichia coli: HT115- } \\
\text { Y102A5C.18 (efl-1) }\end{array}$ & $\begin{array}{l}\text { Fraser et al. (2000), Source } \\
\text { BioScience }\end{array}$ & Cat\#3318_Cel_RNAi_complete \\
\hline $\begin{array}{l}\text { Escherichia coli: HT115- } \\
\text { F10B5.6 (emb-27) }\end{array}$ & $\begin{array}{l}\text { Fraser et al. (2000), Source } \\
\text { BioScience }\end{array}$ & Cat\#3318_Cel_RNAi_complete \\
\hline $\begin{array}{l}\text { Escherichia coli: HT115- } \\
\text { F54C8.3 (emb-30) }\end{array}$ & $\begin{array}{l}\text { Fraser et al. (2000), Source } \\
\text { BioScience }\end{array}$ & Cat\#3318_Cel_RNAi_complete \\
\hline $\begin{array}{l}\text { Escherichia coli: HT115- } \\
\text { ZK1307.6 (fzr-1) }\end{array}$ & Source BioScience & $\begin{array}{l}\text { Cat\#3317_Cel_RNAi_suppleme } \\
\text { nt_whole }\end{array}$ \\
\hline $\begin{array}{l}\text { Escherichia coli: HT115- } \\
\text { ZK177.6 }(f z y-1)\end{array}$ & $\begin{array}{l}\text { Fraser et al. (2000), Source } \\
\text { BioScience }\end{array}$ & Cat\#3318_Cel_RNAi_complete \\
\hline $\begin{array}{l}\text { Escherichia coli: HT115- } \\
\text { F32A11.2 (hpr-17) }\end{array}$ & $\begin{array}{l}\text { Fraser et al. (2000), Source } \\
\text { BioScience }\end{array}$ & Cat\#3318_Cel_RNAi_complete \\
\hline $\begin{array}{l}\text { Escherichia coli: HT115- } \\
\text { H26D21.1 (hus-1) }\end{array}$ & $\begin{array}{l}\text { Fraser et al. (2000), Source } \\
\text { BioScience }\end{array}$ & Cat\#3318_Cel_RNAi_complete \\
\hline $\begin{array}{l}\text { Escherichia coli: HT115- } \\
\text { K10B2.1 (lin-23) }\end{array}$ & $\begin{array}{l}\text { Fraser et al. (2000), Source } \\
\text { BioScience }\end{array}$ & Cat\#3318_Cel_RNAi_complete \\
\hline $\begin{array}{l}\text { Escherichia coli: HT115- } \\
\text { C32F10.2 (lin-35) }\end{array}$ & $\begin{array}{l}\text { Fraser et al. (2000), Source } \\
\text { BioScience }\end{array}$ & Cat\#3318_Cel_RNAi_complete \\
\hline $\begin{array}{l}\text { Escherichia coli: HT115- } \\
\text { F44B9.6 (lin-36) }\end{array}$ & $\begin{array}{l}\text { Fraser et al. (2000), Source } \\
\text { BioScience }\end{array}$ & Cat\#3318_Cel_RNAi_complete \\
\hline $\begin{array}{l}\text { Escherichia coli: HT115- } \\
\text { ZK637.7 (lin-9) }\end{array}$ & $\begin{array}{l}\text { Fraser et al. (2000), Source } \\
\text { BioScience }\end{array}$ & Cat\#3318_Cel_RNAi_complete \\
\hline $\begin{array}{l}\text { Escherichia coli: HT115- } \\
\text { Y110A7A.17 (mat-1) }\end{array}$ & $\begin{array}{l}\text { Rual et al., (2004), Open } \\
\text { BioSystems }\end{array}$ & Cat\#RCE1182 \\
\hline $\begin{array}{l}\text { Escherichia coli: HT115- } \\
\text { F10C5.1 (mat-3) }\end{array}$ & $\begin{array}{l}\text { Rual et al., (2004), Open } \\
\text { BioSystems }\end{array}$ & Cat\#RCE1182 \\
\hline $\begin{array}{l}\text { Escherichia coli: HT115- } \\
\text { C50F4.11 (mdf-1) }\end{array}$ & $\begin{array}{l}\text { Rual et al., (2004), Open } \\
\text { BioSystems }\end{array}$ & Cat\#RCE1182 \\
\hline $\begin{array}{l}\text { Escherichia coli: HT115- } \\
\text { Y69A2AR.30 (mdf-2) }\end{array}$ & $\begin{array}{l}\text { Rual et al., (2004), Open } \\
\text { BioSystems }\end{array}$ & Cat\#RCE1182 \\
\hline
\end{tabular}




\begin{tabular}{|c|c|c|}
\hline $\begin{array}{l}\text { Escherichia coli: HT115- } \\
\text { Y41C4A.14 (mrt-2) }\end{array}$ & $\begin{array}{l}\text { Rual et al., (2004), Open } \\
\text { BioSystems }\end{array}$ & Cat\#RCE1182 \\
\hline $\begin{array}{l}\text { Escherichia coli: HT115- } \\
\text { T23G5.1 (rnr-1) }\end{array}$ & $\begin{array}{l}\text { Rual et al., (2004), Open } \\
\text { BioSystems }\end{array}$ & Cat\#RCE1182 \\
\hline $\begin{array}{l}\text { Escherichia coli: HT115- } \\
\text { ZC328.4 (san-1) }\end{array}$ & $\begin{array}{l}\text { Rual et al., (2004), Open } \\
\text { BioSystems }\end{array}$ & Cat\#RCE1182 \\
\hline $\begin{array}{l}\text { Escherichia coli: HT115- } \\
\text { F35H8.7 (wee-1.1) }\end{array}$ & $\begin{array}{l}\text { Rual et al., (2004), Open } \\
\text { BioSystems }\end{array}$ & Cat\#RCE1182 \\
\hline $\begin{array}{l}\text { Escherichia coli: HT115- } \\
\text { Y53C12A.1 (wee-1.3) }\end{array}$ & $\begin{array}{l}\text { Rual et al., (2004), Open } \\
\text { BioSystems }\end{array}$ & Cat\#RCE1182 \\
\hline $\begin{array}{l}\text { Escherichia coli: HT115- R53.6 } \\
\text { (psf-1) }\end{array}$ & $\begin{array}{l}\text { Rual et al., (2004), Open } \\
\text { BioSystems }\end{array}$ & Cat\#RCE1182 \\
\hline $\begin{array}{l}\text { Escherichia coli: HT115- } \\
\text { F31C3.5 (psf-2) }\end{array}$ & $\begin{array}{l}\text { Rual et al., (2004), Open } \\
\text { BioSystems }\end{array}$ & Cat\#RCE1182 \\
\hline $\begin{array}{l}\text { Escherichia coli: HT115- } \\
\text { Y65B4BR.8 (psf-3) }\end{array}$ & $\begin{array}{l}\text { Rual et al., (2004), Open } \\
\text { BioSystems }\end{array}$ & Cat\#RCE1182 \\
\hline $\begin{array}{l}\text { Escherichia coli: HT115- } \\
\text { Y59A8A.1 (csn-1) }\end{array}$ & $\begin{array}{l}\text { Rual et al., (2004), Open } \\
\text { BioSystems }\end{array}$ & Cat\#RCE1182 \\
\hline $\begin{array}{l}\text { Escherichia coli: HT115- } \\
\text { Y55F3AM.15 (csn-4) }\end{array}$ & $\begin{array}{l}\text { Rual et al., (2004), Open } \\
\text { BioSystems }\end{array}$ & Cat\#RCE1182 \\
\hline $\begin{array}{l}\text { Escherichia coli: HT115- } \\
\text { B0547.1 (csn-5) }\end{array}$ & $\begin{array}{l}\text { Rual et al., (2004), Open } \\
\text { BioSystems }\end{array}$ & Cat\#RCE1182 \\
\hline $\begin{array}{l}\text { Escherichia coli: HT115- } \\
\text { Y39A1A.23 (hpr-9) }\end{array}$ & Source BioScience & $\begin{array}{l}\text { Cat\#3317_Cel_RNAi_suppleme } \\
\text { nt_whole }\end{array}$ \\
\hline $\begin{array}{l}\text { Escherichia coli: HT115- } \\
\text { Y75B8A.22 (tim-1) }\end{array}$ & Source BioScience & $\begin{array}{l}\text { Cat\#3317_Cel_RNAi_suppleme } \\
\text { nt_whole }\end{array}$ \\
\hline $\begin{array}{l}\text { Escherichia coli: HT115- } \\
\text { F23C8.9 (tipn-1) }\end{array}$ & $\begin{array}{l}\text { Fraser et al. (2000), Source } \\
\text { BioScience }\end{array}$ & Cat\#3318_Cel_RNAi_complete \\
\hline $\begin{array}{l}\text { Escherichia coli: HT115- } \\
\text { F37D6.1 (mus-101) }\end{array}$ & $\begin{array}{l}\text { Fraser et al. (2000), Source } \\
\text { BioScience }\end{array}$ & Cat\#3318_Cel_RNAi_complete \\
\hline $\begin{array}{l}\text { Escherichia coli: HT115- } \\
\text { F25H5.5 (clsp-1) }\end{array}$ & $\begin{array}{l}\text { Fraser et al. (2000), Source } \\
\text { BioScience }\end{array}$ & Cat\#3318_Cel_RNAi_complete \\
\hline $\begin{array}{l}\text { Escherichia coli: HT115- } \\
\text { F18A1.5 (rpa-1) }\end{array}$ & $\begin{array}{l}\text { Fraser et al. (2000), Source } \\
\text { BioScience }\end{array}$ & Cat\#3318_Cel_RNAi_complete \\
\hline $\begin{array}{l}\text { Escherichia coli: HT115- } \\
\text { T06E4.3 (atl-1) }\end{array}$ & This paper & N/A \\
\hline $\begin{array}{l}\text { Escherichia coli: HT115- } \\
\text { W10C6.1 (mat-2) }\end{array}$ & This paper & N/A \\
\hline $\begin{array}{l}\text { Escherichia coli: HT115- } \\
\text { ZK662.4 (lin-15B) }\end{array}$ & This paper & N/A \\
\hline $\begin{array}{l}\text { C. elegans ORFeome RNAi } \\
\text { Library v1.1 }\end{array}$ & $\begin{array}{l}\text { Rual et al., (2004), Open } \\
\text { BioSystems }\end{array}$ & Cat\#RCE1182 \\
\hline
\end{tabular}




\section{Materials and Methods}

\section{$775 \quad$ Plasmids}

776 L4054 was a gift from Andrew Fire (Addgene plasmid \# 1632;

777 http://n2t.net/addgene:1632 ; RRID:Addgene_1632). pDD111 - $P_{\text {egl- }}$

778 1::mCherry::PH::unc-54 3'UTR was generated with the following steps: i) $6.8 \mathrm{~Kb}$

779 of the egl-1 promoter was amplified from genomic DNA with Phusion DNA

780 polymerase using the primers DPD660 and DPD661; ii) the amplicon was

781 digested with Pstl and Sacl (New England Biolabs) and ligated into pPD122.56,

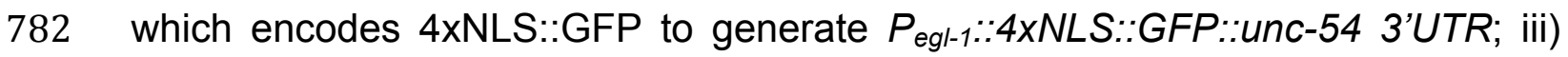

783 mCherry-PH (ㄹeckstrin Homology) sequence was amplified from pAA173 using

784 DPD647 and DPD648 and digested with EcoRI and Agel (New England Biolabs)

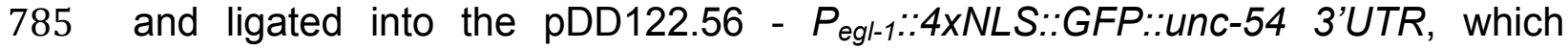

786 generated the plasmid pDD122.56 - Pegl-1::4xNLS::mCherry::PH::unc-54 3'UTR;

787 iv) the $4 \times$ NLS sequence was removed with the primers DPD695 and DPD696

788 using QuikChange Site-Directed Mutagenesis (Agilent) to generate pDD111 -

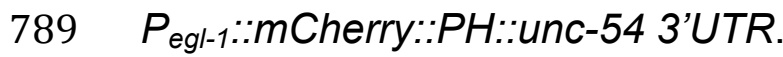

790 RNAi clones were constructed for atl-1, mat-2 and lin-15B. Genomic regions of

791 about $1 \mathrm{~kb}$ were amplified from wild-type genomic lysates using Q5 Hot Start

792 high-fidelity polymerase (New England Biolabs) with the following primers:

793 atl-1

794 RD105 TCGAATTCCTGCAGCTCCTCGAACCCATCATCCCT

795 RD106 TGACGCGTGGATCCCATGAAGCTGCGTGGTTGTTG

796 mat-2 
797 RD103 TCGAATTCCTGCAGCCTGGAACTCATCCCATACGC

798 RD104 TGACGCGTGGATCCCCATTGGAACCTCCAGATGCT

799 lin-15B

800 RD101 TCGAATTCCTGCAGCGCTGACACAATTGCGAACAT

801 RD102 TGACGCGTGGATCCCCGTGTGCATAAAGACCAAGG

802 These inserts were cloned into the pL4440 vector linearized with Xmal (New

803 England Biolabs) using the In-Fusion HD cloning kit (TaKaRa) according to

804 manufacturers instructions. The cloned vector was then transformed into

805 competent HT115 bacterial cells. Correct RNAi clones were identified by Sanger

806 sequencing. Geneious 10.2.6 (Biomatters, Inc.) was used to guide all plasmid

807 design and construction.

808 Contact for Reagent and Resource Sharing

809 Further information and resource sharing requests should be directed to and will

810 be fulfilled by the lead contact, H. Robert Horvitz (horvitz@mit.edu).

811 Strains, transgenes and mutations

812

813 C. elegans hermaphrodite strains were maintained on Nematode Growth Medium

814 (NGM) plates containing $3 \mathrm{~g} / \mathrm{L} \mathrm{NaCl}, 2.5 \mathrm{~g} / \mathrm{L}$ peptone and $17 \mathrm{~g} / \mathrm{L}$ agar 815 supplemented with $1 \mathrm{mM} \mathrm{CaCl}, 1 \mathrm{mM} \mathrm{MgSO}_{4}, 1 \mathrm{mM} \mathrm{KPO}_{4}$ and $5 \mathrm{mg} / \mathrm{L}$

816 Cholesterol with E. coli OP50 as a source of food (Brenner, 1974). All strains

817 were derived from Bristol N2 and are listed in Table S2. ced-3(If) refers to the

$818 n 3692$ deletion allele of ced-3 (Denning et al., 2012). C. elegans strains carrying

819 the transgenes $n / s 861$ and is $/ s 17$ were maintained at $25^{\circ} \mathrm{C}$. All other strains were

820 maintained at $22^{\circ} \mathrm{C}$. The transgenes and mutations used are listed below: 
821 LGI: nIs433[P pgp-12::4xNLS::GFP::unc-54 3’UTR; p76-16B(unc-76(+))]

822 LGII: heSi192[P eft-3::tDHB::eGFP::tbb-2 3’UTR + Cbr-unc119(+)]

823 LGIII: unc-119(ed3)

824 LGIV: ced-3(n3692, n717)

825 LGV: unc-76(e911), It/s44[P pie-1::mCherry::PH(PLC1delta1) + unc-119(+)]

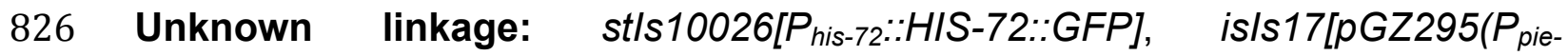

827 1::GFP::pcn-1(W03D2.4)), pDP\#MM051 (unc-119(+))], nls861[pDD111(P egl-

828 1::mCherry::PH::unc-54 3'UTR)], n/s632[pDD111(P egl-1::mCherry::PH::unc-54

829 3'UTR), pML902 (dlg-1::GFP),p76-16B(unc-76(+))]

830 Extrachromosomal array: $n E x 2188\left[p D D 111\left(P_{\text {egl- } 1:: m C h e r r y:: P H:: u n c-54}\right.\right.$

831 3'UTR), pML902 (dlg-1::GFP), unc-76(+)]

832 nls632 and n/s861 express membrane-localized mCherry from the egl-1

833 promoter, which facilitated the identification of ABplpappap (an egl-1 expressing

834 cell). $n / s 632$ does not express $d / g-1:: G F P$, presumably as a result of partial

835 transgene silencing (Hsieh et al. 1999; Grishok et al. 2005; Fischer et al. 2013).

836 st/s10026 (Boeck et al., 2011) ubiquitously expresses a GFP-tagged histone

837 HIS-72 from its endogenous promoter, which produces fluorescence in the nuclei

838 of all cells and facilitates in providing the context in which extrusion events are

839 observed.

\section{Germline transformation}

841 Transgenic lines were generated using the standard germline transformation

842 procedure (Mello et al., 1991). Extrachromosomal array transgene $n E x 2188$ was

843 generated by injecting pML902 at $3 \mathrm{ng} / \mu \mathrm{L}$, pDD111 at $40 \mathrm{ng} / \mu \mathrm{L}, \mathrm{p} 76-16 \mathrm{~B}$ (unc- 
$84476(+))$ at $60 \mathrm{ng} / \mathrm{ul}$ and $1 \mathrm{~Kb}$ Plus DNA ladder (Thermo Fischer Scientific) at $50 \mathrm{ng} /$

$845 \mu$ into ced-3(n717) IV; unc-76(e911) $V$ double mutant animals. nls632 was

846 generated by gamma-ray irradiation (4,800 rads) of $n E x 2188$-carrying L4 animals

847 and was identified by the $100 \%$ transmission of the transgene from transformed

848 parent to progeny. $n / s 861$ was a spontaneous integration in a germline cell of an

849 animal injected with pDD111 at $10 \mathrm{ng} / \mu \mathrm{L}$ and $1 \mathrm{~kb}$ DNA ladder at $90 \mathrm{ng} / \mu \mathrm{L}$, and

850 was identified by the $100 \%$ transmission of the transgene from transformed

851 parent to progeny.

\section{RNAi treatments and genome-wide RNAi screen}

853 Previously described feeding RNAi constructs and reagents were used to

854 perform RNAi feeding experiments (Fraser et al., 2000; Rual et al., 2004). Briefly,

855 HT115 Escherichia coli bacteria carrying RNAi clones in the pL4440 vector were

856 grown for at least $12 \mathrm{~h}$ in Luria broth (LB) liquid media with $75 \mathrm{mg} / \mathrm{L}$ ampicillin at

$85737^{\circ} \mathrm{C}$. These cultures were seeded onto $6 \mathrm{~cm}$ Petri plates with Nematode Growth

858 Medium (NGM) containing $1 \mathrm{mM}$ isopropyl- $\beta$-D-thiogalactopyranoside (IPTG)

859 (Amresco) and $75 \mathrm{mg} / \mathrm{L}$ ampicillin and incubated for $24 \mathrm{~h}$ at $22^{\circ} \mathrm{C}$. For imaging

860 experiments using confocal microscopy, 10 L4 animals were added to each RNAi

861 plate and imaging of progeny embryos was performed on the next day as

862 described in Microscopy below. For excretory cell counts, five L4 animals were

863 added to each RNAi plate and L3-L4 progeny were scored for number of

864 excretory cells, as described in Excretory cell count below. In case a bacterial

865 clone targeting a certain gene was not available in previously constructed 
866 libraries (Kamath et al., 2003; Rual et al., 2004), we generated our own RNAi

867 clone as described in Molecular biology above.

868 The ORFeome RNAi library was used to conduct a genome-wide RNAi

869 screen (Rual et al., 2004). For each day of the RNAi screen, all bacterial colonies

870 from two 96 -well plates were cultured for at least $12 \mathrm{~h}$ at $37^{\circ} \mathrm{C}$ in LB with $75 \mathrm{mg} / \mathrm{L}$

871 ampicillin. These cultures were then pre-incubated with $1 \mathrm{mM}$ IPTG (Amresco)

872 for $1 \mathrm{~h}$ to maximize induction of dsRNA production. 24-well plates with each well

873 containing $2 \mathrm{~mL}$ NGM medium with $1 \mathrm{mM}$ IPTG (Amresco) and $75 \mathrm{mg} / \mathrm{L}$

874 ampicillin were prepared in advance and stored at $4^{\circ} \mathrm{C}$ until needed; they were

875 brought to room temperature a few hours before seeding. Each bacterial colony

876 culture was then seeded onto an individual well of a 24-well plate and incubated

877 for $24 \mathrm{~h}$ at $20^{\circ} \mathrm{C}$. Three L4 animals were picked into a $10 \mu$ drop of M9 medium,

878 which facilitated their transfer into a well using a pipette. The progeny of these 3

879 animals were screened 3 days later. Each set of RNAi clones screened also

880 included a pig-1 RNAi positive control and an empty pL4440 vector negative

881 control. The scorer was blinded to the identity of the RNAi clones. Excretory cell

882 counts were performed as described in Excretory cell counts below. Sanger

883 sequencing was used to confirm the identity of RNAi clones that reproducibly

884 generated a Tex phenotype for more than $10 \%$ of the animals scored.

\section{Microscopy}

886 All RNAi screens scoring excretory cells were performed using a Nikon SMZ18

887 fluorescent dissecting microscope. DIC and epifluorescence images were 
888 obtained using a $63 x$ objective lens (Zeiss) on an Axiolmager Z2 (Zeiss) 889 compound microscope and Zen Blue software (Zeiss).

890 For confocal microscopy, embryos staged at the 200-300-cell stage were 891 picked and mounted onto a glass slide (Corning) with a freshly prepared $2 \%$ 892 agarose pad. Embryos with ventral surfaces facing the objective were selected 893 for imaging. Confocal images were obtained using a $63 x$ objective lens (Zeiss) on 894 a Zeiss LSM800 confocal microscope.

895 For observing extrusion (or absence of extrusion), we focused particularly 896 on the cell ABplpappap, the identification of which is facilitated by its central 897 position on the ventral surface (Sulston et al., 1983). The fluorescent transgene 898 nls861[Pegl-1::mCherry::PH] or nls632[Pegl-1::mCherry::PH; dlg-1::GFP], which 899 express the Pleckstrin homology domain of PLC- $\delta$ fused to mCherry from the 900 promoter of egl-1, was used to label the membrane of the ABplpappap cell, an 901 egl-1 expressing cell (Denning et al., 2012), to further facilitate cell identification. 902 Another fluorescent transgene st/s10026[his-72::GFP], which expresses GFP903 tagged HIS-72 histone protein, was used to label the nuclei of all cells to help 904 define ABplpappap's location within the embryo. Time-lapse confocal microscopy 905 was used to monitor the location of ABplpappap in embryos, keeping the cell in 906 view by refocusing on it every $30 \mathrm{sec}$. Confocal imaging during a period of about 90750 min during which ventral enclosure (migration and meeting of hypodermal 908 cells on the ventral surface of the embryo) occurs was sufficient to determine 909 whether ABplpappap did or did not undergo extrusion. 
$910 \quad$ For determining whether ABplpappap and other cells that are extruded

911 entered the cell cycle, the transgene heSi192[Peft-3::tDHB::eGFP::tbb-2 3'UTR]

912 was used to express a codon-optimized (for C. elegans) C-terminal fragment of

913 Human DNA Helicase B, which translocates from the nucleus to the cytoplasm in

914 response to the activity of the cell cycle CDKs 1 and 2 (van Rijnberk et al., 2017).

$915 n / s 861$ was used to label the membrane of ABplpappap with mCherry to facilitate 916 cell identification.

917 For determining the cell cycle phase of ABplpappap and other extruded 918 cells, is/s17[Ppie-1::GFP::PCN-1] was used to express GFP-tagged PCN-1

919 protein, which produces a phase-specific fluorescence intensity and localization 920 pattern. $n / s 861$ was used to label the membrane of ABplpappap with mCherry to 921 facilitate cell identification.

922 Images were processed with ImageJ software (NIH), Photoshop CC 2019

923 (Adobe) and Illustrator CC 2019 (Adobe) software. The Time Stamper function in

924 the Stowers ImageJ plugin was used to mark elapsed time on time-lapse videos.

\section{Excretory cell counts}

926 Excretory cell counts were performed using a dissecting microscope equipped 927 with fluorescence at a total magnification of $270 x$. For the genome-wide RNAi 928 screen, roughly 50 animals were examined in each well of a 24-well plate and 929 any well with more than 5 animals with two excretory cells was marked for 930 confirmatory testing. Excretory cell counts in confirmatory RNAi experiments, 931 candidate RNAi experiments and experiments with genetic mutants were 932 conducted using $6 \mathrm{~cm}$ Petri plates with appropriate media. Animals were first 
933 immobilized by keeping the Petri plates on ice for $30 \mathrm{~min}$. At least 100 animals at

934 the L3-L4 larval stage were scored for each genotype or RNAi experiment unless

935 there was extensive lethality or a growth defect, in which case a lower number or

936 earlier-stage animals, respectively, were scored. A cell was scored as an

937 excretory cell if it was located in the anterior half of the animal and its nucleus

938 had strong GFP expression.

939 tDHB-GFP fluorescence intensity quantification

940 The ABplpappap nuclear boundary, cell membrane boundary and the tDHB-GFP

941 fluorescence signal were determined from DIC, mCherry and GFP channels,

942 respectively, of confocal images of RNAi treated ced-3(If) embryos expressing

943 the transgenes heSi192 and $n / s 861$. Mean tDHB-GFP fluorescence intensities

944 inside the nuclear region, entire cell and background were quantified using Fiji

945 software. Mean cytoplasmic tDHB-GFP fluorescence intensity was calculated by

946 the following formula

$$
I_{\text {cytoplasm }}=\frac{\left(I_{\text {cell }} * \text { cell area }\right)-\left(I_{\text {nucleus }} * \text { nucleus area }\right)}{\text { cell area }- \text { nucleus area }}
$$

$947 I_{\text {cytoplasm, }} I_{\text {cell }}$ and $I_{\text {nucleus }}$ denote the mean tDHB fluorescence intensity in the 948 cytoplasm, cell and nucleus, respectively. The ratio of nuclear-to-cytoplasmic

949 tDHB fluorescence intensity in Figure $3 \mathrm{H}$ was adjusted for background

950 fluorescence (measured from a random area outside the embryo boundaries),

951 i.e., the background fluorescence intensity was subtracted from both nuclear and

952 cytoplasmic fluorescence intensity values before calculating the ratios.

\section{Calculation of cell size}


954 Confocal micrographs were obtained for multiple focal planes starting at the

955 ventral surface and ending at the dorsal surface of the embryo, with each plane

956 separated by a distance of $0.37 \mu \mathrm{m}$. The greatest area occupied by a cell in any

957 plane was designated the "maximum area" of a cell.

\section{Cell culture}

959 MDCK and MDCK-Fucci (Streichan et al., 2014) cells were cultured in DMEM

960 supplemented with $10 \%$ fetal bovine serum and $1 \%$ penicillin/streptomycin in a

961 humidified incubator at $37^{\circ} \mathrm{C}$ with $5 \% \mathrm{CO}_{2}$.

\section{Chemicals}

$9632 \mathrm{mM} \mathrm{HU}$ (Millipore Sigma, Cat\#H8627) was prepared in culture medium prior to

964 each experiment.

\section{Mammalian cell imaging}

966 These assays were performed using 6-well plastic plates. 20,000 MDCK cells

967 were seeded in each well and grown to confluence for $72 \mathrm{~h}$. The day of the

968 experiment, cells were washed twice with PBS and treated with fresh medium or

$9692 \mathrm{mM} \mathrm{HU}$ in medium. After equilibration, plates were imaged at 15-min intervals

970 for up to $24 \mathrm{~h}$, using an Evos M7000 imaging system equipped with a humidified

971 onstage incubator $\left(37^{\circ} \mathrm{C}, 5 \% \mathrm{CO}_{2}\right)$. Several positions per well were imaged in the

972 phase contrast and green and red fluorescence channels available in this 973 system.

\section{Mammalian cell extrusion quantification}

975 In time-lapse phase contrast images, extruding cells are easily identifiable as 976 bright, white, rounded spots emerging from the epithelial plane. We counted the 
977 number of cells with these features for each condition using the Cell Counter

978 plugin of Fiji (Schindelin et al., 2012). Extrusions are reported as number of

979 extruding cells/h for comparison between experiments of different duration.

\section{Mammalian cell cycle phase determination}

981 The Fucci system differentially labels the nuclei of cells in G1 (red) and S/G2/M

982 (green) (Sakaue-Sawano et al., 2008). Images of MDCK-Fucci cells with HU or

983 control treatment were obtained in the phase contrast, red and green

984 fluorescence channels as per Mammalian cell imaging above. For each position,

985 a multi-channel stack was built using Fiji (Schindelin et al., 2012). After

986 identifying an extruded cell in the phase contrast channel, the cell cycle phase

987 was determined using the fluorescence channels.

988 Mammalian re-seeding experiments

989 At the end of an imaging experiment, supernatants were collected and 990 centrifuged (1200 rpm, $5 \mathrm{~min}$, room temperature). Pellets were re-suspended in $99150 \mu \mathrm{L}$ of PBS, and $10 \mu \mathrm{L}$ of the suspension was used for cell counting with 992 Trypan blue in a Neubauer chamber, allowing us to simultaneously calculate the 993 number of cells being re-seeded and the fraction of cells that was apoptotic.

994 The remaining cells were seeded with $1 \mathrm{~mL}$ of fresh medium in a 24-well plate 995 and grown in the cell culture incubator. Pictures were taken at $2 \mathrm{~h}$ and $24 \mathrm{~h}$ for 996 cell counting.

\section{Statistical analysis}

998 For calculation of statistical significance for ratios, the ratios were first 999 transformed to logarithm values. Ordinary one-way ANOVA was performed to 
1000 determine statistical significance of the ratios with the assumption that logarithm

1001 of ratios produced a normal distribution of values. The maximum area of

1002 ABplpappap was also assumed to have normal distribution under different RNAi

1003 conditions and ordinary one-way ANOVA was used to determine statistical

1004 significance. Normal distributions with unequal variances were assumed for rates

1005 of extrusion under HU and vehicle treatments, and Welch's two-tailed t-test was

1006 performed to determine statistical significance. No assumptions were made

1007 about the distributions of the rates of apoptosis under $\mathrm{HU}$ and vehicle treatments,

1008 and hence the Mann-Whitney test was used to determine statistical significance.

1009 No assumptions were made about the distribution of fraction of extruded cells in

1010 different phases of the cell cycle after HU and vehicle treatments, and the

1011 Kruskal-Wallis test was used to determine statistical significance. Normal

1012 distribution was assumed for numbers of cells reseeded in fresh media after pre-

1013 treatment in different conditions, and ordinary one-way ANOVA was used to

1014 determine statistical significance. All statistical analysis was performed using

1015 Prism 7 (GraphPad Software). 
1016

1017

1018

1019

1020

1021

1022

1023

1024

1025

1026

1027

1028

1029

1030

1031

1032

1033

1034

1035

1036

1037

1038

1039

1040

1041

1042

1043

1044

1045

1046

1047

1048

1049

1050

1051

1052

1053

1054

1055

1056

1057

1058

1059

1060

1061

\section{References}

Andrade, D., and Rosenblatt, J. (2011). Apoptotic regulation of epithelial cellular extrusion. Apoptosis. 16, 491-501.

Anton, K.A., Kajita, M., Narumi, R., Fujita, Y., and Tada, M. (2018). Srctransformed cells hijack mitosis to extrude from the epithelium. Nat. Commun. 9, 4695.

Bianchi, V., Zantedeschi, A., and Levis, A.G. (1983). The scintillometric evaluation of DNA repair synthesis can be distorted by changes of thymidine pool radioactivity. Chem. Biol. Interact. 43,17-31.

Bloom, L., and Horvitz, H.R. (1997). The Caenorhabditis elegans gene unc-76 and its human homologs define a new gene family involved in axonal outgrowth and fasciculation. Proc. Natl. Acad. Sci. U. S. A. 94, 3414-3419.

Boeck, M.E., Boyle, T., Bao, Z., Murray, J., Mericle, B., and Waterston, R. (2011). Specific roles for the GATA transcription factors end-1 and end-3 during C. elegans E-lineage development. Dev. Biol. 358, 345-355.

Bowman, E.A., Bowman, C.R., Ahn, J.H., and Kelly, W.G. (2013). Phosphorylation of RNA polymerase II is independent of P-TEFb in the $C$. elegans germline. Development. 140, 3703-3713.

Brauchle, M., Baumer, K., and Gönczy, P. (2003). Differential activation of the DNA replication checkpoint contributes to asynchrony of cell division in $C$. elegans embryos. Curr Biol. 13, 819-827.

Brenner, S. (1974). The genetics of Caenorhabditis elegans. Genetics. 77, 71-94.

Carroll, T.D., Newton, I.P., Chen, Y., Blow, J.J., and Näthke, I. (2018). Lgr5+ intestinal stem cells reside in an unlicensed G1 phase. J. Cell Biol. 217, 1667-1685

Chisholm, A.D., and Hardin, J. (2005). Epidermal morphogenesis. WormBook. 1, $1-22$.

Cordes, S., Frank, C.A., and Garriga, G. (2006). The C. elegans MELK ortholog PIG-1 regulates cell size asymmetry and daughter cell fate in asymmetric neuroblast divisions. Development 133, 2747-2756.

De Goeij, J.M., De Kluijver, A., Van Duyl, F.C., Vacelet, J., Wijffels, R.H., De Goeij, A.F.R.M., Cleutjens, J.P.M., and Schutte, B. (2009). Cell kinetics of the marine sponge Halisarca caerulea reveal rapid cell turnover and shedding. J. Exp. Biol. 212, 3892-3900. 
1062

1063

1064

1065

1066

1067

1068

1069

1070

1071

1072

1073

1074

1075

1076

1077

1078

1079

1080

1081

1082

1083

1084

1085

1086

1087

1088

1089

1090

1091

1092

1093

1094

1095

1096

1097

1098

1099

1100

1101

1102

1103

1104

1105

1106

1107
Denning, D.P., Hatch, V., and Horvitz, H.R. (2012). Programmed elimination of cells by caspase-independent cell extrusion in C. elegans. Nature 488, 226-230.

Eisenhoffer, G.T., Loftus, P.D., Yoshigi, M., Otsuna, H., Chien, C.B., Morcos, P.A., and Rosenblatt, J. (2012). Crowding induces live cell extrusion to maintain homeostatic cell numbers in epithelia. Nature $484,546-549$.

Fay, D.S., and Han, M. (2000). Mutations in cye-1, a Caenorhabditis elegans Cyclin E homolog, reveal coordination between cell-cycle control and vulval development. Development. 127, 4049-4060.

Fischer, S.E.J., Pan, Q., Breen, P.C., Qi, Y., Shi, Z., Zhang, C., and Ruvkun, G. (2013). Multiple small RNA pathways regulate the silencing of repeated and foreign genes in C. elegans. Genes Dev. 27, 2678-2695.

Fraser, A.G., Kamath, R.S., Zipperlen, P., Martinez-Campos, M., Sohrmann, M., and Ahringer, J. (2000). Functional genomic analysis of C. elegans chromosome I by systematic RNA interference. Nature. 408, 325-330.

Fuchs, Y., and Steller, H. (2011). Programmed cell death in animal development and disease. Cell. 147, 742-758.

Gaillard, H., García-Muse, T., and Aguilera, A. (2015). Replication stress and cancer. Nat. Rev. Cancer 15, 276-289.

Grieve, A.G., and Rabouille, C. (2014). Extracellular cleavage of E-cadherin promotes epithelial cell extrusion. J. Cell Sci. 127, 3331-3346.

Grishok, A., Sinskey, J.L., and Sharp, P.A. (2005). Transcriptional silencing of a transgene by RNAi in the soma of C. elegans. Genes Dev. 19,683-696.

Gu, Y., and Rosenblatt, J. (2012). New emerging roles for epithelial cell extrusion. Curr. Opin. Cell Biol. 24, 865-870.

Gu, Y., Shea, J., Slattum, G., Firpo, M.A., Alexander, M., Golubovskaya, V.M., and Rosenblatt, J. (2015). Defective apical extrusion signaling contributes to aggressive tumor hallmarks. Elife. 4, e04069.

Gudipaty, S.A., and Rosenblatt, J. (2017). Epithelial cell extrusion: Pathways and pathologies. Semin. Cell Dev. Biol. 67, 132-140.

Gudipaty, S.A., Lindblom, J., Loftus, P.D., Redd, M.J., Edes, K., Davey, C.F., Krishnegowda, V., and Rosenblatt, J. (2017). Mechanical stretch triggers rapid epithelial cell division through Piezo1. Nature. 543, 118-121. 
1108

1109

1110

1111

1112

1113

1114

1115

1116

1117

1118

1119

1120

1121

1122

1123

1124

1125

1126

1127

1128

1129

1130

1131

1132

1133

1134

1135

1136

1137

1138

1139

1140

1141

1142

1143

1144

1145

1146

1147

1148

1149

1150

1151

1152

1153

Günther, J., and Seyfert, H.M. (2018). The first line of defence: insights into mechanisms and relevance of phagocytosis in epithelial cells. Semin. Immunopathol. 40, 555-565.

Hogan, C., Dupré-Crochet, S., Norman, M., Kajita, M., Zimmermann, C., Pelling, A.E., Piddini, E., Baena-López, L.A., Vincent, J.P., Itoh, Y., Hosoya, H., Pichaud, F., and Fujita, Y. (2009). Characterization of the interface between normal and transformed epithelial cells. Nat. Cell Biol. 11,460467.

Hsieh, J., Liu, J., Kostas, S.A., Chang, C., Sternberg, P.W., and Fire, A. (1999). The RING finger/B-box factor TAM-1 and a retinoblastoma-like protein LIN-35 modulate context-dependent gene silencing in Caenorhabditis elegans. Genes Dev. 13, 2958-2970.

Jin, J., Shirogane, T., Xu, L., Nalepa, G., Qin, J., Elledge, S.J., and Harper, J.W. (2003). SCF $\beta$-TRCP links Chk1 signaling to degradation of the Cdc25A protein phosphatase. Genes Dev. 17, 3062-3074.

Jones, M.C., Askari, J.A., Humphries, J.D., and Humphries, M.J. (2018). Cell adhesion is regulated by CDK1 during the cell cycle. J. Cell Biol. 217, 3203-3218.

Kachur, T.M., Audhya, A., and Pilgrim, D.B. (2008). UNC-45 is required for NMY2 contractile function in early embryonic polarity establishment and germline cellularization in C. elegans. Dev. Biol. 314, 287-299.

Kajita, M., Hogan, C., Harris, A.R., Dupre-Crochet, S., Itasaki, N., Kawakami, K., Charras, G., Tada, M., and Fujita, Y. (2010). Interaction with surrounding normal epithelial cells influences signalling pathways and behaviour of Src-transformed cells. J. Cell Sci. 123, 171-180.

Kajita, M., and Fujita, Y. (2015). EDAC: Epithelial defence against cancer - Cell competition between normal and transformed epithelial cells in mammals. J. Biochem. 158, 15-23.

Kamath, R.S., Fraser, A.G., Dong, Y., Poulin, G., Durbin, R., Gotta, M., Kanapin, A., Le Bot, N., Moreno, S., Sohrmann, M., Welchman, D.P., Zipperlen, P., and Ahringer, J. (2003). Systematic functional analysis of the Caenorhabditis elegans genome using RNAi. Nature. 421, 231-237.

Kipreos, E.T., Gohel, S.P., and Hedgecock, E.M. (2000). The C. elegans Fbox/WD-repeat protein LIN-23 functions to limit cell division during development. Development. 127, 5071-5082. 
1154

1155

1156

1157

1158

1159

1160

1161

1162

1163

1164

1165

1166

1167

1168

1169

1170

1171

1172

1173

1174

1175

1176

1177

1178

1179

1180

1181

1182

1183

1184

1185

1186

1187

1188

1189

1190

1191

1192

1193

1194

1195

1196

1197

Kocgozlu, L., Saw, T.B., Le, A.P., Yow, I., Shagirov, M., Wong, E., Mège, R.M., Lim, C.T., Toyama, Y., and Ladoux, B. (2016). Epithelial cell packing induces distinct modes of cell extrusions. Curr. Biol. 26, 2942-2950.

Kocsisova, Z., Kornfeld, K., and Schedl, T. (2018). Cell cycle accumulation of the proliferating cell nuclear antigen $\mathrm{PCN}-1$ transitions from continuous in the adult germline to intermittent in the early embryo of $C$. elegans. BMC Dev. Biol. 18, 12.

Krawchuk, D., Anani, S., Honma-Yamanaka, N., Polito, S., Shafik, M., and Yamanaka, Y. (2015). Loss of LKB1 leads to impaired epithelial integrity and cell extrusion in the early mouse embryo. J. Cell Sci. 128, 1011-1022.

Kreutzer, M.A., Richards, J.P., De Silva-Udawatta, M.N., Temenak, J.J., Knoblich, J.A., Lehner, C.F., and Bennett, K.L. (1995). Caenorhabditis elegans cyclin A- and B-type genes: A cyclin A multigene family, an ancestral cyclin B3 and differential germline expression. J. Cell Sci. 108, 2415-2424.

Lee, Y.U., Son, M., Kim, J., Shim, Y.H., and Kawasaki, I. (2016). CDC-25.2, a C. elegans ortholog of cdc25, is essential for the progression of intestinal divisions. Cell Cycle. 15, 654-666.

Leung, C.T., and Brugge, J.S. (2012). Outgrowth of single oncogene-expressing cells from suppressive epithelial environments. Nature. 482, 410-413.

Mailand, N., Podtelejnikov, A. V., Groth, A., Mann, M., Bartek, J., and Lukas, J. (2002). Regulation of G2/M events by Cdc25A through phosphorylationdependent modulation of its stability. EMBO J. 21, 5911-5920.

Marshall, T.W., Lloyd, I.E., Delalande, J.M., Näthke, I., and Rosenblatt, J. (2011). The tumor suppressor adenomatous polyposis coli controls the direction in which a cell extrudes from an epithelium. Mol. Biol. Cell. 22, 3962-3670.

McMahon, L., Legouis, R., Vonesch, J.L., and Labouesse, M. (2001). Assembly of $C$. elegans apical junctions involves positioning and compaction by LET-413 and protein aggregation by the MAGUK protein DLG-1. J. Cell Sci. 114, 2265-2277.

Mello, C.C., Kramer, J.M., Stinchcomb, D., and Ambros, V. (1991). Efficient gene transfer in C. elegans: extrachromosomal maintenance and integration of transforming sequences. EMBO J. 10, 3959-3970. 
1198

1199

1200

1201

1202

1203

1204

1205

1206

1207

1208

1209

1210

1211

1212

1213

1214

1215

1216

1217

1218

1219

1220

1221

1222

1223

1224

1225

1226

1227

1228

1229

1230

1231

1232

1233

1234

1235

1236

1237

1238

1239

1240

1241

1242

Ohsawa, S., Vaughen, J. and Igaki, T. (2018). Cell extrusion: a stressresponsive force for good or evil in epithelial homeostasis. Dev. Cell 44, 284-296.

Ossareh-Nazari, B., Katsiarimpa, A., Merlet, J., and Pintard, L. (2016). RNAiBased suppressor screens reveal genetic interactions between the CRL2LRR-1 E3-ligase and the dna replication machinery in Caenorhabditis elegans. G3 Genes, Genomes, Genet. 6, 3431-3442.

Otto, T., and Sicinski, P. (2017). Cell cycle proteins as promising targets in cancer therapy. Nat. Rev. Cancer. 17, 93-115.

Rosenblatt, J., Raff, M.C., and Cramer, L.P. (2001). An epithelial cell destined for apoptosis signals its neighbors to extrude it by an actin- and myosindependent mechanism. Curr. Biol. 11, 1847-1857.

Rual, J.F., Ceron, J., Koreth, J., Hao, T., Nicot, A.S., Hirozane-Kishikawa, T., Vandenhaute, J., Orkin, S.H., Hill, D.E., van den Heuvel, S., and Vidal, M. (2004). Toward improving Caenorhabditis elegans phenome mapping with an ORFeome-based RNAi library. Genome Res. 14, 2162-2168.

Sakaue-Sawano, A., Kurokawa, H., Morimura, T., Hanyu, A., Hama, H., Osawa, H., Kashiwagi, S., Fukami, K., Miyata, T., Miyoshi, H., Imamura, T., Ogawa, M., Masai, H., and Miyawaki, A. (2008). Visualizing spatiotemporal dynamics of multicellular cell-cycle progression. Cell. 132, 487-498.

Saw, T.B., Doostmohammadi, A., Nier, V., Kocgozlu, L., Thampi, S., Toyama, Y., Marcq, P., Lim, C.T., Yeomans, J.M., and Ladoux, B. (2017). Topological defects in epithelia govern cell death and extrusion. Nature. 544, 212-216.

Schindelin, J., Arganda-Carreras, I., Frise, E., Kaynig, V., Longair, M., Pietzsch, T., Preibisch, S., Rueden, C., Saalfeld, S., Schmid, B., Tinevez, J.Y., White, D.J., Hartenstein, V., Eliceiri, K., Tomancak, P., and Cardona, A. (2012). Fiji: An open-source platform for biological-image analysis. Nat. Methods. 9, 676-682.

Slattum, G., Gu, Y., Sabbadini, R. and Rosenblatt, J. (2014). Autophagy in oncogenic $\mathrm{K}$-Ras promotes basal extrusion of epithelial cells by degrading S1P. Curr. Biol. 24, 19-28.

Spencer, S.L., Cappell, S.D., Tsai, F.C., Overton, K.W., Wang, C.L., and Meyer, T. (2013). The proliferation-quiescence decision is controlled by a bifurcation in CDK2 activity at mitotic exit. Cell 155, 369-383. 
1243

1244

1245

1246

1247

1248

1249

1250

1251

1252

1253

1254

1255

1256

1257

1258

1259

1260

1261

1262

1263

1264

1265

1266

1267

1268

1269

1270

1271

1272

1273

1274

1275

1276

1277

1278

1279

1280

1281

1282

1283

1284

1285

1286

1287

1288

Stevens, H., Williams, A.B., and Michael, W.M. (2016). Cell-type specific responses to DNA replication stress in early C. elegans embryos. PLoS One 11, e0164601.

Streichan, S.J., Hoerner, C.R., Schneidt, T., Holzer, D., and Hufnagel, L. (2014). Spatial constraints control cell proliferation in tissues. Proc. Natl. Acad. Sci. 111, 5586-5591.

Sulston, J.E., Schierenberg, E., White, J.G., and Thomson, J.N. (1983). The embryonic cell lineage of the nematode Caenorhabditis elegans. Dev Biol. 100, 64-119.

Teuliere, J., Cordes, S., Singhvi, A., Talavera, K., and Garriga, G. (2014). Asymmetric neuroblast divisions producing apoptotic cells require the cytohesin GRP-1 in Caenorhabditis elegans. Genetics. 198, 229-247.

Timson, J. (1975). Hydroxyurea. Mutat. Res. 32, 115-132.

van den Heuvel, S. (2005). Cell cycle regulation. WormBook, ed. The C. elegans Research Community WormBook, WormBook.

van Rijnberk, L.M., van der Horst, S.E., van den Heuvel, S. and Ruijtenberg, S. (2017). A dual transcriptional reporter and CDK-activity sensor marks cell cycle entry and progression in C. elegans. PLoS One 12, e0171600.

Wallenfang, M.R., and Seydoux, G. (2002). cdk-7 is required for mRNA transcription and cell cycle progression in Caenorhabditis elegans embryos. Proc. Natl. Acad. Sci. U. S. A. 99, 5527-5532.

Wernike, D., Chen, Y., Mastronardi, K., Makil, N., and Piekny, A. (2016). Mechanical forces drive neuroblast morphogenesis and are required for epidermal closure. Dev. Biol. 412, 261-277.

Wu, S. K., Gomez, G. A., Michael, M., Verma, S., Cox, H. L., Lefevre, J. G., Parton, R. G., Hamilton, N. A., Neufeld, Z. and Yap, A. S. (2014). Cortical F-actin stabilization generates apical-lateral patterns of junctional contractility that integrate cells into epithelia. Nat. Cell Biol. 16, 167-178.

Xiao, Z., Chen, Z., Gunasekera, A.H., Sowin, T.J., Rosenberg, S.H., Fesik, S., and Zhang, H. (2003). Chk1 mediates S and G2 arrests through Cdc25A degradation in response to DNA-damaging agents. J. Biol. Chem. 278, 21767-21773.

Yazinski, S.A., and Zou, L. (2016). Functions, regulation, and therapeutic implications of the ATR checkpoint pathway. Annu. Rev. Genet. 50, 155173. 
Yeong, F.M. (2004). Anaphase-promoting complex in Caenorhabditis elegans.

1291

1292

1293

1294

1295

1296

1297

1298

1299 Mol. Cell. Biol. 24, 2215-2225.

1300

1301

1302

1303

Zeman, M.K., and Cimprich, K.A. (2014). Causes and consequences of replication stress. Nat. Cell Biol. 16, 2-9.

Zerjatke, T., Gak, I.A., Kirova, D., Fuhrmann, M., Daniel, K., Gonciarz, M., Müller, D., Glauche, I., and Mansfeld, J. (2017). Quantitative cell cycle analysis based on an endogenous all-in-one reporter for cell tracking and classification. Cell Rep. 19, 1953-1966.

1304

Ziel, J.W., Hagedorn, E.J., Audhya, A., and Sherwood, D.R. (2009). UNC-6 (netrin) orients the invasive membrane of the anchor cell in C. elegans. Nat. Cell Biol. 11, 183-189. 